\title{
Geohydrology of the Eastern Part of Pahute Mesa, Nevada Test Site, Nye County, Nevada
}

G E OLOG I CAL S URVEY PROFESSIONALA PAER 712 - B

Prepared on behalf of the U.S. Atomic Energy Commission

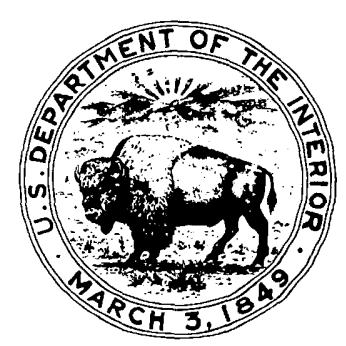




\section{Geohydrology of the Eastern Part of Pahute Mesa, Nevada Test Site, Nye County, Nevada}

By RICHARD K. BLANKENNAGEL and J. E. WEIR, JR.

\section{HYDROLOGY OF NUCLEAR TEST SITES}

GEOLOGICAL SURVEY PROFESSIONAL PAPER 712 - B

Prepared on behalf of the

U.S. Atomic Energy Commission

Description of hydraulic testing in deep drill holes and of ground-water characteristics in the

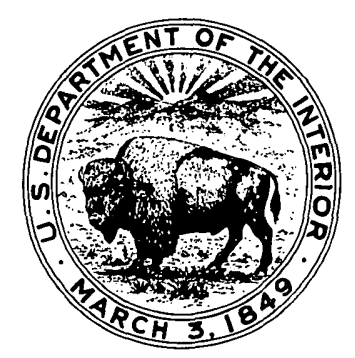

Pahute Mesa area 


\section{UNITED STATES DEPARTMENT OF THE INTERIOR}

ROGERS C. B. MORTON, Secretary

GEOLOGICAL SURVEY

V. E. McKelvey, Director

Library of Congress catalog-card No. 72-600384

For sale by the Superintendent of Documents, U.S. Government Printing Office Washington, D.C. 20402 - Price $\$ 1.75$ domestic postpaid or $\$ 1.50$ GPO Bookstore Stock Number 2401-00303 


\section{CONTENTS}

Abstract.

Introduction

Purpose and scope

Previous hydrologic investigations.

Acknowledgments

Geologic setting.

Stratigraphic units and their hydrologic significance...

Structure.

Aquifers and aquitards

Rhyolitic lava flows.

Characteristics of surface exposures

Characteristics based on cores, geophysical logs, and drilling records.

Characteristics based on hydraulic tests

Welded tuffs..

Characteristics of surface exposures.

Characteristics based on cores, geophysical $\operatorname{logs}$ and drilling records.

Characteristics based on hydraulic tests.............

Ash-fall tuffs, nonwelded or slightly welded ashflow tuffs, and tuffaceous sediments.

Characteristics of surface exposures.

Characteristics based on cores, geophysical logs, and drilling records.
Page

B1 Aquifers and aquitards-Continued

1 Ash-fall tuffs, nonwelded or slightly welded ash-flow

2 tuffs, and tuffaceous sediments-Continued

3 Characteristics based on hydraulic tests.............. B17

3 Regional movement of ground water................................ 17

3 Estimates of underflow beneath Pahute Mesa........... 19

Estimated annual recharge from precipitation and underflow.

Estimated annual discharge.

Local movement of ground water......................................... 21

Head changes in drill holes........................................ 21

Relation between subsurface temperatures and flow patterns.

Water-level contour map..

Ground-water velocity.

Chemical quality of water

Water chemistry and regional movement of ground water.

Engineering hydrology

Rock media best suited for chamber construction...... 30

Water inflow to chambers............................................. 30

Water supply................................................................. 31

Areas favorable for drilling water-supply wells 31

Summary and conclusions.................................................... 32

16 References...................................................................... 34

\section{ILLUSTRATIONS}

[Plates are in pocket]

Plate 1. Water-level contour map showing faults and caldera boundaries, eastern Pahute Mesa.

2. Generalized geologic sections across Silent Canyon caldera, eastern Pahute Mesa.

3. Map showing direction of ground-water movement from eastern Pahute Mesa toward discharge areas in Oasis Valley and Amargosa Desert.

Figure 1. Index map of the report area and locations of exploratory and large-diameter emplacement holes.

2. Bouguer gravity map of Silent Canyon caldera.

3. Map showing percentage of rock types with resistivities greater than $225 \mathrm{ohms}-\mathrm{m}^{2} / \mathrm{m}$ on 16 -inch normal curve of electric log (rhyolite and densely welded tuff) in upper 2,000 feet of saturated zone.

4-7. Graphs showing:

4. Relative specific capacity of the major rock types within the saturated zone

5. Drawdown during 28-hour pumping test of hole UE-19h, August 4-5, 1965

6. Drawdown during 29-hour pumping test of hole U-20a-2, February 10-12, 1965

7. Drawdown during a pumping test of hole UE-20e-1, June 4-5, 1964 ...

8. Fence diagram showing resistivity of rocks in upper 2,000 feet of saturated zone

9. Map showing ranges of transmissivity.

10. Map showing head changes with depth in exploratory test holes..

11. Water-chemistry map...

12. Graph showing inflow through small-diameter holes drilled into prospective chamber zones U-20f and U-20c

Page B2 


\section{TABLES}

TABLE 1. Summary of lithology and thickness of the major Cenozoic rock units, Pahute Mesa, Nevada Test Site..........

2. Resistivity calculations from 16 -inch normal curve on electric logs made in upper 2,000 feet of zone of saturation in exploratory holes, Pahute Mesa.

3. Results from pumping tests of exploratory holes, Pahute Mesa.

4. Summary of porosity and fracture frequency in core samples of welded tuffs.

5. Summary of porosity and fracture frequency in core samples of ash-fall and nonwelded ash-flow tuffs

6. Estimated average annual ground-water potential recharge from precipitation at Pahute Mesa and Rainier Mesa...

7. Head changes with depth in exploratory holes, Pahute Mesa...

8. Bottom-hole temperatures and thermal gradients in exploratory holes, Pahute Mesa.

9. Estimated ground-water velocity in volcanic rocks beneath Pahute Mesa.

10. Selected chemical analyses of water from exploratory holes and chambers, Pahute Mesa...................

11. Relative abundance of principal ions in selected ground-water samples from Pahute Mesa

12. Water-inflow, construction, and hydraulic-testing data for mined emplacement chambers within the saturated zone, Pahute Mesa. 


\title{
GEOHYDROLOGY OF THE EASTERN PART OF PAHUTE MESA, NEVADA TEST SITE, NYE COUNTY, NEVADA
}

\author{
By Richard K. Blankennagel and J. E. Weir, Jr.
}

\section{ABSTRACT}

A deep structural depression, the Silent Canyon caldera, underlies the eastern part of Pahute Mesa, Nye County, Nev. The caldera is elliptical in plan and measures about 11 by 14 miles; the greater axis trends in a north-northeast direction. Exploratory drilling revealed a Tertiary volcanic section of ash-flow and ash-fall tuffs and rhyolitic lava flows which attained thicknesses in excess of 13,686 feet. Hydraulic tests made in deep drill holes indicated that these volcanic rocks are capable of transmitting water and that measurable permeability occurs at depths greater than 3,500 feet below the top of the saturated zone.

Most movement of ground water beneath the mesa occurs through interconnecting fault and joint systems. Fractures are more common in rhyolitic lava flows and in densely welded ash-flow tuffs, and these fractures have a greater tendency to remain open than do those in ash-fall and nonwelded ash-flow tuffs. The yield of water to wells from intervals of ash-fall and nonwelded ash-flow tuffs, particularly those that are zeolitized or argillized, is low. Hence, these rocks are considered the best media for mining of underground chambers in the saturated zone.

In the Silent Canyon caldera, depth to water ranges from about 1,952 feet (alt $4,164 \mathrm{ft}$ ) in the western part to 2,350 feet (alt 4,685 ft) in the eastern part. In the extreme northwestern part of the Nevada Test Site, outside the caldera, the depth to water is about 850 feet (alt 4,700 ft). Stable and declining head potentials occur with depth in all but one of the holes drilled in the eastern part of the report area; variable heads in the upper 1,500 feet of the saturated zone and then increasing heads to total drilled depth occur in holes drilled in the western part. Pumping tests indicate that transmissivities range from 1,400 to 140,000 gallons per day per foot. The greatest transmissivities occur in holes drilled along the east margin of the caldera, where the principal rock type in the saturated zone is rhyolite. Water derived from drill holes at Pahute Mesa is sodium potassium type. These chemical constituents comprised over 90 percent of the total cations in more than half the samples that were analyzed.

Ground water beneath Pahute Mesa moves southwestward and southward toward the Amargosa Desert through Oasis Valley, Crater Flat, and western Jackass Flats. The flow, across a 15-mile underflow strip which extends from the hydraulic barrier on the west to the ground-water divide on the east, is estimated to be 8,000 acre-feet per year. Owing to the difficulty in obtaining accurate porosity data, estimates of ground-water velocity vary as much as two orders of magnitude -5 to 250 feet per year. Based on the assumption that most ground-water movement occurs along interconnected fractures and that some movement occurs through interstices, a reasonable estimate of velocity is less than 15 feet per year.

\section{INTRODUCTION}

Geologic and hydrologic studies in the Pahute Mesa area were intensified in 1962 by the U.S. Geological Survey on behalf of the U.S. Atomic Energy Commission. The objective of these studies was to assist the Commission in selecting an area suitable for underground testing of larger nuclear devices at depths greater than were feasible within the then-existing limits of the Nevada Test Site. With the completion of hole PM-1 in 1963, the decision was made to add eastern Pahute Mesa to the test site, and the land was obtained from the U.S. Bureau of Land Management and the U.S. Air Force.

The Pahute Mesa area is about 130 miles northwest of Las Vegas, Nev., in Nye County, in the northwestern part of the Atomic Energy Commission's Nevada Test Site. (See fig. 1.) It is an elevated plateau of about 200 square miles with relatively gentle relief. Altitude ranges from 5,500 to more than 7,000 feet.

The geological studies revealed a sequence of flatlying volcanic rocks, and data from a gravity survey indicated a deep structural basin beneath the eastern part of the mesa. An exploratory hole, PM-1 (fig. 1) was drilled in May 1963 in the center of the structural basin to a depth of 7,500 feet. A thick sequence of zeolitized bedded tuffs having low transmissivities, considered excellent test media, was penetrated in the hole. A deep water table, more than 2,000 feet below land surface, contributed to the favorability of the area. From 1963 through 1968, 19 exploratory holes were drilled in and near the eastern part of Pahute Mesa. This extensive 


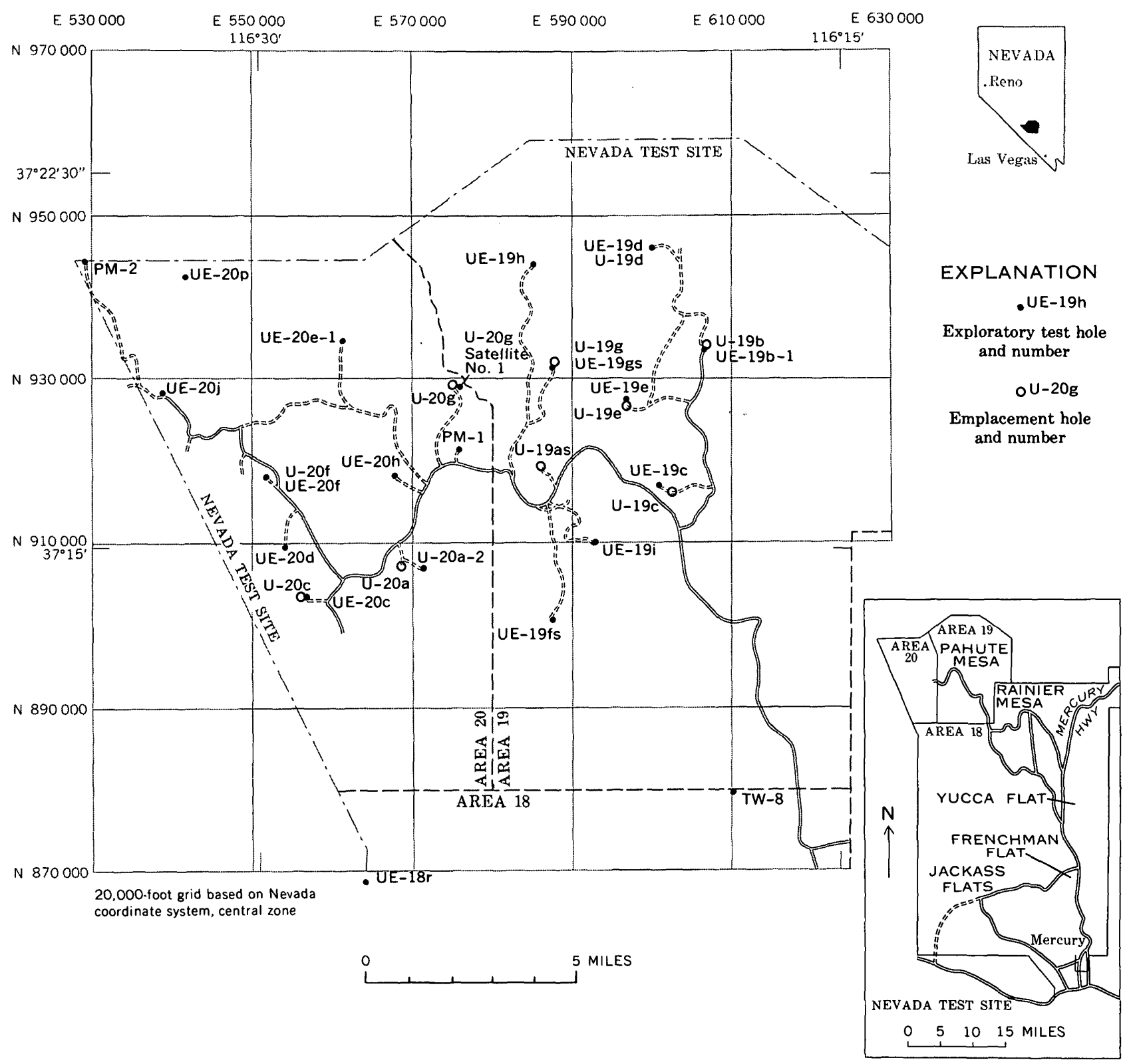

FIGURE 1. - Index map of the report area and locations of exploratory and large-diameter emplacement holes.

drilling program yielded data for evaluation of the subsurface geologic and hydrologic environment which is summarized in this report.

\section{PURPOSE AND SCOPE}

The purpose of the hydrologic investigation was to determine the water-yielding potential of volcanic rock strata in each exploratory or nuclear emplacement drill hole and, in particular, of those strata that were most favorable for construction of chambers. Many of the proposed tests require mined chambers in the saturated zone. To insure safety of miners, these chambers must be constructed in intervals of rock having low permeability. The longrange purpose of the investigation included deter- mination of (1) the distribution and hydraulic characteristics of the principal rock types; (2) local and regional directions of ground-water movement, including possible areas of recharge and discharge; (3) ground-water velocities; and (4) areas favorable for development of water supplies.

Hydraulic data, obtained from each exploratory or emplacement hole, and geological, geophysical, and geochemical data have been synthesized to present herein the current status of geohydrologic interpretations. The complexity of the geologic and hydrologic data offered considerable latitude for interpretation of underflow beneath Pahute Mesa, ground-water velocity ranges, and discharge in nearby areas. 


\section{PREVIOUS HYDROLOGIC INVESTIGATIONS}

Hydraulic tests at Pahute Mesa began in 1963 with those made in the PM-1 exploratory drill hole. At that time, a wealth of information on testing techniques and on hydrology of volcanic rock strata was available from previous investigations in other areas at the Nevada Test Site. These investigations were divided into three phases (Winograd and others, 1971). To some extent, the investigations conducted in each phase were designed to fulfill the immediate needs of the Atomic Energy Commission in an expeditious manner. Briefly, the first phase (1957-59) included (1) the collection of hydrologic data from all existing wells and springs at or near the Nevada Test Site and (2) detailed studies of the hydrology of the tuff underlying Rainier Mesa through observations made in tunnels and shafts driven into the east face of Rainier Mesa. The second phase (1960-61) consisted mostly of the study of the hydrology of Yucca Flat, and the third phase (1962-64) involved collection of data from test holes drilled at Yucca Flat, Frenchman Flat, Jackass Flats, and the area adjacent to the test site south and southeast of Mercury.

In addition to the reports prepared on behalf of the Atomic Energy Commission, several reports prepared cooperatively by the Geological Survey and the State of Nevada, Department of Conservation and Natural Resources, Carson City, were of value during preparation of this report.

\section{ACKNOWLEDGMENTS}

The writers express appreciation to the U.S. Atomic Energy Commission for the support given to the project. Particular acknowledgment is given to those members of the Office of Effects Evaluation and the Office of Engineering and Logistics, Nevada Operations Office, Las Vegas, Nev., who were directly involved in overall coordination of the project.

Interpretations of the geological structure and stratigraphy used in the report were developed by P. P. Orkild and other geologists of the U.S. Geological Survey.

Finally, field assistance was rendered by many individuals employed by contractors to the Atomic Energy Commission, the scientific laboratories who conduct the nuclear tests, and other firms.

\section{GEOLOGIC SETTING}

Gravity data indicated the existence of a deep structural depression under the eastern part of Pahute Mesa. (See fig. 2.) Subsequent exploratory drilling confirmed this interpretation and revealed a Tertiary volcanic section of ash-flow and ash-fall tuffs and lava flows at least 13,686 feet thick. This structural depression has been identified as the product of cauldron subsidence and named the Silent Canyon caldera (Noble and others, 1968; Orkild and others, 1968). The caldera, which occupies about 90 percent of the report area, is elliptical in plan, measuring approximately 11 by 14 miles; the greater axis trends north-northeast, roughly parallel to the strike of basin-and-range faulting.

The Silent Canyon caldera is masked by younger volcanic rocks except along the east boundary, where the wall of the caldera is exposed in some localities. Steepening isogals on the Bouguer gravity map and geological correlations based on subsurface data have approximately located the boundary or ring faults of the caldera. The southern part of the Silent Canyon caldera is intersected by the Timber Mountain caldera (Byers and others, 1968); thus, the boundary in that area is more complex.

No pre-Tertiary rocks were penetrated in exploratory holes drilled within the caldera or in the immediate vicinity outside the caldera. Paleozoic rocks are exposed about 10 miles north and 8 miles eastsoutheast of the caldera. A small stock of plutonic rock of Mesozoic age is exposed 5 miles east of the caldera (Orkild and others, 1968).

\section{STRATIGRAPHIC UNITS AND THEIR HYDROLOGIC} SIGNIFICANCE

The rocks which were emplaced during and after the collapse of the Silent Canyon caldera form key hydrogeologic units. Beyond the eastern, northern, and western limits of the caldera, precaldera rocks locally are aquifers. Within the caldera, the precaldera rocks are buried at such great depths they have little hydrologic significance.

For hydrologic and engineering purposes, the rocks are grouped into precaldera, intracaldera, and postcaldera rocks. A summary of the rock units is shown in table 1.

In the eastern part of the Silent Canyon caldera, fractured rhyolites and welded tuffs assigned to the lava and tuff of Deadhorse Flat are the only aquifers of consequence. In general, the greatest values of relative specific capacity were measured in intervals of fractured rhyolitic lavas in the upper 2,000 feet of the saturated zone. In holes drilled near the east margin of the Silent Canyon caldera, rhyolitic lava flows comprise almost 100 percent of the rock in the upper 2,000 feet of the saturated zone. (See fig. 3.)

Rhyolites, vitrophyres, and welded tuffs of the tuffs and rhyolites of Area 20 that are fractured and faulted constitute the significant aquifers in the western and central parts of the Silent Canyon 


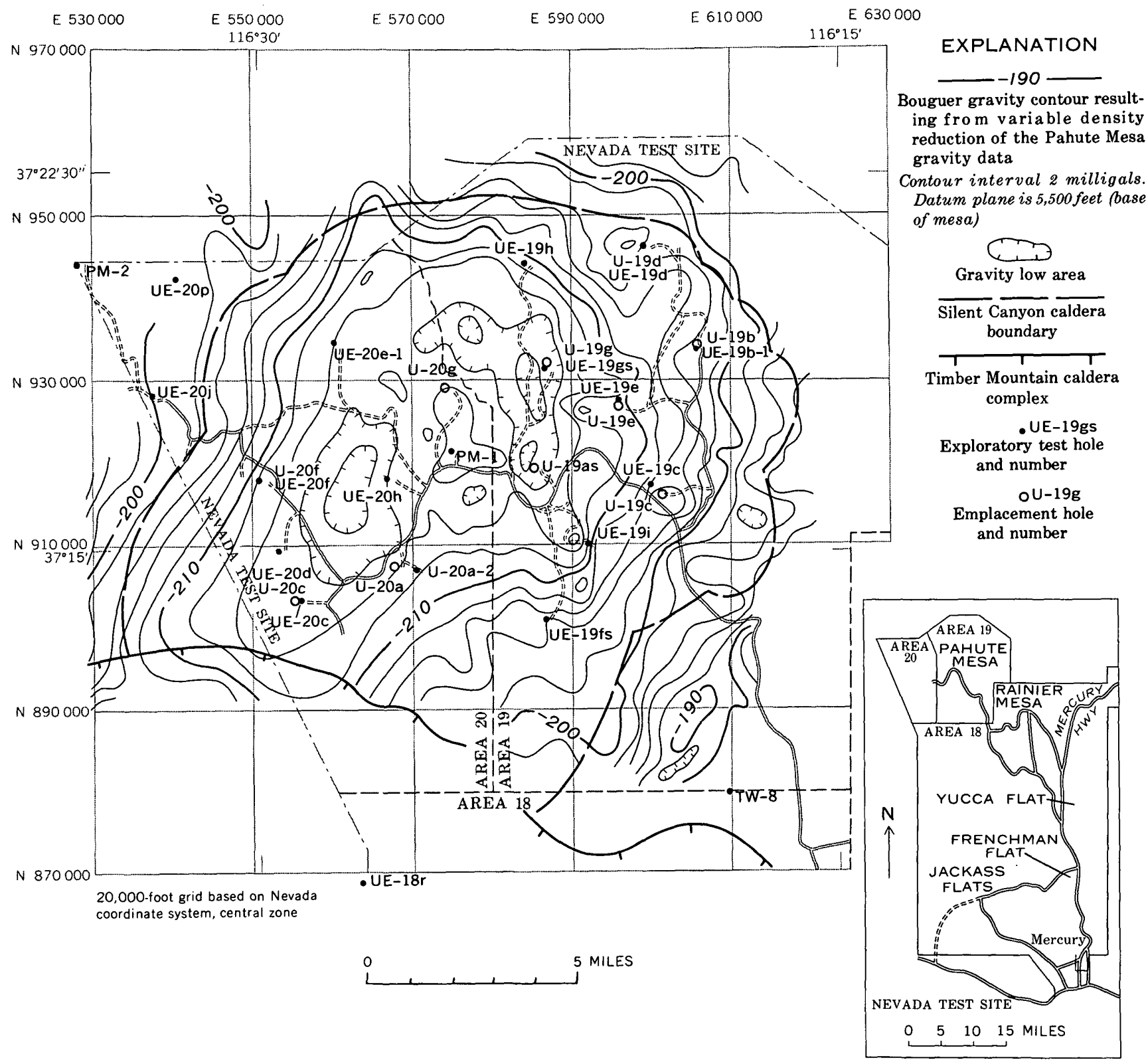

Figure 2. - Bouguer gravity map of Silent Canyon caldera.

caldera. With the exception of a concentration of rhyolitic lava flows in the southwestern part of the caldera, ash-fall and ash-flow tuffs are predominant in this intracaldera unit. These tuffs are mostly zeolitized and are relatively impermeable; fractures and faults in these zeolitized rocks are generally resealed.

\section{STRUCTURE}

The major structure in the report area is the deep depression that has been designated the Silent Canyon caldera. The features of this caldera include (1) a ring-fracture zone with vertical displacements ranging from 7,000 feet on the west to about 5,000 feet on the northeast, (2) a shallow broad subarcuate basin in the eastern and northeastern parts, (3) a north-northeast-trending deep basin in the western part, and (4) a horstlike feature in the center of the caldera, between the intracaldera deeps. Structure in the southern part of the caldera is complicated by intersection with the ring-fracture zone of the Timber Mountain caldera. The principal structures are shown in figure 2 and on plates 1 and 2.

Basin-and-range faulting was active throughout the evolution of the Silent Canyon caldera and probably during deposition of the precaldera rocks. Most of the basin-and-range faults are expressed at the surface; however, in the western part, some faults are masked by the Thirsty Canyon Tuff, the youngest postcaldera formation (Orkild and others, 1968). Most of the faults strike north-northeast and north; 
PART OF PAHUTE MESA, NEVADA TEST SITE, NEVADA

TABLE 1. - Summary of lithology and thickness of the major Cenozoic rock units at Pahute Mesa, Nevada Test Site [After Orkild, Sargent, and Snyder (1969). Local units not formally named have been largely excluded from this table]

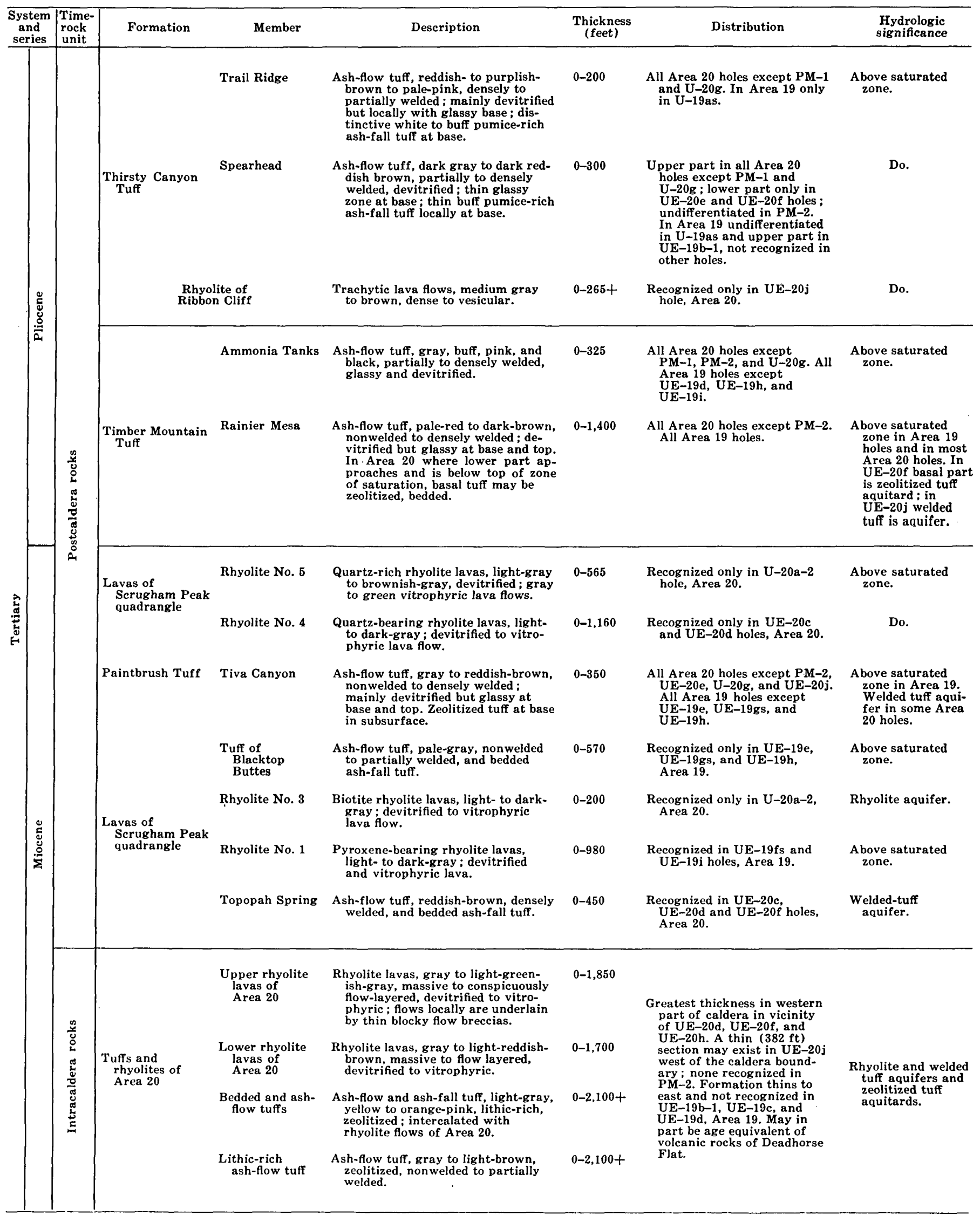


TABLE 1. - Summary of lithology and thickness of the major Cenozoic rock units at Pahute Mesa, Nevada Test Site - Continued

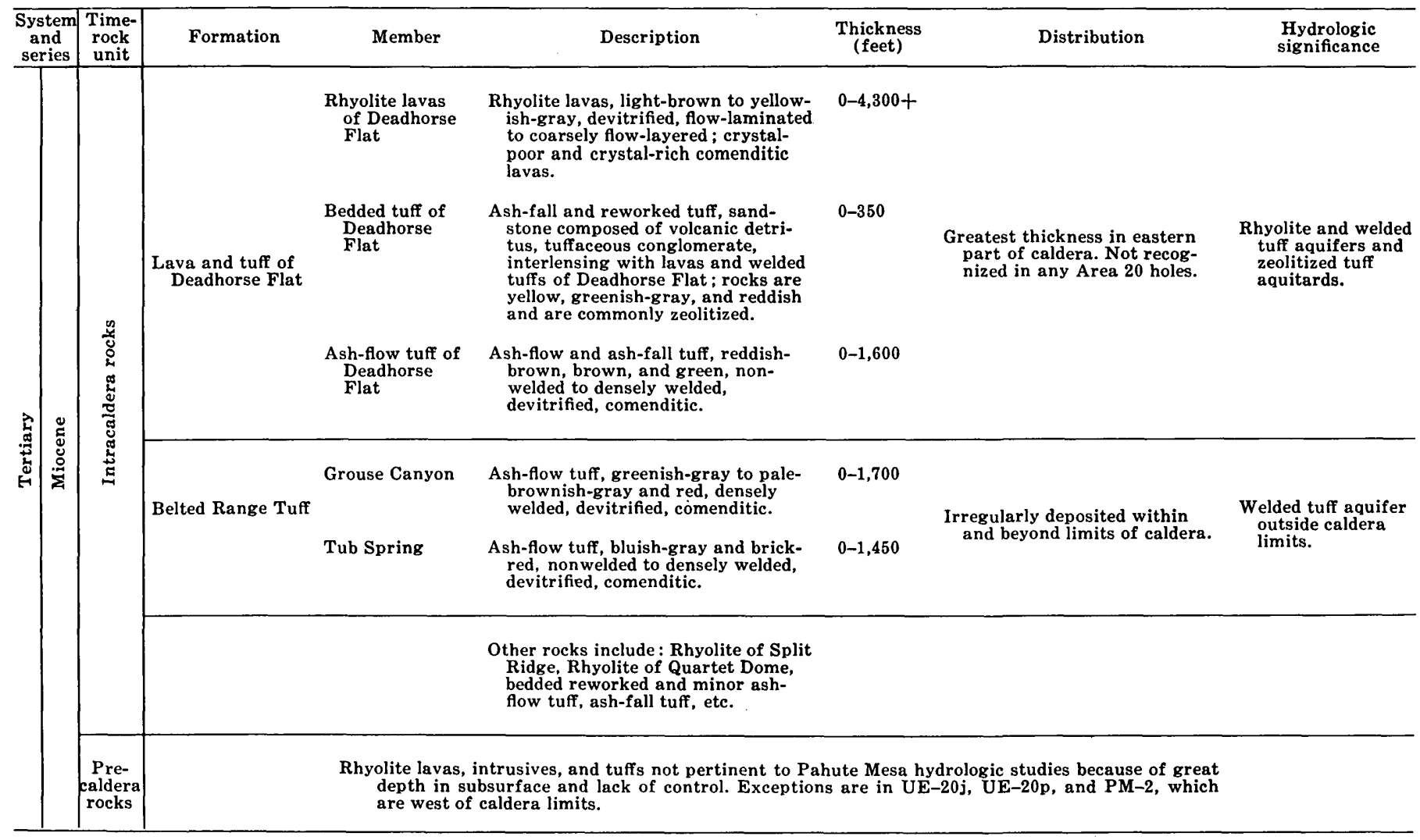

displacements range from a few feet to about 800 feet; most faults are downthrown to the west. Major faults near the east margin of the caldera provided the fissures or vents for the extensive rhyolitic lava flows that flooded the eastern part of the caldera. Secondary fault systems, stemming from the primary basin-and-range fault system, trend in various directions and have only minor displacements.

\section{AQUIFERS AND AQUITARDS}

The rock units at Pahute Mesa that afford positive stratigraphic control on the surface and in the subsurface are the widespread ash-flow sheets of the Belted Range Tuff, which probably are contemporaneous with initial caldera collapse, and the major ash-flows of the Timber Mountain Tuff and Paintbrush Tuff, which are postcaldera in age. Heterogeneous intracaldera rocks occur between these widespread ash-flow sheets within the saturated zone under Pahute Mesa. These intracaldera rocks include ash-fall and ash-flow tuffs and rhyolitic lava flows which emanated from fissures within the subsiding caldera and from nearby volcanic centers. The vertical and horizontal distribution of these intracaldera ash-fall and ash-flow tuffs and lava flows over short distances is variable. These abrupt changes in rock types make subsurface correlations between test holes extremely difficult.
Interstitial permeability, although small, allows some ground-water movement; most of the movement under Pahute Mesa occurs in fractures. In a widespread sheet of welded tuff there may be interconnected fractures over an area large enough to justify classification of a formation or member as an aquifer. Such welded-tuff units as the Rainier Mesa Member of the Timber Mountain Tuff and the Topopah Spring Member of the Paintbrush Tuff are aquifers where saturated. Fractures are common in some flows and absent in others. Factors controlling location of fractures appear to have been mode of tuff emplacement, cooling history, and proximity to faults. The depth at which intervals of high permeability may be penetrated in relatively closely spaced drill holes cannot be predicted. The combined thickness of intervals with measurable fracture permeability generally ranges from 3 to 10 percent of the total rock section penetrated in the saturated zone.

The complex structure within the caldera, and especially the high incidence of fractures, often results in high measured water yields from rocks and members that normally are classed as aquitards. (A specific capacity of $0.1 \mathrm{gpm}$ (gallon(s) per minute) per foot of drawdown per 1,000 feet of saturated rock is the arbitrary distinction between an aquifer and aquitard.) The Tub Spring and 


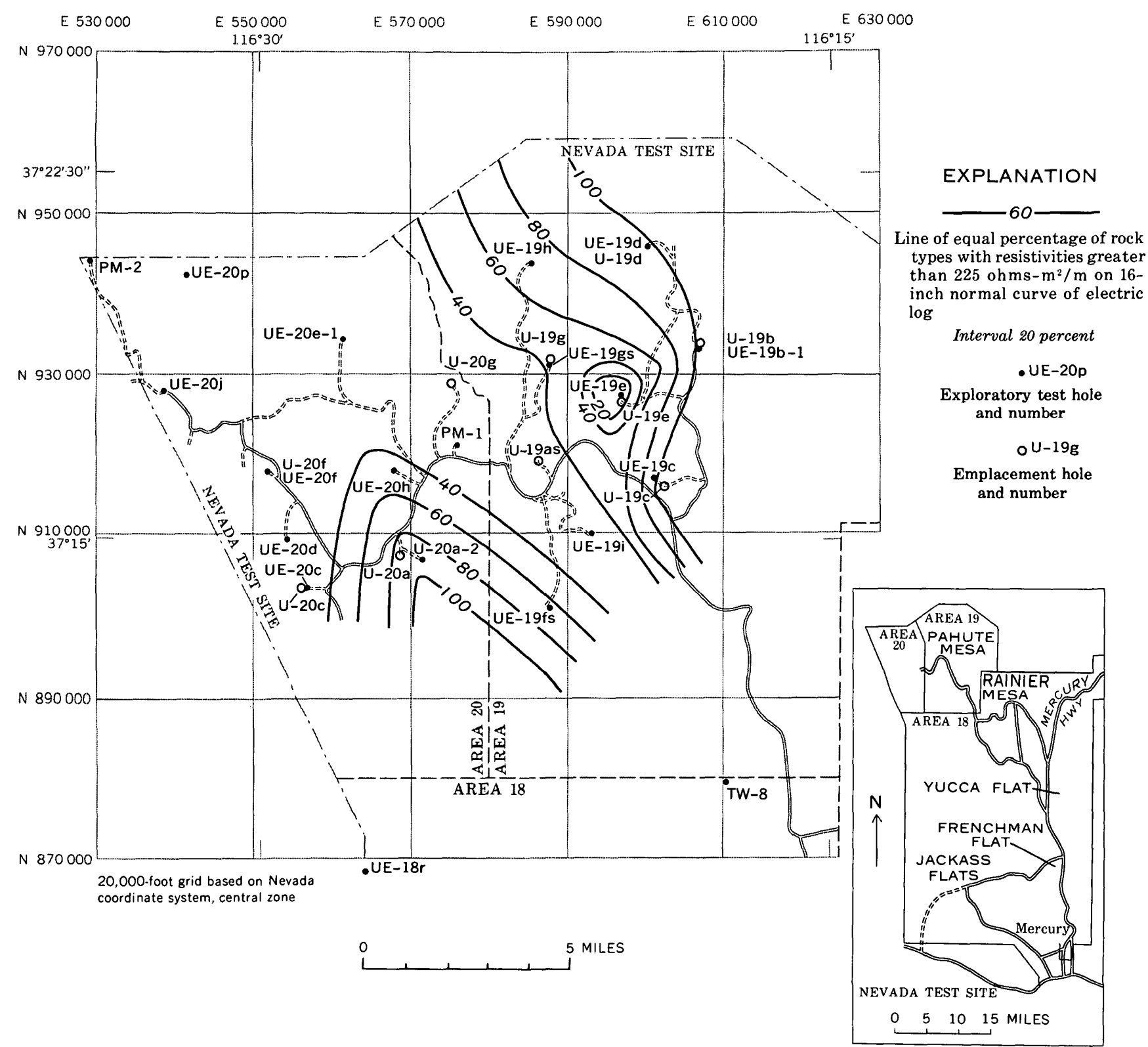

Figure 3. - Percentages of rock types with resistivities greater than $225 \mathrm{ohms}-\mathrm{m}^{2} / \mathrm{m}$ on 16 -inch normal curve of electric $\log$ (rhyolite and densely welded tuff) in upper 2,000 feet of saturated zone.

Grouse Canyon Members of the Belted Range Tuff are aquitards throughout most of the Nevada Test Site (Winograd and others, 1971), and they are nearly impervious in at least three drill holes at Pahute Mesa. In the UE-19h and UE-20j drill holes, however, the Tub Spring is permeable; and in the UE-20j drill hole the Grouse Canyon is permeable. The UE-20j hole was drilled near the ring-fracture zone of the caldera, and the UE-19h hole was drilled in a faulted area.

The results of hydraulic tests of 150 - to 200 -foot intervals in the various drill holes are summarized by yield and rock type in figure 4 . Of the 297 tests that are plotted, 102 of the drill-stem tests were made in rhyolitic lavas, including rhyolite breccia and vitrophyre; 41 were made in welded tuff and 54 in bedded and zeolitized tuff. The intervals isolated by straddle packers during some of these tests unavoidably included two of these rock types, in which case the principal type was considered as representative of the entire interval tested unless radioactive-tracer or other geophysical logging surveys indicated otherwise.

In general, the lowest permeabilities were found where the principal rock was zeolitized tuff. Rhyolitic lavas, including rhyolite breccia and vitrophyre, 
yielded water most freely in all drill holes; however, some of the rhyolitic lavas are relatively impermeable. The welded tuff generally was more permeable than the zeolitized bedded tuff.

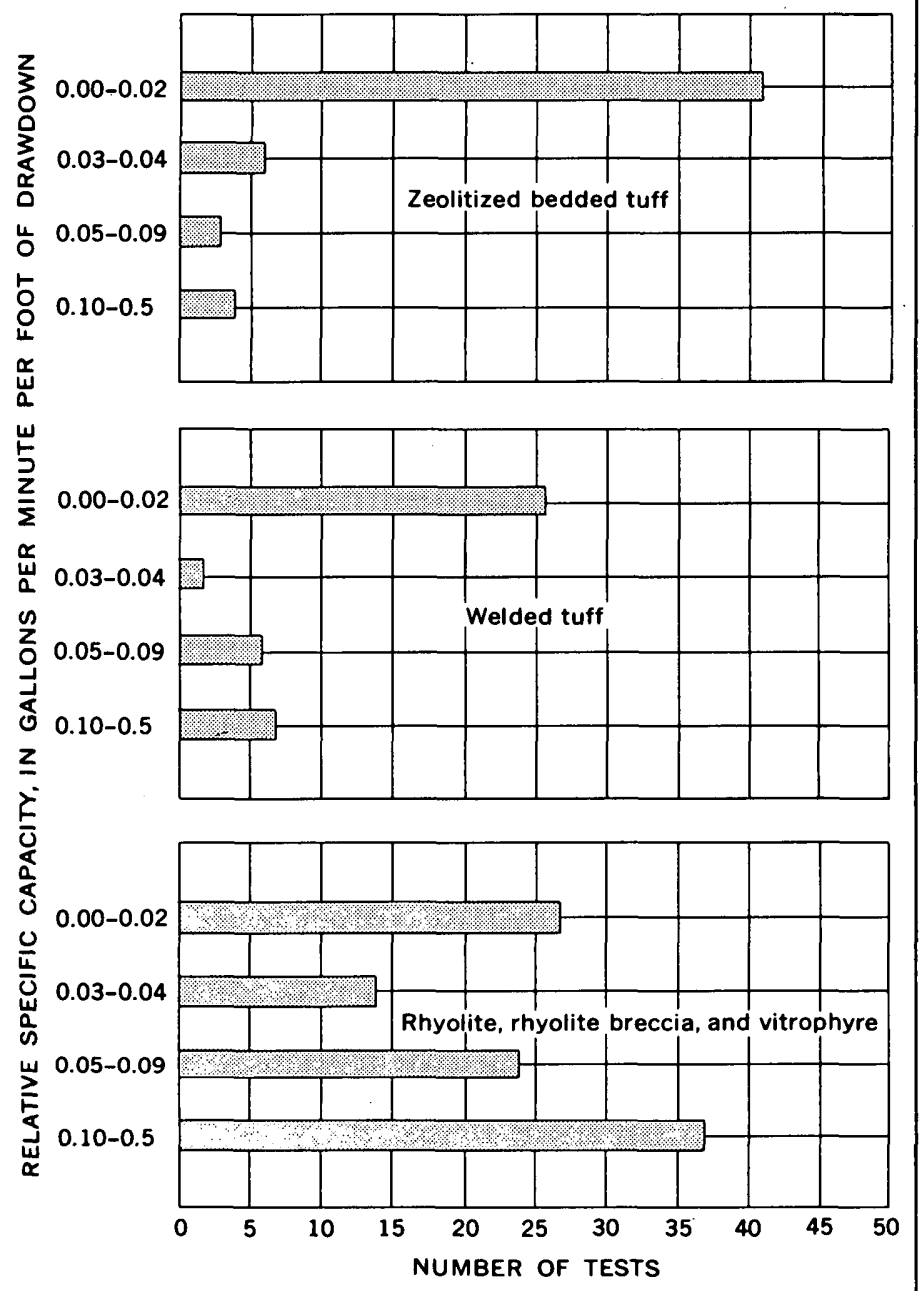

Figure 4. - Relative specific capacity (150- to 200-ft intervals) of the major rock types within the saturated zone.

\section{RHYOLITIC LAVA FLOWS}

Rhyolitic lava flows have a wide range in wateryield potential. Whereas some of these flows are nearly impervious, some others have highly fractured or brecciated zones that may yield as much as $50 \mathrm{gpm}$ per foot of drawdown.

Eruption of lava flows into the subsiding caldera was fairly continuous in the eastern part and, later, sporadic in the western part. Depending on viscosity and topography, the flows spread for distances of several miles or formed more limited thick flows or steep-sided domes. The thickness of individual flows penetrated in wells ranged from a few feet to more than 1,000 feet.

Both vapor-phase cavities alined along flowbanding and interstitial spaces in rubble breccia con- tribute locally to ground-water movement in lava flows. Most ground-water flow, however, occurs along faults and interconnected vertical and horizontal fracture systems that developed during cooling and shrinkage of the lava flow. Fracture systems which are highly interconnected typically occur along the outer margins of lava flows. Highly impermeable intervals often occur in the central crystalline parts of very thick flows of highly viscous lava. A series of overlapping flows, with little interruption between flows, would result in slower cooling of a large mass of lava and, hence, in thick intervals having few fractures and low permeability.

\section{CHARACTERISTICS OF SURFACE EXPOSURES}

Surface exposures of rhyolitic lava flows at and near Pahute Mesa occur in postcaldera rocks above the saturated zone. The vertical structural zonation in widely separated flows is quite similar, and probably lavas in the subsurface also have similar zonation. An idealized section of a rhyolitic lava flow mapped by F. M. Byers, Jr., and others of the U.S. Geological Survey (written commun., 1964) contains an upper and lower envelope of rubble breccia, upper and lower glass zones, and a crystalline zone in the middle. Contacts between the zones are gradational, and each of the five zones is approximately equal in thickness. Porosities calculated from surface samples of the rubble breccia range from 28.9 to 70.2 percent; porosities of the crystalline and glassy zones range from 1.2 to 12.3 percent. The porosities of the brecciated zones of flows in the subsurface are likely to be lower owing to compaction and to filling of pores with mineral matter.

A rhyolitic lava flow with foliated interior and enveloped by breccia was mapped near Fortymile Canyon, south of Pahute Mesa, by Christiansen and Lipman (1966). Erosion in the area of the flow exposed the vent for the lava flow and the preeruption topography, and thus provided evidence "that brecciation of the lava flow occurred mainly during periods when the lava was spreading, whereas the body eroded its floor and walls much as does a glacier during periods when the flow was confined" (Christiansen and Lipman, 1966, p. 671). The authors noted that tuff adjacent to parts of the lava flow was compacted and indurated. This zone of induration or fusion affected the tuff locally for a thickness of 245 feet from the contact of the flow.

Cooling of lava and indurated tuff at a contact zone results in shrinkage cracks and, hence, an interconnected fracture system. Radioactive-tracer surveys during pumping of some drill holes indicated major water-yielding zones at or near contacts between lava flows and tuff. 
CHARACTERISTICS BASED ON CORES, GEOPHYSICAL LOGS, AND DRILLING RECORDS

Cores in exploratory drill holes generally were taken where a change in rock type was indicated by a change in the rate of penetration (drilling time) or was detected from examination of rock cuttings recovered from the hole. None of the drill holes was cored continuously, and few intervals of similar rocks, such as lava flows, were cored continuously. Less than 5 percent of the total section penetrated was cored.

General descriptions based on cores and rock cuttings of rhyolitic lava flows assigned to the lava and tuff of Deadhorse Flat and the tuffs and rhyolites of Area 20, are satisfactory for gross stratigraphic correlations. However, the lack of continuous cores through lava flows does not permit a statistical analysis of fracture systems or vertical structural zonation within isolated flows or series of flows. In addition, the percentage of core recovered from highly fractured intervals generally is low.

The number of measurable fractures per foot of core, based on descriptions of 127 cored intervals from 12 drill holes, ranged from 0 to 4.3 . The fractures, most of which resulted from shrinkage during cooling of the flows, show little or no vertical displacement and may be classed as joints. Vertical and high-angle (greater than $60^{\circ}$ ) joints are more common than low-angle and horizontal joints. The joints are tight or slightly open in cores and often part when the core is removed from the core barrel.

Slight vertical displacements noted along some fractures are related to flow structure or reflect nearby faulting. Much faulting has occurred at Pahute Mesa, and the number of faults mapped on the surface ranges from 0 to 10 per square mile. These faults and associated fractures generally remain open in the competent lava flows and contribute to the overall permeability, especially the vertical permeability. Faults in the lava flows are difficult to detect from rock cuttings recovered from the drill hole. Probably, some of the most permeable intervals measured in drill holes are associated with faults rather than with the fractures related to flow structure.

Most of the cores of rhyolitic lava flows recovered from drill holes contain some fractures; however, not all the intervals that are fractured are permeable. In intervals of low permeability, fractures apparently are not interconnected or are poorly connected. In the UE-19b-1 exploratory hole, rhyolitic lava flows are the principal rocks in the upper 2,000 feet of the saturated zone; the upper 1,000 feet has highly permeable intervals, but the lower 1,000 feet is relatively impermeable. Data from a radioactive-tracer survey made in the UE-19b-1 hole, which was being pumped at a constant rate of $88 \mathrm{gpm}$, indicated that only 4 percent of the section penetrated in the saturated zone yielded water to the borehole.

Most of the fractures in the rhyolitic lava flows are coated with manganese oxide, however, at depth, some are filled with quartz. The depths below the top of the saturated zone at which fractures remain open and interconnected are variable. Highly permeable rhyolitic lavas occur at depths greater than 3,000 feet below the saturated zone in the UE-20f exploratory hole. In general, the intervals having the highest permeability occur in the uppermost 2,000 feet of the saturated zone.

Cores recovered from various intervals within a rhyolitic lava flow may include vitrophyre and rubble breccia. The vitrophyres generally are highly fractured and permeable; permeability of the breccias is variable.

Flowbanding is common in many rhyolite cores; layers range from less than $5 \mathrm{~mm}$ (millimeters) to more than $100 \mathrm{~mm}$; dips range from horizontal to vertical. Some interstitial permeability may result from vapor-phase cavities that are alined with the flowbanding. D. L. Hoover and others (written commun., 1964) found such vapor-phase cavities from 3 by $100 \mathrm{~mm}$ to 10 by $50 \mathrm{~mm}$ in the lava flow penetrated in the U-20a-2 exploratory hole at a depth of 2,893 to 2,901 feet - within one zone of high permeability (table 7 ). Interstitial permeability in the lava flows, however, is not considered significant in ground-water movement under Pahute Mesa.

The obtention of meaningful effective porosity data from samples of fractured rhyolitic lava flows is extremely difficult. Calculations of total porosity, using grain densities and bulk densities of cores, have been made by various geologists of the U.S. Geological Survey. Calculated porosities of rhyolitic lavas of the tuffs and rhyolites of Area 20 range from 1.7 to 44.4 percent; the average porosity, based on 48 samples, is 15.5 percent. Calculated porosities of rhyolitic lavas of the lava and tuff of Deadhorse Flat are lower. Porosities in these rocks range from 1.2 to 26.2 percent, and the average porosity, based on 79 samples, is 11.1 percent.

R. D. Carroll determined total porosities of rocks from geophysical logs made in drill holes. When grain density of rock samples taken from the hole were relatively uniform, Carroll determined porosities from density logs. Other logs used for determination of porosity were neutron, electric, and 
sonic logs. Total porosities of rhyolitic lava flows of the lava and tuff of Deadhorse Flat from density logs made in the UE-19d exploratory hole ranged from 3 to 15 percent - that of most of the rhyolitic lava section was about 12 percent. Total porosities of an equivalent section of lava flows derived from neutron logs made in the UE-19b-1 exploratory hole ranged from 2 to 16 percent. Porosities of rhyolitic lava flows of the tuffs and rhyolites of Area 20, from laboratory calculations and from geophysical log determinations, generally were greater than those of the lava and tuff of Deadhorse Flat. Porosities of rhyolitic lava flows of the tuffs and rhyolites of Area 20 determined from geophysical logs made in the UE-20f exploratory hole ranged from 3 to 31 percent. No relation between porosity and type and degree of alteration of rhyolitic lava flows - zeolitization, argillization, or devitrification - was established. Generally no significant changes in porosity were noted in parts of flows that were altered.

The normal and lateral resistivity curves on electric logs made in exploratory holes at Pahute Mesa are excellent indicators of rock types. Borehole fluid resistivities are such that the apparent resistivity of the 16-inch normal curve can be taken as the true resistivity of the formation at apparent resistivities less than $1,000 \mathrm{ohms}-\mathrm{m}^{2} / \mathrm{m}$. Resistivities of relatively impermeable zeolitized tuff units are usually less than $100 \mathrm{ohms}-\mathrm{m}^{2} / \mathrm{m}$ on the short normal curve of the log; apparent resistivities of densely welded tuff, vitrophyre, and rhyolitic lavas exceed $225 \mathrm{ohms}-\mathrm{m}^{2} / \mathrm{m}$. Percentages of resistivity ranges in the saturated zone in drill holes, based on interpreta- tion of electric logs, are shown in table 2. Alteration of rhyolitic lava flows may increase ion concentration and result in low apparent resistivities (R. D. Carroll, written commun., 1965). Hence, contacts between rock types are most precise when they are based on interpretation and correlation of electric, sonic, density, and caliper logs.

The caliper log often indicates rock type and fractured intervals and thus yields information related to porosity and permeability. The caliper curve is usually smooth, and the diameter of the borehole is in gauge with the drill-bit size through sections of competent, nonfractured welded tuff and rhyolites; borehole rugosity and angular caved zones are indicated on the $\log$ in highly fractured intervals. Prominent ledges and abrupt "washed-out" zones often occur at the contacts between rhyolitic lava flows and the less competent zeolitized tuffs.

Fractured intervals can be detected on velocity $\operatorname{logs}$; fractures may attenuate the sonic signal and can be recorded on the sonic log by "cycle skipping" (R. D. Carroll, written commun., 1965). Borehole rugosity and angular caved zones, indicative of fracturing, also may cause cycle skipping on the sonic $\log$. The three-dimensional velocity $\log$, used in conjunction with other logs, also is useful for identifying fractured intervals.

Drilling time (the time required to drill a unit of depth of a geologic formation) is an excellent indicator of rock type and especially of the contacts between rock types. In exploratory holes, drilling times for 10-foot units of rhyolitic lava flows and densely welded tuff range from 10 to more than 260 minutes and average 70 minutes; drilling times for

TABLE 2. - Resistivity calculations from 16-inch normal curve on electric logs made in upper 2,000 feet of zone of saturation in exploratory holes, Pahute Mesa

\begin{tabular}{|c|c|c|c|c|c|c|}
\hline \multirow[t]{2}{*}{$\begin{array}{c}\text { Exploratory } \\
\text { hole }\end{array}$} & \multirow[t]{2}{*}{$\begin{array}{c}\text { Depth to } \\
\text { water below } \\
\text { land surface } \\
(\mathrm{ft})\end{array}$} & \multirow{2}{*}{$\begin{array}{c}\text { Total depth of } \\
\text { hole below } \\
\text { land surface } \\
\text { (ft) }\end{array}$} & \multirow[t]{2}{*}{$\begin{array}{c}\text { Depth below } \\
\text { land surface } \\
\text { of interval used } \\
\text { for calculations } \\
\text { (ft) }\end{array}$} & \multicolumn{3}{|c|}{$\begin{array}{c}\text { Percentage of interval } \\
\text { having resistivity in } \\
\text { the indicated range } \\
\left(\text { ohms }-\mathrm{m}^{2} / \mathrm{m}\right)\end{array}$} \\
\hline & & & & $0-100$ & $100-225$ & $>225$ \\
\hline $\mathrm{UE}-19 \mathrm{~b}-1$. & 2,117 & 4,500 & $2,200-4,200$ & & & 100 \\
\hline $\mathrm{UE}-19 \mathrm{c}$ & 2,345 & 8,489 & $2,340-4,340$ & $<1$ & $>1$ & 98 \\
\hline UE-19d.... & 2,177 & 7,689 & $2,177-4,177$ & & $<1$ & 99 \\
\hline UE-19e.. & 2,240 & 6,005 & $2,200-4,200$ & 76 & 16 & 8 \\
\hline UE-19fs.. & 2,305 & 6,950 & $22,300-4,300$ & 24 & 11 & 65 \\
\hline UE-19gs... & 2,045 & 7,500 & $2,350-4,100$ & 25 & 33 & 42 \\
\hline $\mathrm{UE}-19 \mathrm{~h}$. & 2,112 & 3,705 & $2,100-3,700$ & 18 & 10 & 72 \\
\hline UE-19i...... & 2,258 & 8,000 & $2,260-4,260$ & 62 & 25 & $1 \overline{3}$ \\
\hline $\mathrm{PM}-1 \ldots .$. & 2,112 & 7,858 & $2,110-4,110$ & 92 & 8 & $\ldots$. \\
\hline PM-2.. & 865 & 8,781 & $1,050-3,050$ & $9 \overline{3}$ & 4 & 3 \\
\hline $\mathrm{U}-20 \mathrm{a}-2$ & 2,066 & 4,500 & $2,100-4,100$ & & 7 & 93 \\
\hline UE-20d... & 2,075 & 5,348 & $2,075-4,075$ & 73 & 5 & 22 \\
\hline $\mathrm{UE}-20 \mathrm{e}-1$ & 1,822 & 6,395 & $1,820-3,820$ & 64 & 14 & 22 \\
\hline UE-20f........ & ${ }^{4} 1,954$ & 13,686 & $1,960-3,960$ & 72 & 7 & 21 \\
\hline U-20g (Satellite No. 1). & 2,017 & 4,080 & $2,400-4,015$ & 66 & 30 & 4 \\
\hline UE-20h & 2,116 & 7,207 & $2,105-4,105$ & 44 & 8 & 48 \\
\hline $\mathrm{UE}-20 \mathrm{j} \ldots \ldots$ & 1,270 & 5,690 & $1,270-3,270$ & 78 & 15 & 7 \\
\hline
\end{tabular}

Depths of interval used for calculations may be limited by actual depths logged.

'Zone between 2,300 and 2,500 based on geology because no logs were available.

${ }^{3}$ Zone between 3,454 and 3,700 based on geology because no logs were available.

4 Water level after hole had been drilled to $4,543 \mathrm{ft}$ below land surface. 
10-foot units of ash-fall tuff and nonwelded to partially welded ash-flow tuff rarely exceed 80 minutes and average 20 minutes.

A positive indication of highly fractured, permeable zones in rhyolitic lava flows during drilling is the complete or partial loss of drilling fluid and rock cuttings. Circulation is lost when fractures are sufficiently open to accept both drilling fluid and rock cuttings without becoming plugged. Loss of circulation, particularly if accompanied by a sharp increase in deviation of the drill hole, may be indicative of a major fault. Major fractures in rhyolite also may deflect the drill bit, but generally the bit will dig into the updip side rather than drift along the plane of the fracture.

Ledges in the drill hole often occur at the contact between ash-flow or ash-fall tuffs and rhyolitic lavas. These ledges create ideal circumstances for development of bridges - the result of caving of the walls of the borehole and accumulation of material - and thus prevent passage of drill pipe and testing tools.

\section{CHARACTERISTICS BASED ON HYDRAULIC TESTS}

Hydraulic testing in each exploratory drill hole involves geophysical logging, injection of known volumes of water into or withdrawing known volumes of water from intervals isolated by straddle packers, and test pumping. Equipment and testing techniques used by the U.S. Geological Survey to obtain hydrologic data in deep holes drilled at Pahute Mesa have been described by Blankennagel (1967 and 1968).

The length of intervals isolated by straddle packers is determined by hole diameter, hole condition, and lithology and generally ranges from 150 to 200 feet. Data on head changes and relative specific capacities (gallons per minute per foot of drawdown) of isolated intervals are obtained by injecting or withdrawing known volumes of water and measuring the rate of change of water levels with time.

Relative specific capacity is the yield, in gallons per minute, accepted or released by a given length of bore (usually $200 \mathrm{ft}$ ) in response to a 1-foot-ofwater pressure differential. The rate at which the straddle-packed interval accepts water during a slug injection test, or yields water after swabbing, is calculated for the period 3-4 minutes after injection of water or cessation of swabbing. The choice of 3-4 minutes is an arbitrary one, but similar or identical yield rates are derived at later times. Moreover, similar or identical rates are derived if the rate is calculated at points of equal head rather than equal time.
The term "relative specific capacity" is employed rather than the more familiar term "specific capacity" because of the following consideration. A comparison of the specific capacity values derived from drill-stem tests of permeable intervals with those from pumping tests of the same intervals has shown that the injection or swabbing-test data for permeable zones may be low by a factor of as much as 50 . For low yielding zones, on the other hand - that is, those with relative specific capacity less than 0.05 gpm per foot - injection and swabbing-test data yield information which is comparable to that which could be obtained if these holes were pumped. Therefore, because the values for the permeable intervals are not absolute values, in comparison with those obtained for the relatively impermeable zones, the term "relative specific capacity" is utilized in this report.

Most of the water pumped from exploratory drill holes is obtained from zones of fracture permeability that constitute only 3 to 10 percent of the total section penetrated in the saturated zone. Where high relative specific capacities are measured in the 150- to 200-foot intervals of rhyolitic lavas isolated by straddle packers, one or more thin zones of interconnecting fractures that range from less than 10 feet to several tens of feet in thickness generally account for most of the permeability in the interval. Delineation of these highly permeable intervals in drill holes is done by means of radioactive-tracer surveys while pumping or injecting water at a constant rate, and by examination of electric, fluid resistivity, caliper, and temperature logs.

Submersible pumps were used during testing of exploratory holes when drilling records indicated that pumping rates of 50 or more gallons per minute could be sustained. The principal justification for pumping exploratory drill holes was to delineate permeable zones and to obtain data on the water yielded by each zone. These data were obtained from detailed radioactive-tracer surveys and temperature logs made in the hole while pumping at a constant rate. Most of the holes in which these surveys were made were pumped for periods of 12 or 24 hours to stabilize production prior to the geophysical logging; during these periods water-level drawdown was measured. These pumping-test data often proved inadequate because of the heterogeneous aquifer systems, time limitations, and erratic measurements caused by foaming of detergents used during drilling. Nevertheless, the data were useful for determining approximate transmissivities, specific capacities, and the potential water yield of wells. No observation wells were available; hence, all calculations were. based on single-well tests. 
Pumping tests were made in 14 exploratory holes at Pahute Mesa. In 12 of these holes, the major water production was obtained from fractured zones in rhyolitic lava flows; production was obtained from fractured welded tuff in the UE-19e and UE-20j drill holes. Transmissivities from pumping tests generally ranged from 1,400 to $140,000 \mathrm{gpd}$ per ft (gallons per day per foot); specific capacities ranged from 0.7 to $67 \mathrm{gpm}$ per foot of drawdown (table 3 ). The highest transmissivities were measured in those holes where rhyolitic lava flows were the major rock types penetrated in the upper 2,000 feet of the zone of saturation.

In drill holes UE-19h and U-20a-2, where rhyo- litic lava flows are the predominant rock, transmissivities are relatively high, and drawdown graphs during the time of measurements (figs. 5 and 6) indicate that the water-bearing fractures probably are well connected. In drill holes where rhyolitic lavas are the major water-producing rocks, but where ash-fall and ash-flow tuffs are the principal rocks penetrated in the upper 2,000 feet of the saturated zone, transmissivities are generally lower and permeability barriers may be interpreted from drawdown plots at lower pumping rates and in less time. In the UE-20e-1 drill hole, rhyolitic lava flows comprise less than 25 percent of the rock type penetrated in the saturated zone; an abrupt

TABLE 3. - Results from pumping tests of exploratory holes, Pahute Mesa

$[<$, less than ; $>$, greater than $]$

\begin{tabular}{|c|c|c|c|c|c|c|c|c|c|}
\hline \multirow[b]{2}{*}{$\begin{array}{c}\text { Exploratory } \\
\text { hole }\end{array}$} & \multirow{2}{*}{$\begin{array}{l}\text { Depth of } \\
\text { hole below } \\
\text { land } \\
\text { surface } \\
\text { (ft) }\end{array}$} & \multirow[b]{2}{*}{$\begin{array}{l}\text { Depth of } \\
\text { casing } \\
(\mathrm{ft})\end{array}$} & \multirow{2}{*}{$\begin{array}{c}\text { Depth to } \\
\text { water below } \\
\text { land } \\
\text { surface } \\
\text { (ft) }\end{array}$} & \multicolumn{5}{|c|}{ Pumping-test data } & \multirow[b]{2}{*}{ Remarks } \\
\hline & & & & $\begin{array}{c}\text { Yield } \\
(\mathrm{gpm})\end{array}$ & $\begin{array}{l}\text { Draw- } \\
\text { down } \\
(\mathrm{ft})\end{array}$ & $\begin{array}{c}\text { Specific } \\
\text { capacity } \\
\text { (gpm } \\
\text { per } \mathrm{ft} \text { ) }\end{array}$ & $\begin{array}{l}\text { Transmis- } \\
\text { sivity } \\
\text { (gpd } \\
\text { per } f t \text { ) }\end{array}$ & $\begin{array}{c}\text { Duration } \\
\text { of } \\
\text { test } \\
\text { (hours) }\end{array}$ & \\
\hline$\overline{\mathrm{UE}}-18 \mathrm{r}^{1} \ldots \ldots \ldots \ldots$ & 5,004 & 1,629 & 1,372 & 240 & 19 & 13 & 23,000 & 47 & $\begin{array}{l}\text { Test interrupted by } \\
\text { pump and gen- } \\
\text { erator failures. }\end{array}$ \\
\hline TW-8' & 5,490 & 2,936 & 1,068 & 400 & $<8$ & $>50$ & 185,000 & 35 & \\
\hline 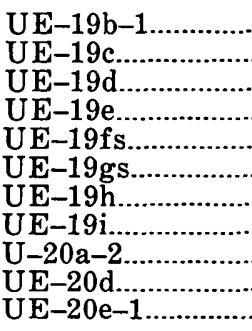 & $\begin{array}{l}4,500 \\
4,520 \\
7,689 \\
6,005 \\
4,779 \\
4,508 \\
3,705 \\
8,000 \\
4,500 \\
4,493 \\
6,395\end{array}$ & $\begin{array}{r}2,190 \\
2,421 \\
2,560 \\
2,475 \\
2,565 \\
2,650 \\
2,322 \\
2,896 \\
8600 \\
2,446 \\
1,500\end{array}$ & $\begin{array}{l}2,117 \\
2,345 \\
2,177 \\
2,240 \\
2,305 \\
2,045 \\
2,112 \\
2,258 \\
2,066 \\
2,075 \\
1,822\end{array}$ & $\begin{array}{r}97 \\
59 \\
100 \\
56 \\
130 \\
185 \\
185 \\
140 \\
186 \\
60 \\
94\end{array}$ & $\begin{array}{r}<2 \\
10 \\
10 \\
53 \\
32 \\
37 \\
<3 \\
200 \\
23 \\
<2 \\
13\end{array}$ & $\begin{array}{r}>50 \\
6 \\
10 \\
1 \\
4 \\
5 \\
67 \\
\quad .7 \\
8 \\
>40 \\
7\end{array}$ & $\begin{array}{c}56,000 \\
12,000(?) \\
20,000(?) \\
8,400 \\
11,000 \\
30,000 \\
140,000 \\
1,400 \\
18,000 \\
>44,000(?) \\
8,300\end{array}$ & $\begin{array}{l}12 \\
33 \\
22 \\
24 \\
24 \\
24 \\
28 \\
17 \\
29 \\
25 \\
28\end{array}$ & Impervious bound- \\
\hline UE-20f.. & 13,686 & 4,456 & 1,954 & 100 & 210 & .5 & $>1,000(?)$ & 47 & $\begin{array}{l}\text { Most permeable } \\
\text { zone cased off. }\end{array}$ \\
\hline $\mathrm{UE}-20 \mathrm{~h}$ & 7,207 & 2,506 & 2,116 & 85 & 5 & $\begin{array}{r}17 \\
8\end{array}$ & 11000 & 38 & \\
\hline UE-20j..................... & 5,690 & 1,740 & 1,270 & 56 & $>3$ & 16 & 59,000 & 23 & $\begin{array}{l}\text { Impervious bound- } \\
\text { ary nearby. }\end{array}$ \\
\hline
\end{tabular}

${ }^{1}$ South of Pahute Mesa.

steepening of the drawdown graph (fig. 7) after 40 minutes of pumping is indicative of a probable reduction in fracture permeability away from the borehole. The steepening of the drawdown graph (fig. 5) for hole UE-19h drawdown test did not occur until after 650 minutes at nearly twice the pumping rate.

Lowest transmissivities and specific capacities were recorded in holes UE-19e and UE-19i, where rhyolitic lava flows made up only 5 percent of the rocks in the saturated zone, and in hole UE-20f, where the upper 2,500 feet of the saturated zone was cased and cemented. In hole UE-20f, the interval from 4,456 to 13,686 feet was pumped; this test indicated that open, water-bearing fractures occur at depths greater than 2,500 feet below the top of the saturated zone, or about 4,500 feet below land surface.

\section{WELDED TUFFS}

Data on hydraulic properties of welded tuffs at Pahute Mesa are not as numerous as those collected for other rocks. The combined percentage of ash-fall and nonwelded ash-flow tuffs and rhyolitic lava flows penetrated in the upper 2,000 feet of the saturated zone in 17 exploratory holes is more than seven times greater than the percentage of welded tuffs. Densely welded tuffs have physical characteristics like those of rhyolitic lava flows. Like the rhyolitic lava flows, they have a wide range in water-yield potential; interconnecting fractures afford the principal avenues for ground-water movement. 


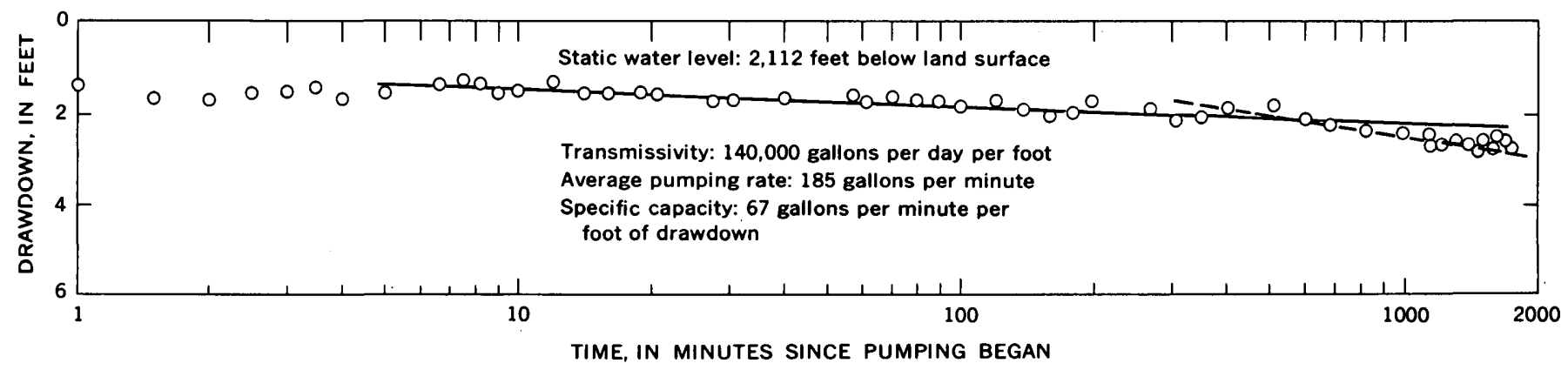

FigURE 5. - Drawdown during 28-hour pumping test of hole UE-19h, August 4-5, 1965.

The principal members of the Belted Range Tuff - the Grouse Canyon and Tub Spring - are relatively impermeable except in those areas that have been disturbed by faulting. Welded tuffs of the intracaldera rocks do not have the areal extent and uniformity of the widespread ash-flow sheets of the Belted Range and the postcaldera ash flows. With some exceptions, most of the welded tuffs assigned to the intracaldera rocks are relatively impermeable. Welded tuffs of the Paintbrush Tuff, specifically the Tiva Canyon and Topopah Spring Members, are relatively permeable but occur within the saturated zone only in the southwestern part of the caldera.

\section{CHARACTERISTICS OF SURFACE EXPOSURES}

The widespread postcaldera ash-flow sheets that formed Pahute Mesa are well exposed in deep canyons and ravines and along the face of the mesa; excellent exposures also are found in surrounding areas within and outside the Nevada Test Site.
Hence, most of these ash-flows have been mapped in considerable detail, and descriptions are given in publications such as those by Carr (1964), Noble and others (1964), Orkild (1965), and Lipman and others (1966). One of the most comprehensive discussions on ash flows (deposits of ash resulting from flowage of a highly heated mixture of volcanic ash and unsorted material containing gas) is that by Ross and Smith (1961). They noted that columnar joints are common in welded tuffs, and joints are more closely spaced in the zones of most intense welding; similar jointing does not usually occur in the nonwelded parts of flows. Horizontal platy jointing commonly occurs in or near the zone of maximum compaction.

Because of the uniformity of the widespread postcaldera ash-flow sheets and the common occurrence of columnar jointing in the welded zones, these rocks generally are good aquifers. Welded tuffs, however, have lower compressive strength than

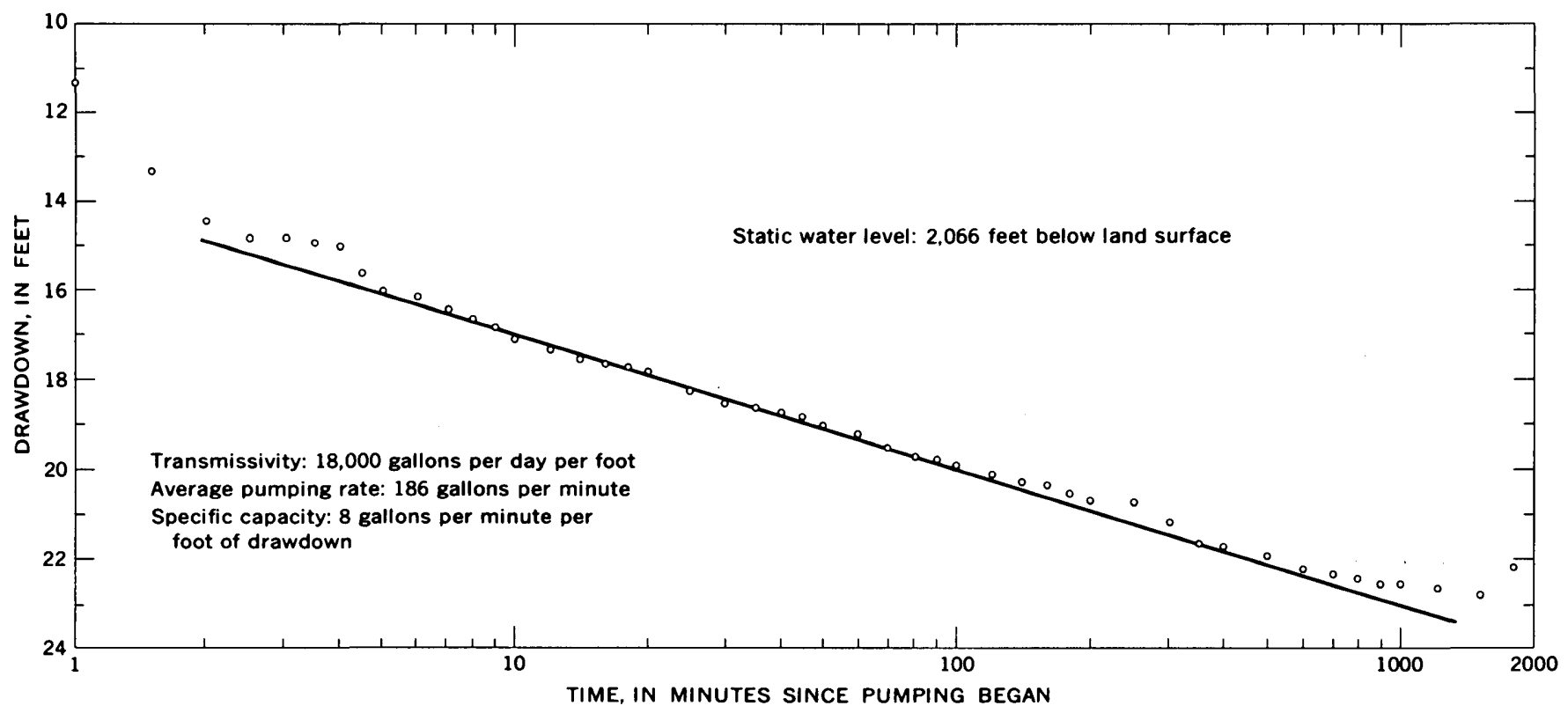

Figure 6. - Drawdown during 29-hour pumping test of hole U-20a-2, February 10-12, 1965. 
rhyolitic lavas, and fractures commonly are resealed or healed where they occur at depths greater than 1,000 feet below the top of the saturated zone. For these reasons the welded tuffs of the Belted Range Tuff and most of the welded tuffs in the lava and tuff of Deadhorse Flat and the tuffs and rhyolites of Area 20 are poor aquifers.

Ash-flow tuffs range from nonwelded and poorly consolidated to densely welded. Interstitial porosity of the nonwelded tuff may exceed 50 percent (Ross and Smith, 1961), and interstitial permeability of these rocks may exceed $2 \mathrm{gpd}$ per square foot. Interstitial porosity and permeability decrease with an increase in the intensity of welding. Pore space generally is not entirely eliminated in the thoroughly from 4.2 to 38.4 percent (table 4 ) ; the more intensely welded samples ranged from 4.2 to 13 percent. Samples usually are described as partly welded, moderately welded, or densely welded. Because of the direct relationship between porosity and the degree of welding, Ratté and Steven (1967) suggested that a numerical value of porosity would more effectively express the degree of welding than the undefined terms listed above. They would classify rocks having less than 10 percent porosity as densely welded and those having more than 10 percent as partly welded.

Most welded tuffs are devitrified, a postdepositional alteration that changes both the matrix and the pumice fragments into crystalline material.

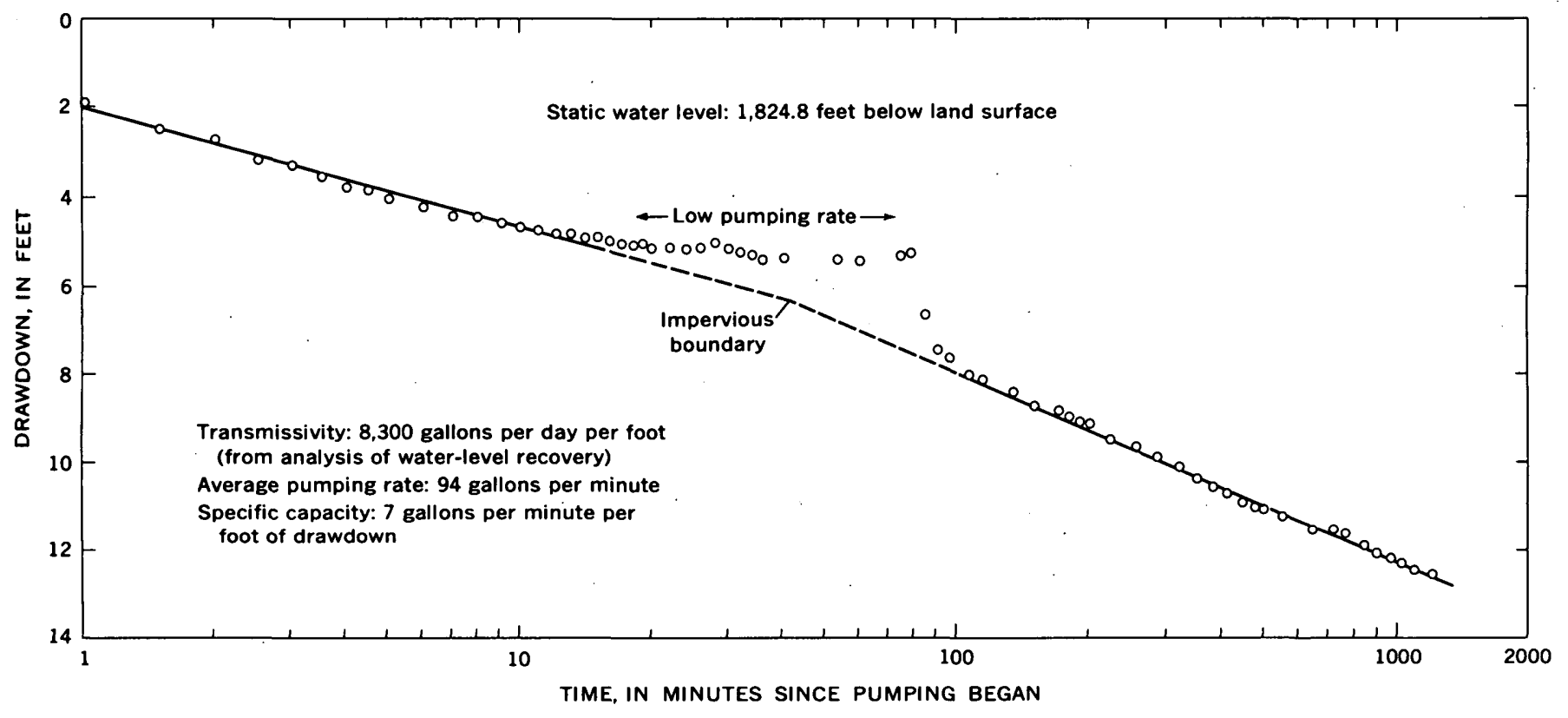

Figure 7. - Drawdown during a pumping test of hole UE-20e-1, June 4-5, 1964.

welded zones, but porosity may be only a few percent, and interstitial permeability may be less than $2 \times 10^{-5} \mathrm{gpd}$ per square foot (Winograd and others, 1971). Interstitial porosity and permeability of the nonwelded and partially welded tuffs may be large enough to be significant in regional ground-water movement; however, interstitial porosity and permeability of the densely welded tuffs are too low to contribute significantly to ground-water movement. Ground water moves through densely welded tuffs principally along primary and secondary joints and other fractures associated with faults.

CHARACTERISTICS BASED ON CORES, GEOPHYSICAL LOGS, AND DRILLING RECORDS

Total porosity from core samples of welded tuffs in the saturated zone under Pahute Mesa ranged
However, porosity ranges of vitric and devitrified welded tuff are similar. Lithophysal cavities and gas pockets occur in some welded tuffs and, locally, may contribute to interstitial porosity and permeability.

All core samples recovered from the welded zones of the postcaldera ash-flow sheets contained fractures; the number of fractures ranged from 0.5 to 2.5 per foot of core and averaged 1.4 per foot. Many core samples of welded tuffs from the intracaldera rocks contained no open fractures, but fractures that were sealed with quartz and other minerals were common.

A measure of the degree of welding of tuff can be determined from resistivity curves of electric logs. Most resistivities of moderately welded tuffs are between 100 and $225 \mathrm{ohms}-\mathrm{m}^{2} / \mathrm{m}$; but densely welded 
TABLE 4. - Summary of porosity and fracture frequency in core samples of welded tuffs

[Compiled from unpublished data prepared by U.S. Geological Survey]

\begin{tabular}{|c|c|c|c|c|c|c|}
\hline Formation & $\begin{array}{c}\text { Exploratory } \\
\text { hole and, in } \\
\text { parentheses, } \\
\text { number of cores }\end{array}$ & $\begin{array}{c}\text { Number } \\
\text { of } \\
\text { cores }\end{array}$ & $\begin{array}{c}\text { Range in } \\
\text { total } \\
\text { porosity } \\
\text { (percent) }\end{array}$ & $\begin{array}{l}\text { Average } \\
\text { total } \\
\text { porosity } \\
\text { (percent) }\end{array}$ & $\begin{array}{l}\text { Range in } \\
\text { number of } \\
\text { fractures } \\
\text { per } \mathrm{ft}\end{array}$ & $\begin{array}{c}\text { Average } \\
\text { number of } \\
\text { fractures } \\
\text { per ft }\end{array}$ \\
\hline $\begin{array}{l}\text { Tiva Canyon } \\
\text { Member of } \\
\text { Paintbrush Tuff. }\end{array}$ & $\begin{array}{l}\text { UE-20d (1), } \\
\text { UE-20f (1), } \\
\text { UE-20c (2) }\end{array}$ & 4 & $7.2-17.2$ & 14 & $0.5-2.2$ & 1.4 \\
\hline $\begin{array}{l}\text { Topopah Spring } \\
\text { Member of } \\
\text { Paintbrush Tuff. }\end{array}$ & $\begin{array}{l}\text { UE-20d (1), } \\
\text { UE-20f (1), } \\
\text { UE-20c (7) }\end{array}$ & 9 & $12.8-36.2$ & 22 & $.7-2.5$ & 1.4 \\
\hline $\begin{array}{l}\text { Tuffs and rhyolites } \\
\text { of Area } 20 \text {. }\end{array}$ & $\begin{array}{l}\mathrm{UE}-19 \mathrm{i}(1) \\
\mathrm{UE}-20 \mathrm{e}-1(1), \\
\text { UE-20h }(2)\end{array}$ & 4 & $13.7-31.1$ & 22.9 & $0-.1$ & $<.1$ \\
\hline $\begin{array}{l}\text { Lava and tuff of } \\
\text { Deadhorse Flat. }\end{array}$ & $\begin{array}{l}\text { UE-19b-1 (4), } \\
\text { UE-19e (5), } \\
\text { UE-19gs (4), } \\
\text { UE-19i (1) }\end{array}$ & 14 & $12.9-33.5$ & 21.4 & $0->4$ & $>.7$ \\
\hline $\begin{array}{l}\text { Grouse Canyon } \\
\text { Member of } \\
\text { Belted Range Tuff. }\end{array}$ & $\begin{array}{l}\text { UE-19e (1), } \\
\text { UE-19gs (10), } \\
\text { UE-19i (1), } \\
\text { UE-20e-1 (1), } \\
\text { UE-20j (1) }\end{array}$ & 14 & $4.2-24.0$ & 12.1 & $0-3.2$ & .9 \\
\hline $\begin{array}{l}\text { Tub Spring } \\
\text { Member of } \\
\text { Belted Range Tuff. }\end{array}$ & $\begin{array}{l}\text { UE-19fs (1), } \\
\text { UE-19h (2), } \\
\text { UE-20j (1), } \\
\text { PM-2 (1) }\end{array}$ & 5 & $8.1-38.4$ & 19.6 & $0-7.5$ & 1.8 \\
\hline
\end{tabular}

tuffs and tuff vitrophyres have physical properties like those of rhyolitic lavas, and, their resistivities are in the same range as those of rhyolitic lavas. In general, geophysical logs indicate that the parameters for identification of rhyolitic lavas in the subsurface also apply to the densely welded zones of tuffs, and very often the rocks cannot be distinguished from one another. However, the fact that the densely welded zones usually grade vertically into less-welded zones and nonwelded zones facilitates their identification on the basis of geophysical logs.

Drilling rates in most welded tuffs range between the rates for ash-fall and nonwelded tuffs and the rates for competent rhyolitic lava flows. Drilling characteristics and the parameters for detection of highly fractured, permeable zones in densely welded tuffs and rhyolitic lava flows are similar.

CHARACTERISTICS BASED ON HYDRAULIC TESTS

Welded tuff was the principal rock in at least 41 intervals that were isolated by straddle packers in drill holes and tested by adding or withdrawing water. Relative specific capacities of 26 of the intervals tested (63 percent of the total) ranged from less than 0.01 to $0.02 \mathrm{gpm}$ per foot of drawdown. Relative specific capacities of 0.1 to $0.5 \mathrm{gpm}$ per foot of drawdown were measured in seven of the intervals tested, and of this total, five were for rocks of the Grouse Canyon Member in the UE-20j drill hole, and one was for the rocks of the Tub Spring
Member in the UE-19h drill hole. The UE-20j hole was drilled near the ring-fracture zone of the caldera, and there was much evidence of faulting in core samples recovered. Data are illustrated in figure 4.

The only consistently permeable welded tuffs are those assigned to the Tiva Canyon and Topopah Spring Members. These units occur within the saturated zone in the southwestern part of the caldera, and, where tested, relative specific capacities ranged from 0.04 to $0.15 \mathrm{gpm}$ per foot of drawdown. The welded tuffs in these widespread ash-flow sheets are aquifers in other parts of the Nevada Test Site, such as Jackass Flats in the southwestern part, where the Topopah Spring Member is the principal aquifer penetrated in production wells (R. A. Young, 1972).

Welded tuff was the principal aquifer in only one of the holes test pumped (UE-20j) where production was from highly fractured welded tuffs and zeolitized bedded tuffs.

\section{ASH-FALL TUFFS, NONWELDED OR SLIGHTLY WELDED} ASH-FLOW TUFFS, AND TUFFACEOUS SEDIMENTS

Although their origin and mode of emplacement differs, ash-fall and nonwelded or slightly welded ash-flow tuffs have similar physical properties and hydraulic characteristics. Interstitial porosity and permeability of these rocks, and of the reworked tuffs, are greater than those of the rhyolitic lavas and densely welded tuff. However, fractures resealed more readily in these relatively incompetent rocks; 
hence, fracture porosity and permeability generally are much lower than those of the rhyolitic lavas and densely welded tuffs. Yield of water to wells from ash-fall and nonwelded ash-flow tuffs is low, and for this reason these rocks are considered the best media for mining of chambers within the saturated zone.

In the western part of the caldera, tuffs are the predominant rocks in the saturated zone. The thicknesses of zeolitized bedded tuffs which are interlayered with rhyolitic lava flows in the tuffs and rhyolites of Area 20 range from 10 feet to more than 850 feet; an exceptional thickness of 1,750 feet was penetrated in the PM-1 drill hole. Zeolitized nonwelded ash-flow tuffs attain thicknesses greater than 600 feet, and in the PM-1 drill hole lithic-rich nonwelded ash-flows have a thickness of more than 2,000 feet.

In the eastern part of the caldera, rhyolitic lava flows are the predominant rocks in the saturated zone; thicknesses of ash-fall and ash-flow tuffs between these lava flows are not as great as in the western part of the caldera. The thickness of zeolitized bedded tuff ranges from 25 feet to 170 feet; zeolitized nonwelded ash-flow tuffs range in thickness from 20 feet to 280 feet.

Intervals that have undergone argillization generally are thinner; the average thickness of these intervals is 10 feet. However, a few intervals with thicknesses in excess of 200 feet are known.

CHARACTERISTICS OF SURFACE EXPOSURES

Most ash-fall and nonwelded ash-flow tuffs that are exposed at the surface in the report area do not occur in the saturated zone. East of the caldera, however, ash-fall and ash-flow tuffs assigned to the Belted Range Tuff crop out. These rocks, where penetrated within the caldera, are at great depths and are highly impermeable.

Surface exposures of incompetent ash-fall and ash-flow tuffs generally are poor; the rocks are best observed in roadcuts and in gullies along the flanks of mesas. The topographic expression of the outcrops is that of gentle rounded hills, but cliffs may form where there is considerable case hardening. Wind erosion causes a pock-marked or honeycombed effect in some areas.

Ash-fall tuffs are varicolored, fine grained with lapilli of various diameters, generally well sorted, thin to thick bedded, vitric and devitrified, zeolitic, and friable to well cemented. The nonwelded ashflows are varicolored, massive, poorly sorted, vitric and devitrified, and locally zeolitized. Reworked tuffs are fine to coarse grained, well sorted to poorly sorted, thin bedded to massive, and often cross- bedded. Fractures and minor fault displacements are common, but many are resealed.

\section{CHARACTERISTICS BASED ON CORES, GEOPHYSICAL LOGS, AND DRILLING RECORDS}

In the saturated zone, the formations containing the greatest thicknesses of ash-fall and nonwelded ash-flow tuffs and of reworked tuffs and volcanic sediments are the tuffs and rhyolites of Area 20 and the lava and tuff of Deadhorse Flat. Brief descriptions of these units, based on cores and cuttings, are given in table 1.

Most ash-fall and nonwelded ash-flow tuffs in the saturated zone are zeolitized (glassy fragments are altered to zeolites), and some are argillized; reworked tuffs and volcanic conglomerates, sandstones, and siltstones often are silicified. Vitric tuffs, in which glass shards are unaltered, are more common in postcaldera units that occur above the saturated zone.

Total porosity of cores of ash-fall and nonwelded ash-flow tuffs ranges from 12 to slightly more than 50 percent. The average total porosity from 84 core samples of these rocks of the tuffs and rhyolites of Area 20 is 26 percent; porosity of similar rocks from the lava and tuff of Deadhorse Flat and from the Paintbrush Tuff averages more than 35 percent (table 5). There is a nonuniform decrease in porosity to a depth of more than 6,000 feet; however, porosity decreases rapidly below a depth of 7,000 feet. In the UE-20f exploratory hole, ash-fall and nonwelded to slightly welded ash-flow tuffs to a depth of 7,000 feet have total porosities ranging from 25 to 32 percent; from 7,000 feet to 11,000 feet total porosities range from 11 to 16 percent (R. D. Carroll, written commun., 1965).

Samples of ash-fall tuff assigned to informal local units in the U-12e and U-12b tunnel systems under Rainier Mesa, east of Pahute Mesa, were analyzed for interstitial porosity and interstitial permeability (Thordarson, 1965). The interstitial porosity of the zeolitic tuff ranged from 25 to 38 percent; interstitial permeability ranged from 0.0004 to $0.02 \mathrm{gpd}$ per square foot. The interstitial porosity and permeability of vitric tuff were high compared with those of zeolitic tuff.

Fracture frequencies in cores of ash-fall and nonwelded ash-flow tuffs ranged from 0.0 to 2.0 fractures per foot of core. The average from 82 cores, less than 0.2 fracture per foot, is considerably lower than the average fracture frequencies for rhyolitic lava flows and densely welded tuff, which develop fracture systems upon cooling and shrinking. Further, the fractures in the incompetent ash-fall and nonwelded ash-flow tuffs commonly are resealed. 
TABLE 5. - Summary of porosity and fracture frequency in core samples of ash-fall and nonwelded ash-flow tuffs [Compiled from unpublished data prepared by U.S. Geological Survey]

\begin{tabular}{|c|c|c|c|c|c|c|}
\hline Formation & $\begin{array}{c}\text { Exploratory } \\
\text { hole and, in } \\
\text { parentheses, } \\
\text { number of cores }\end{array}$ & $\begin{array}{c}\text { Number } \\
\text { of } \\
\text { cores }\end{array}$ & $\begin{array}{c}\text { Range in } \\
\text { total } \\
\text { porosity } \\
\text { (percent) }\end{array}$ & $\begin{array}{l}\text { Average } \\
\text { total } \\
\text { porosity } \\
\text { (percent) }\end{array}$ & $\begin{array}{c}\text { Range in } \\
\text { number of } \\
\text { fractures } \\
\text { per } \mathrm{ft}\end{array}$ & $\begin{array}{c}\text { Average } \\
\text { number of } \\
\text { fractures } \\
\text { per } \mathrm{ft}\end{array}$ \\
\hline Paintbrush Tuff & $\begin{array}{l}\text { UE-19c (1), } \\
\text { UE-19gs (1), } \\
\text { UE-19h (1), } \\
\text { UE-19i (3), } \\
\text { UE-20c (2), } \\
\text { UE-20d (4), } \\
\text { UE-20f (1) }\end{array}$ & 13 & $28.0-44.9$ & 35.5 & $0.0-0.3$ & 0.07 \\
\hline $\begin{array}{l}\text { Tuffs and rhyolites } \\
\text { of Area } 20 \text {. }\end{array}$ & $\begin{array}{l}\text { UE-19e (4), } \\
\text { UE-19fs (5), } \\
\text { UE-19gs (3), } \\
\text { UE-19h (2), } \\
\text { PM-1 (9), } \\
\text { U-20a (5), } \\
\text { UE-20c (9), } \\
\text { UE-20d (8), } \\
\text { UE-20e-1 (18), } \\
\text { UE-20f (10), } \\
\text { UE-20h (10), } \\
\text { UE-20j (1) }\end{array}$ & 84 & $12.3-43.9$ & 26.2 & $.0-1.4$ & .18 \\
\hline $\begin{array}{l}\text { Lava and tuff of } \\
\text { Deadhorse Flat. }\end{array}$ & $\begin{array}{l}\text { UE-19c (1), } \\
\text { UE-19e (2) }\end{array}$ & 3 & $29.6-50.3$ & 37.7 & $.0-.1$ & $<.10$ \\
\hline Belted Range Tuff & $\begin{array}{l}\text { UE-19c (1), } \\
\text { UE-19d (1), } \\
\text { PM-2 (9), } \\
\text { UE-20j (1) }\end{array}$ & 12 & $19.4-38.6$ & 28.3 & $.0-.3$ & .06 \\
\hline
\end{tabular}

Dips in cores of bedded tuffs are usually erratic and range from $0^{\circ}$ to $90^{\circ}$. These dips may reflect irregular depositional surfaces or slump features.

The resistivities of relatively impermeable zeolitized tuffs are generally less than $100 \mathrm{ohm}$-meters on the short normal curve on electric logs made in drill holes at Pahute Mesa. Resistivities of vitric ash-fall tuff, nonwelded to slightly welded ash-flow tuff, and tuffaceous sediments are similar to those of the zeolitized units. The lowest resistivities occur in intervals that have been altered by argillization; these intervals, from hydraulic testing data, are the least permeable.

Bedded tuff and nonwelded tuff generally are indicated on the curves of caliper logs by large "washedout" or caved intervals; hole size is generally greater than drill-bit size. Prominent ledges and abrupt "washed-out" zones commonly occur at the contact of these rocks with the more competent rhyolitic lava flows and densely welded tuffs.

CHARACTERISTICS BASED ON HYDRAULIC TESTS

Zeolitized bedded tuff was the principal rock in $\mathbf{5 4}$ intervals isolated by straddle packers in drill holes and tested by adding or withdrawing water; these intervals ranged in thickness from 150 to 200 feet. Relative specific capacities in 41 of the intervals tested ( 76 percent of the total) ranged from less than 0.001 to $0.02 \mathrm{gpm}$ per foot of drawdown (fig. 4). Intervals with relative specific capacities that ranged from 0.05 to $0.5 \mathrm{gpm}$ per foot of drawdown were measured only in UE-20h and UE-20j drill holes. In general, the highly argillized intervals were the least permeable.

\section{REGIONAL MOVEMENT OF GROUND WATER}

Ground water beneath Pahute Mesa moves southwestward and southward toward the Amargosa Desert through Oasis Valley, Crater Flat, and western Jackass Flats. (See pl. 3.) This area is considered part of a single ground-water basin informally designated by Winograd, Thordarson, and Young (1971) as the Oasis Valley-Fortymile Canyon basin.

The Oasis Valley-Fortymile Canyon ground-water basin comprises an area of intense late Miocene and early Pliocene volcanism. The Silent Canyon and Timber Mountain calderas are the principal volcanotectonic structural basins in the area; the younger Timber Mountain caldera, including its moat area, occupies most of the southern two-thirds of the ground-water basin. The Black Mountain caldera (Christiansen and Noble, 1965). lies west of the Silent Canyon caldera, and several other calderas have been mapped in the surrounding area. Volcanic cones project above the alluvial fill in Crater Flat.

Paleozoic carbonate rocks may underlie volcanic rocks beyond the ring fractures of the calderas, but they probably do not underlie the volcanic rocks within the calderas; and if carbonate rocks underlie the moat areas, they would be found at great depths below land surface. For this reason, it does not appear that the carbonate aquifer in western Yucca 
Flat and northern Jackass Flats has lateral continuity with carbonate rocks that may underlie areas outside the calderas.

The hydrologic limits of the basin are not fully defined and probably do not correspond everywhere with the surface-drainage boundaries. Highly impermeable clastic rocks underlie the topographic divide that trends southward along the Belted Range (pl. 3). The eastern limits of the basin probably coincide with this divide. The western limits of the basin at Pahute Mesa may coincide with the west margin of Gold Flat in the area of Quartz Mountain.

The ground-water gradient to the southwest at Pahute Mesa is interrupted by a barrier (pl. 1) which trends parallel to the north-northeast strike of basin-and-range faulting. The exact strike and full linear extension of this barrier are not firmly established. Seismic studies after some nuclear explosions have disclosed aftershock epicenters along the barrier lineament. Some of the epicenters are several miles south of the intersection of the Silent Canyon and Timber Mountain calderas, beyond the south end of the barrier as shown on plate 1; hence, the barrier may project farther into the moat area of the Timber Mountain caldera. Part of the barrier coincides with the western ring-fracture system of the Silent Canyon caldera. A ground-water drain parallels the barrier on the east and is possibly con-

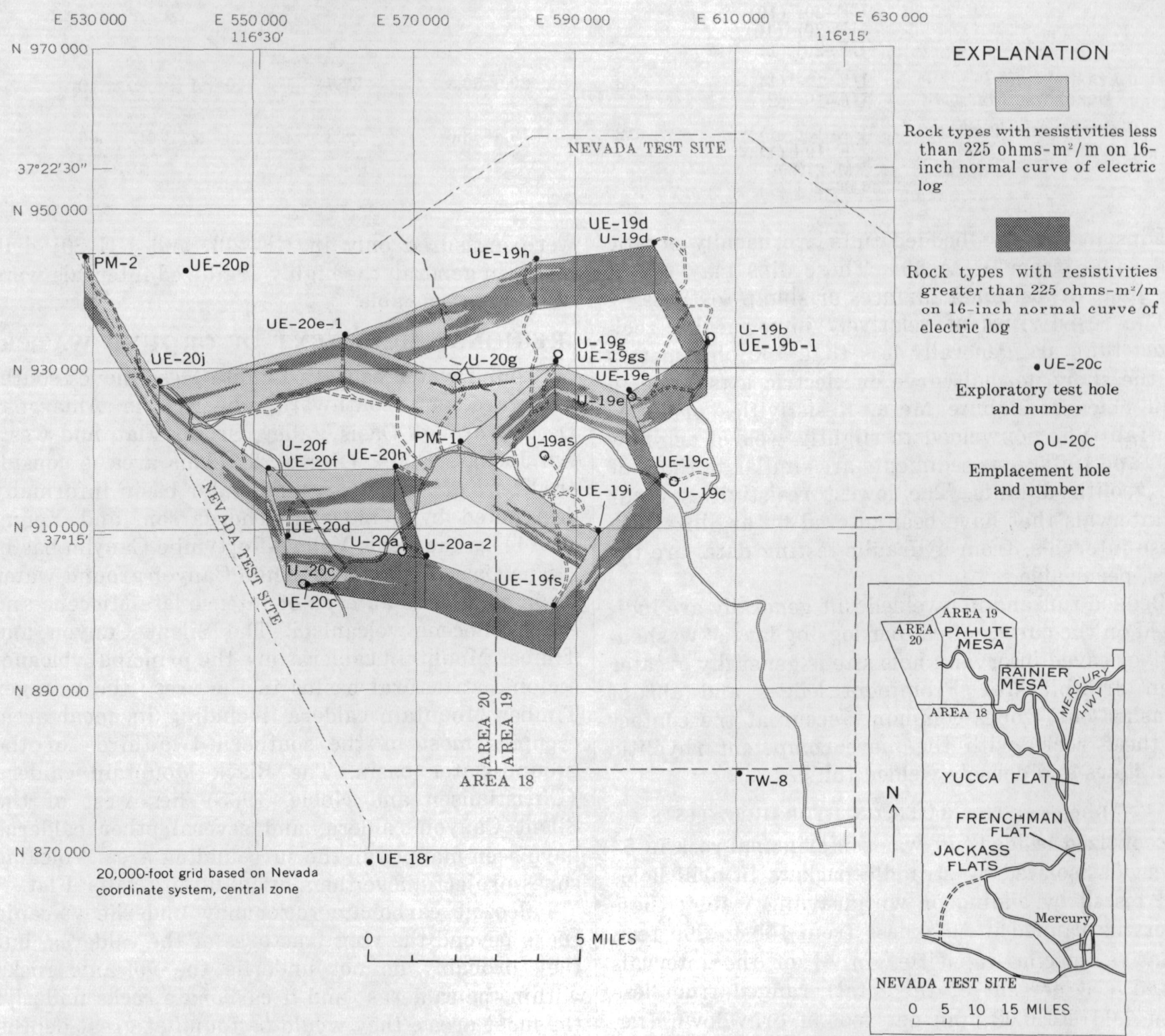

FIGURE 8. - Resistivity of rocks in upper 2,000 feet of saturated zone. 
trolled by the caldera ring fractures. The hydraulic gradient west of the barrier is southeastward, and leakage occurs across the barrier into the drain.

\section{ESTIMATES OF UNDERFLOW BENEATH PAHUTE MESA}

Ground water moves in volcanic rocks beneath Pahute Mesa through interconnecting faults and joints. As many as 10 faults per square mile have been mapped on the surface in postcaldera ashflows that mask the structural basin. The density of faults in intracaldera rocks probably is many times greater.

The highly complicated structure and distribution of different rocks in the subsurface result in great variations in transmissivities over short distances. The fence diagram (fig. 8), compiled from interpretation of resistivity data obtained from 16-inch normal curves of electric logs made in drill holes, shows the distribution of rocks in the upper 2,000 feet of the saturated zone. Rocks with resistivities less than $225 \mathrm{ohm}$-meters include zeolitized and bedded ashfall tuff, tuffaceous sediments, and nonwelded and partly welded ash-flow tuff. Rocks with resistivities greater than $225 \mathrm{ohm}$-meters include rhyolitic lava flows, vitrophyre, and densely welded tuff. Greatest transmissivities were measured in holes drilled along the east margin of the Silent Canyon caldera, where the principal rock in the saturated zone is rhyolitic lava (table 3 and fig. 9).

Transmissivities, based on data from single wells that were pumped on Pahute Mesa for periods of 12 to 47 hours, range from 1,400 to 140,000 gpd per $\mathrm{ft}$. Because of these extreme values, a geometric mean, rather than an arithmetic mean, is considered to yield a more reasonable value for average transmissivity. A geometric mean of $10,000 \mathrm{gpd}$ per $\mathrm{ft}$ is used for calculation of underflow.

Data from hydraulic tests in drill holes, especially from radioactive-tracer surveys, indicate the complexity of flow patterns beneath the mesa. These radioactive-tracer surveys show that most water is yielded from fractured zones that constitute only 3 to 10 percent of the total section penetrated in the saturated zone. Further, the depths at which these fractured zones occur are highly variable and are not always correlative between holes that are drilled even as close as 100 feet apart.

Despite the tortuous flow patterns and changes in head potentials with depth, discussed under "Head Changes in Drill Holes," ground-water flow beneath Pahute Mesa is essentially lateral with potential for downward leakage in the eastern part of the caldera and upward leakage in the western part. The hydraulic gradient ranges from 25 to 100 feet per mile (pl. 1) ; a gradient of 50 feet per mile is used to compute underflow from Pahute Mesa.

The equation for computing underflow per mile of flow-section width is $Q=0.00112 T I$, where $Q$ is the quantity of underflow, in acre-feet per year; 0.00112 is the factor for conversion of gallons per day to acre-feet per year; $T$ is the transmissivity, in gallons per day per foot; and $I$ is the ground-water gradient, in feet per mile. By using the values for transmissivity (table 3) and gradient (preceding paragraph) given above, the estimated underflow beneath Pahute Mesa is 560 acre-feet per mile per year. The length of underflow strip, about 15 miles, is the approximate distance between the hydraulic barrier on the west and the ground-water divide on the east-near test well TW-8. The total estimated underflow passing southwestward beneath Pahute Mesa is about 8,000 acre-feet per year.

\section{ESTIMATED ANNUAL RECHARgE FROM PRECIPITATION AND UNDERFLOW}

Precipitation in southern Nevada depends to a large extent upon altitude and location (R. F. Quiring, U.S. Weather Bur., written commun., 1965). Pahute Mesa lies principally within a transition zone approximately 50 miles wide, with a deficit-precipitation zone to the west and an excess-precipitation zone to the east. It has a precipitation-altitude relation as shown in table 6 .

An estimate of potential recharge to the groundwater reservoir beneath eastern Pahute Mesa and adjacent areas was made by using the method devised by Eakin and others (1951). The methor entails measurements of areas in which the average annual precipitation ranges between specific limits; a percentage of the average annual precipitation on each area represents the recharge to the groundwater reservoir from that area. Percentages of annual precipitation used for computing potential recharge are listed in table 6 . The area planimetered for estimation of potential recharge to the groundwater reservoir lies within the coordinates of lat $37^{\circ} 10^{\prime} \mathrm{N}$. and $37^{\circ} 22^{\prime} \mathrm{N}$. and long $116^{\circ} 12^{\prime} \mathrm{W}$. and $116^{\circ} 33^{\prime}$ W. (See pl. 3.)

The recharge to the ground-water reservoir beneath Pahute Mesa from precipitation may be greater or less than the estimated annual potential recharge because of the complicated structure and rock types. Welded tuffs that occur on the surface over most of the mesa are highly fractured; however, percolation of water to the deep water table may be restricted by intervals of poorly permeable bedded or nonwelded tuffs that range in thickness from 200 to more than 600 feet. In a few holes that were drilled with air as the circulating medium, 


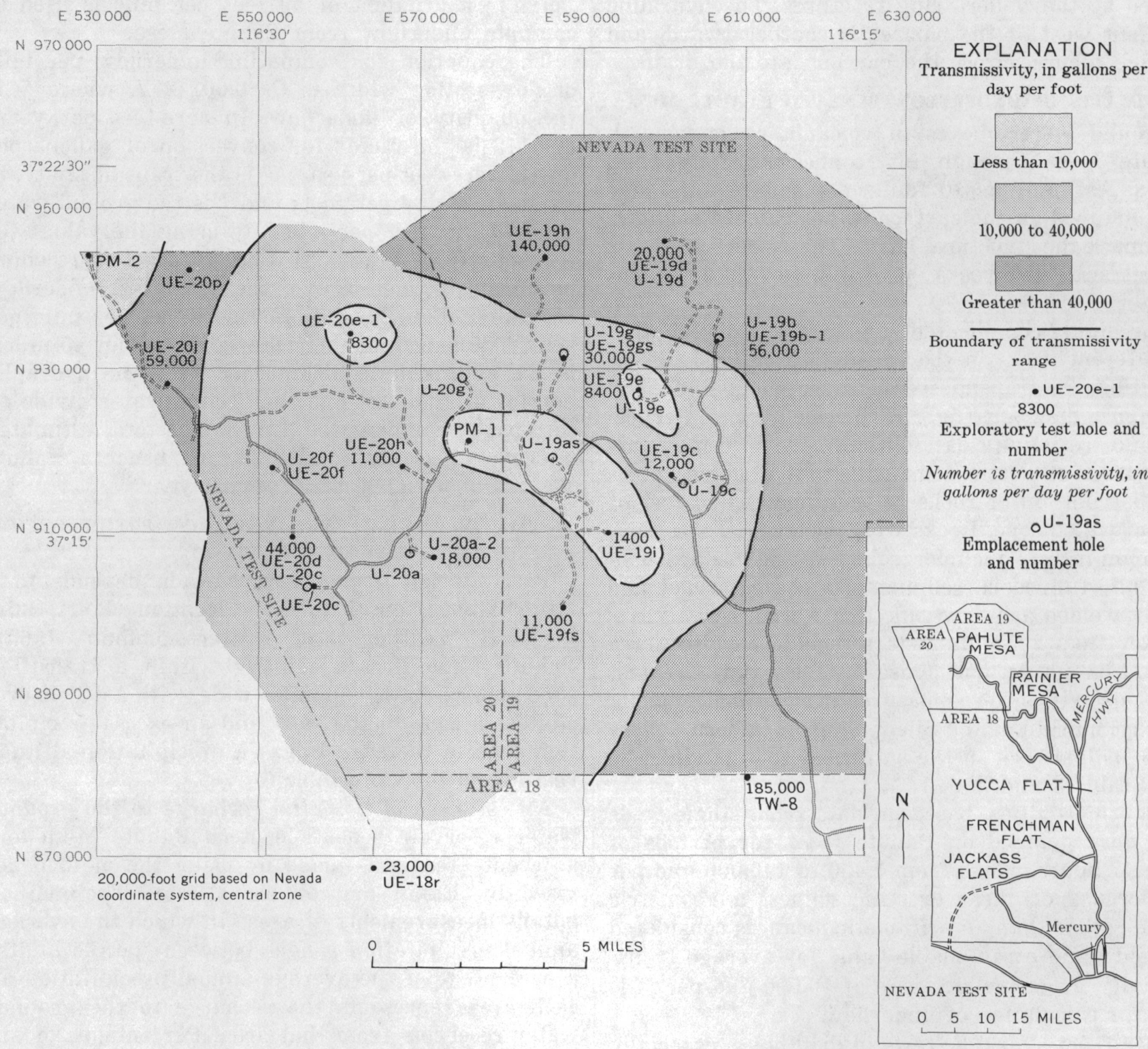

FIGURE 9. - Ranges of transmissivity.

perched or semiperched water was detected at depths of 500 or more feet. Conversely, in the eastern part of the mesa, where rhyolite is the principal rock type in the subsurface, vertical permeability through fractures may be great, and precipitation may contribute considerably to recharge.

Estimates of average annual potential recharge to Kawich Valley and Gold Flat are 3,500 acre-feet and 1,600 acre-feet, respectively (Eakin and others, 1963). As much as 1,000 acre-feet may enter Kawich Valley as underflow from the north, and 2,000 acrefeet may enter Gold Flat from the north. Most of the ground water from Kawich Valley probably moves into the eastern part of Pahute Mesa; pos- sibly one-third of the underflow from Gold Flat may enter the ground-water system beneath part of Pahute Mesa (pl. 3). On the basis of conservative estimates, about 5,500 acre-feet of underflow from these areas enters the ground-water system beneath the mesa. Including the average annual potential recharge from precipitation, the total volume of recharge is about 8,000 acre-feet.

\section{ESTIMATED ANNUAL DISCHARGE}

From Pahute Mesa, ground water moves southwestward and southward toward the Amargosa Desert through Oasis Valley, Crater Flat, and western Jackass Flats (pl. 3).

Malmberg and Eakin (1962) estimated the total 
TABLE 6. - Estimated average annual ground-water potential recharge from precipitation at Pahute Mesa and Rainier Mesa

\begin{tabular}{|c|c|c|c|c|c|}
\hline $\begin{array}{l}\text { Precipitation } \\
\text { zone } \\
\text { (in.) }\end{array}$ & $\begin{array}{c}\text { Altitude of } \\
\text { zone } \\
(\mathrm{ft})\end{array}$ & $\begin{array}{c}\text { Area of } \\
\text { zone } \\
\text { (acres) }\end{array}$ & $\begin{array}{c}\text { Precipitation } \\
\text { (acre-ft } \\
\text { per yr) }\end{array}$ & $\begin{array}{c}\text { Estimated } \\
\text { recharge } \\
\text { (percent) }\end{array}$ & $\begin{array}{c}\text { Estimated } \\
\text { recharge } \\
\text { (acre-ft per yr) }\end{array}$ \\
\hline 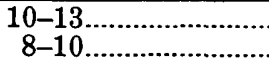 & $\begin{array}{l}7,000-8,000 \\
6,000-7,000\end{array}$ & $\begin{array}{l}25,000 \\
95,000\end{array}$ & $\begin{array}{l}25,000 \\
71,000\end{array}$ & $\begin{array}{l}7 \\
2\end{array}$ & $\begin{array}{l}1,750 \\
1,400\end{array}$ \\
\hline Total..... & & 120,000 & 96,000 & $\ldots$ & 3,150 \\
\hline
\end{tabular}

average annual ground-water discharge from Oasis Valley by evapotranspiration and subsurface outflow to be about 2,400 acre-feet. Recent studies in Oasis Valley made by W. A. Beetem and R. A. Young, U.S. Geological Survey, indicate that the discharge from Oasis Valley might be two or more times greater than the estimates by Malmberg and Eakin (W. A. Beetem, oral commun., 1968).

Minor eastward underflow may occur across the ground-water divide into Yucca Flat. The annual inflow into Yucca Flat probably does not exceed 200 acre-feet (Winograd and others, 1971). Therefore, of the estimated 8,000 acre-feet of underflow beneath the south margin of Pahute Mesa, possibly as much as 5,000 acre-feet moves toward the Amargosa Desert through Crater Flat and western Jackass Flats.

As much as 2,000 acre-feet of potential recharge to the ground-water system results from precipitation at Timber Mountain, Buckboard Mesa, western Jackass Flats, and Crater Flat. Hence, the total discharge to the Amargosa Desert is about 10,000 acre-feet.

\section{LOCAL MOVEMENT OF GROUND WATER}

The depth to water under the eastern part of Pahute Mesa and within the limits of the Silent Canyon caldera ranges from about 1,950 feet (alt $4,160 \mathrm{ft}$ ) in the western part to 2,350 feet (alt 4,685 $\mathrm{ft}$ ) in the eastern part. In the extreme northwestern part of the Nevada Test Site (pl. 1), outside the caldera, the depth to water is about 850 feet (alt $4,700 \mathrm{ft}$ ).

Geologic structure, spatial distribution of tuff and rhyolitic lava flows, and location of recharge areas are major factors contributing to the complex flow patterns interpreted from drill-hole data on the mesa. Geologic structure and the distribution of major rock types in the subsurface are shown on plates 1 and 2 and in figure 8 .

Head changes with drilled depth are stable or decline in all but one of the holes drilled in the eastern part of the report area; head changes with drilled depth are variable or increasing in holes drilled in the western part of the report area. Head changes in drill holes are summarized in figure 10 and listed in table 7 .
HEAD CHANGES IN DRILL HOLES

Rhyolitic lavas are relatively competent rocks; hence, compressibility of these rocks is moderate, and faults and joints may remain open even at great depths. Horizontal nermeability occurs along flow layers and fractures; vertical permeability occurs only along fractures. In most of the drill holes in the eastern part of the caldera, where rhyolitic lava flows comprise 90 to 100 percent of the rock section in the saturated zone, heads are relatively stable through depths ranging to 2,500 feet below the top of the saturated zone; heads decrease, or probably decrease, below these relatively stable intervals to total drilled depth. Ground water flows essentially laterally; however, the flow paths probably are tortuous in that most of the water flows through zones of fracture permeability that are randomly distributed and comprise only 3 to 10 percent of the drilled section. Water leaks downward along fractures to depths greater than 6,000 feet below the top of the saturated zone. Other factors that influence the flow pattern in this area are: (1) Underflow from Kawich Valley which enters from the northeast, and (2) recharge from precipitation which enters the saturated zone from higher altitudes on the east.

Rhyolitic lava flows of the lava and tuff of Deadhorse Flat, that flooded the eastern part of the caldera, pinch out abruptly to the west where they interfinger with ash-fall and ash-flow tuffs. Where the percentage of rhyolitic lava flows decreases, head changes with depth in drill holes are less pronounced, and a transition zone between decreasing heads with depth and increasing head with depth is approached. A reduction in vertical permeability occurs where lava flows interfinger with tuffs. Hence, vertical permeability is a major factor controlling the pattern of head changes with depth beneath Pahute Mesa.

Isolated structural highs, consisting mostly of tuff, were present along the east margin of the caldera during eruption of the lava flows. Areas with a low percentage of rhyolitic lava in the saturated zone were penetrated by drill holes UE-19e and UE-19i (table 2 and fig. 3). The areal extent of the high penetrated in the UE-19e hole probably was minor; heads in this hole decrease with depth, as do the heads in surrounding drill holes where the section 
consisted mostly of rhyolitic lavas. Tuffs in the area of UE-19i were of greater areal extent; UE-19i was the only drill hole in the eastern part of the caldera in which heads increased with depth.

Ash-fall and ash-flow tuffs comprise the greatest percentage of the rock section in the upper 2,000 feet of the saturated zone in drill holes in the western and central parts of the caldera. Rhyolitic lavas account for less than 1 to 22 percent of the total section; exceptions are drill holes U-20a-2 and $\mathrm{UE}-20 \mathrm{~h}$, in which a regional nose of rhyolitic lavas, thinning northward, was penetrated.

The rhyolitic lavas in the western and central parts of the caldera are lenticular bodies of variable thickness. These lava flows are separated by thick sections of ash-fall and ash-flow tuffs that have low permeabilities. The tuffs are relatively incompetent and, hence, are more sensitive than the rhyolitic lavas to compression by weight of rock overburden. Fractures are more likely to be resealed, volume and porosity are reduced, and pressures are increased. Vertical permeability in some areas may be low enough to create confined aquifers.

In holes drilled in the western and central parts of the caldera, heads usually are variable from the top of the saturated zone through intervals of rhyolitic lava flows that have high permeabilities and then increase with depth to the total drilled depth. Ground-water flow is essentially lateral with upward leakage.

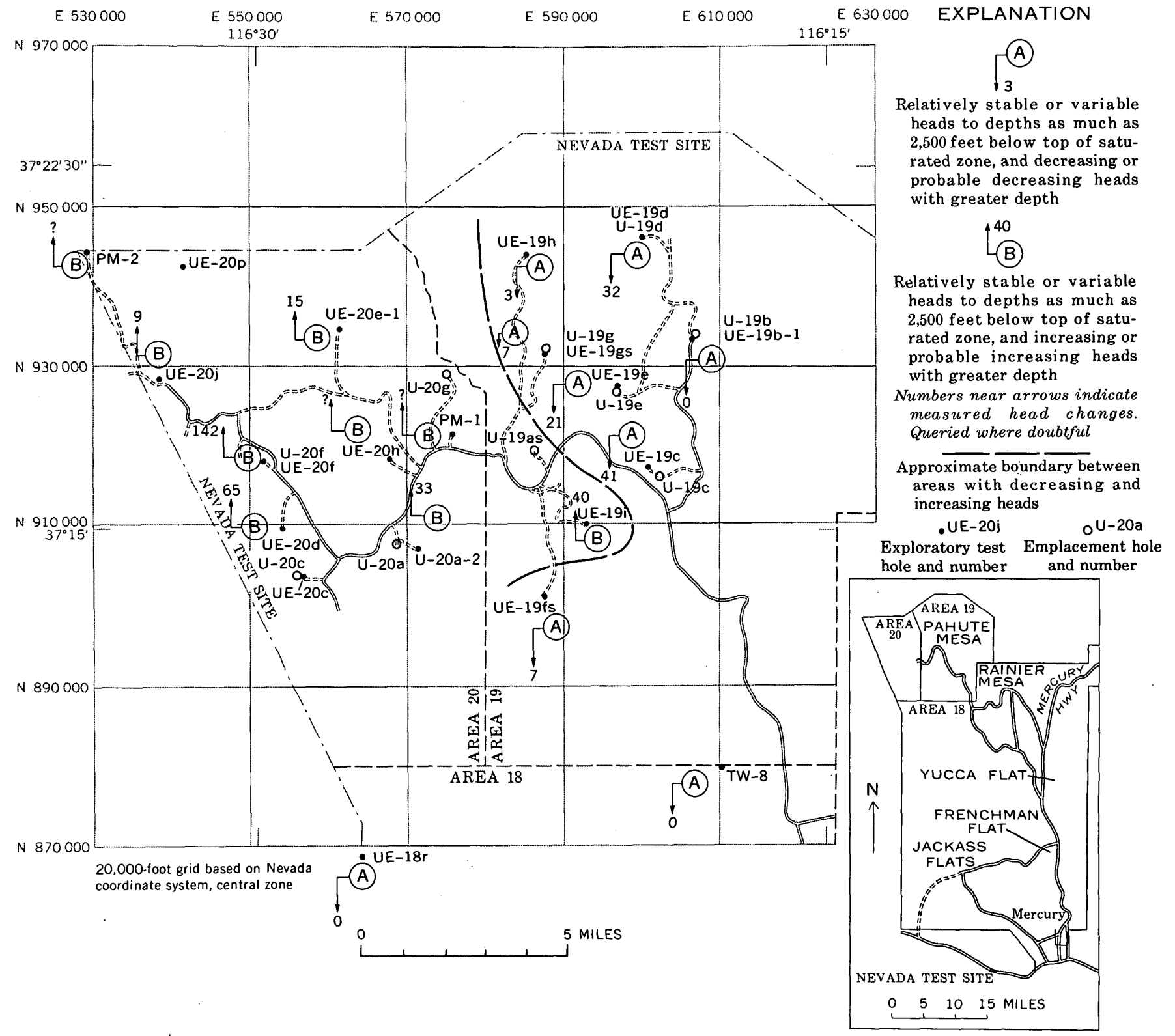

Figure 10. - Head changes with depth in exploratory test holes. 
TABLE 7. - Head changes with depth in exploratory holes, Pahute Mesa [All depths in feet below land surface. Intervals isolated with packers in PM-1 and PM-2 were too impermeable to yield data

\begin{tabular}{|c|c|c|c|c|c|}
\hline $\begin{array}{c}\text { Exploratory } \\
\text { hole }\end{array}$ & $\begin{array}{l}\text { Depth to } \\
\text { water in } \\
\text { open hole }\end{array}$ & $\begin{array}{c}\text { Interval (s) } \\
\text { isolated with } \\
\text { packers }\end{array}$ & $\begin{array}{c}\text { Depth to water } \\
\text { for isolated } \\
\text { interval (s) }\end{array}$ & $\begin{array}{c}\text { Principal rock types } \\
\text { in isolated } \\
\text { interval (s) }\end{array}$ & $\begin{array}{c}\text { Depth of interval (s) } \\
\text { with highest } \\
\text { permeability }\end{array}$ \\
\hline UE-19b-1................. & 2,117 & $2,176-4,060$ & 2,117 & 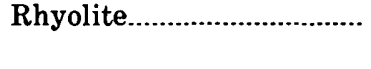 & $\begin{array}{r}2,610-2,640 \\
2,720-2,760\end{array}$ \\
\hline \multirow[t]{2}{*}{ 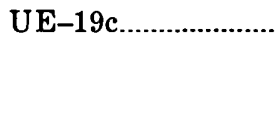 } & \multirow[t]{2}{*}{2,345} & & $2,319(?)$ & \multirow{2}{*}{$\begin{array}{l}\text { Rhyolite and rhyolite } \\
\text { breccia. }\end{array}$} & \multirow[b]{2}{*}{$3,050-3,075$} \\
\hline & & $\begin{array}{l}2,884-3,284 \\
4,033-4,231\end{array}$ & $\begin{array}{l}2,348 \\
2,360\end{array}$ & & \\
\hline 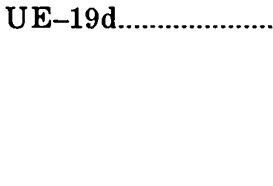 & 2,177 & $\begin{array}{l}2,500-3,483 \\
3,472-3,852 \\
3,844-4,042 \\
4,626-4,784 \\
4,810-4,968 \\
5,823-6,583\end{array}$ & $\begin{array}{l}2,177 \\
2,186 \\
2,178 \\
2,180 \\
2,200 \\
2,210\end{array}$ & $\begin{array}{l}\text { Rhyolite } \\
\ldots \text {........do do do }\end{array}$ & $3,300-3,350$ \\
\hline \multirow[t]{2}{*}{ UE-19e....................... } & \multirow[t]{2}{*}{2,240} & $2,619-2,779$ & 2,232 & \multirow{2}{*}{$\begin{array}{l}\text { Welded tuff and } \\
\text { zeolitized tuff. }\end{array}$} & \multirow{2}{*}{$\begin{array}{r}2,650-2,690 \\
4,970-4,990\end{array}$} \\
\hline & & $4,802-6,004$ & 2,253 & & \\
\hline UE-19fs............................ & 2,305 & $\begin{array}{l}2,750-3,218 \\
3,520-3,838 \\
4,146-4,480\end{array}$ & $\begin{array}{l}2,302 \\
2,304 \\
2,309\end{array}$ & 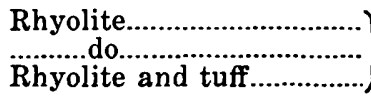 & $\begin{array}{r}2,880-2,950 \\
3,150-3,160\end{array}$ \\
\hline UE-19gs................... & 2,045 & $\begin{array}{l}2,802-2,970 \\
4,636-4,834 \\
6,920-7,118\end{array}$ & $\begin{array}{l}2,043 \\
2,050 \\
2,049\end{array}$ & 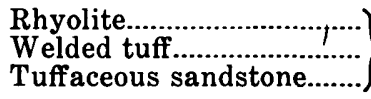 & $\begin{array}{r}2,940-2,970 \\
4,786-4,790\end{array}$ \\
\hline 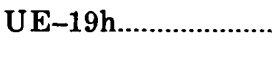 & 2,112 & $\begin{array}{l}2,200-2,396 \\
2,408-3,705\end{array}$ & $\begin{array}{l}2,109 \\
2,112\end{array}$ & Rhyolite and welded tuff & $\begin{array}{l}2,378-2,388 \\
\text { (est.) }\end{array}$ \\
\hline UE-19i......................... & 2,258 & $\begin{array}{l}2,910-3,068 \\
3,460-3,618 \\
4,100-4,258\end{array}$ & $\begin{array}{l}2,220 \\
2,258 \\
2,218\end{array}$ & 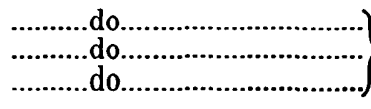 & $\begin{array}{r}3,400-3,470 \\
3,750-3,765\end{array}$ \\
\hline $\mathrm{U}-20 \mathrm{a}-2 \ldots \ldots \ldots \ldots$ & 2,066 & $\begin{array}{l}2,067-2,608 \\
2,492-2,682 \\
2,895-3,085 \\
3,090-3,280 \\
3,648-3,838 \\
4,048-4,238 \\
4,355-4,500\end{array}$ & $\begin{array}{l}2,064 \\
2,066 \\
2,065 \\
2,064 \\
2,042 \\
2,051 \\
2,033\end{array}$ & 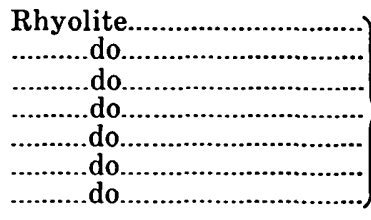 & $\begin{array}{r}2,400-2,682, \\
2,895-3,085 \\
3,648-3,838\end{array}$ \\
\hline 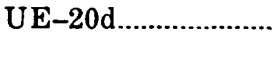 & 2,075 & $\begin{array}{l}2,578-2,776 \\
4,118-4,316\end{array}$ & $\begin{array}{l}2,078 \\
2,013\end{array}$ & 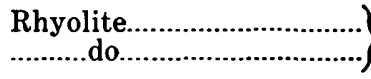 & $2,578-2,730$ \\
\hline \multirow[t]{2}{*}{$\mathrm{UE}-20 \mathrm{e}-1 \ldots \ldots \ldots \ldots$} & \multirow[t]{2}{*}{1,822} & $\begin{array}{l}2,774-2,972 \\
3,480-3,678 \\
4,020-4,218\end{array}$ & $\begin{array}{l}1,828 \\
1,835 \\
1,828\end{array}$ & \multirow{2}{*}{$\begin{array}{l}\text { Rhyolite..................... } \\
\text { Rhyolite and vitrophyre } \\
\text { Zeolitized bedded tuff } \\
\text { and welded tuff. }\end{array}$} & \multirow[t]{2}{*}{$3,550-3,660$} \\
\hline & & $4,540-6,395$ & 1,820 & & \\
\hline 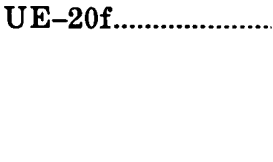 & ${ }^{1} 1,954$ & $\begin{array}{l}2,598-2,796 \\
3,150-3,348 \\
3,338-3,536 \\
4,350-5,249 \\
8,972-9,170\end{array}$ & $\begin{array}{l}1,946 \\
1,988 \\
1,954 \\
1,857 \\
1,846\end{array}$ & 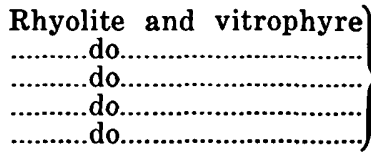 & $\begin{array}{r}3,150-3,348 \\
4,568-4,766\end{array}$ \\
\hline 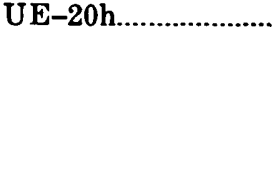 & 2,116 & $\begin{array}{l}2,575-2,743 \\
2,741-3,210 \\
3,350-3,518 \\
3,705-3,873 \\
3,892-4,060 \\
4,070-4,238\end{array}$ & $\begin{array}{l}2,111 \\
2,116 \\
2,111 \\
2,114 \\
2,116 \\
2,117\end{array}$ & 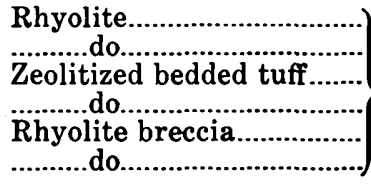 & $\begin{array}{r}3,042-3,170 \\
4,040-4,060\end{array}$ \\
\hline UE-20j............................ & 1,270 & $\begin{array}{l}1,858-2,056 \\
2,051-2,249 \\
2,253-2,461 \\
2,670-2,868 \\
2,957-3,155 \\
3,359-3,832 \\
4,023-5,690\end{array}$ & $\begin{array}{l}1,245 \\
1,247 \\
1,249 \\
1,261 \\
1,270 \\
1,273 \\
1,264\end{array}$ & 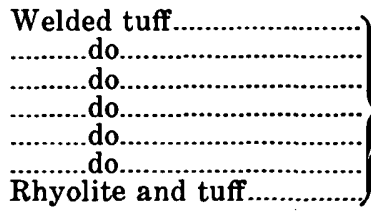 & $\begin{array}{r}2,060-2,150 \\
2,957-3,557\end{array}$ \\
\hline UE-18r' ${ }^{2} \ldots \ldots \ldots \ldots \ldots$ & 1,372 & $1,440-5,004$ & 1,372 & 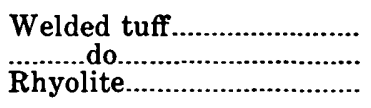 & $\begin{array}{l}1,660-1,675 \\
2,350-2,360 \\
3,550-3,560\end{array}$ \\
\hline $\mathrm{TW}-8^{2} \ldots \ldots \ldots \ldots \ldots$ & 1,068 & $1,320-5,490$ & 1,068 & Rhyolite and welded tuff & $1,290-2,010$ \\
\hline
\end{tabular}




\section{RELATION BETWEEN SUBSURFACE TEMPERATURES AND FLOW PATTERNS}

Geothermal gradients, listed in table 8, were computed by dividing the difference between the bottom-hole temperature and the mean annual air temperature by the depth at which the bottom-hole temperature was obtained. Because of caving, sloughing, or other poor hole conditions, the bottom-hole temperatures were not always obtained at the total drilled depth. Temperature logs were made several hours or days after completion of the drilling and, hence, represent transient rather than equilibrium temperatures. However, the data are considered sufficiently accurate to establish the relation between temperature and flow pattern. Geothermal gradients (Levorsen, 1954) are expressed in degrees Celsius per 100 feet.

Temperatures in the subsurface do not appear to contribute to head differences with depth in holes drilled within the boundaries of the Silent Canyon caldera at Pahute Mesa. There is a relation, however, between temperatures and head changes in drill holes. Thermal gradients are lowest in those holes where relatively stable heads occur; gradients are highest where the differences in heads are greatest, irrespective of the direction of head change. If the maximum head changes are equivalent, thermal gradients in holes having heads that increase with depth may be quite similar to those in holes having heads that decrease with depth. (See table 8.)

Exploratory drill holes PM-2 and UE-20j are west of the Silent Canyon caldera. The high geothermal gradient of $1.31^{\circ} \mathrm{C}$ per 100 feet in PM-2 probably results from remnant heat in a massive granitic intrusive body that was penetrated below a depth of 8,400 feet.

\section{WATER-LEVEL CONTOUR MAP}

The water-level data used to construct the waterlevel contour map (pl. 1) represent the composite level of several water-bearing zones in each hole. The lenticularity and random vertical distribution of rhyolitic lava flows and ash-fall and ash-flow tuffs in the saturated zone in the caldera preclude any distinction and correlation between water levels of different aquifers in the various wells. Inaccuracies in the map exist because of head differences with increasing depth and the differing depths of drill holes; nevertheless, the map reflects the hydraulic gradient and direction of ground-water flow under the eastern part of Pahute Mesa.

Composite water levels from wells drilled in the eastern part of the Silent Canyon caldera are considered more reliable than those from wells drilled in the western part. Depths of exploratory holes in the eastern part range from 3,700 to 8,489 feet. Composite water levels either remained constant or decreased only slightly during drilling of the deeper holes. Depths of exploratory holes in the western and central parts of the caldera range from 4,500 to 13,686 feet. Composite water levels fluctuated during drilling and generally rose with increasing depth. A head difference in excess of 142 feet was measured in the deepest hole drilled in the area; for uniformity, a composite water level obtained after that well was drilled to a depth of 4,500 feet was used for construction of the water-level contour map.

Local variations in ground-water flow lines probably are very common because of the heterogeneous rock section and the prevalence of faults which cause differences in conditions of local confinement. The hydraulic gradient is to the southwest and to the southeast toward a north-south trending drain; it is quite flat in the eastern part of the caldera but steepens in the western part.

A definite relation exists between the slope of the hydraulic gradient and the subsurface geology. In the eastern part of the caldera, where the gradient is gentle, principal rocks in the saturated zone are rhyolitic lava flows. The flat area in the central part of the caldera, between exploratory holes U-20a-2, UE-20h, and PM-1, reflects the nose of a rhyolitic lava flow in the subsurface that has an axis striking roughly between holes U-20a-2 and UE-20h. The flat area also occurs in the area of a major northstriking horst that bisects the caldera. The steepening of the hydraulic gradient in the western part of the caldera corresponds to an increase in the percentage of poorly permeable zeolitized tuff in the saturated zone.

The caldera boundary fault on the west brings into juxtaposition the intracaldera rocks with precaldera rocks having lower permeabilities, thus creating a limited barrier to the flow of ground water.

\section{GROUND-WATER VELOCITY}

Ground-water velocity, $V$, beneath Pahute Mesa was estimated using the equation $V=Q / A p$, where $Q$ is the underflow, in cubic feet per day; $A$ is the cross-sectional area of flow, in square feet; and $p$ is fracture and interstitial porosity. The value for $Q$, based on data presented earlier in this report, is 8,000 acre-feet per year, or about $1 \times 10^{6}$ cubic feet per day. The area of underflow $(A)$ used in the computation is assumed to be 15 miles long and 3,500 feet thick, or $277 \times 10^{\text {f }}$ square feet. The magnitude of effective fracture porosity in the heteroge- 
neous volcanic rocks is difficult to estimate; hence, velocities were computed using effective porosities of $0.5,10$, and 20 percent. The estimated velocities based on these values are shown in table 9 .

Thicknesses of volcanic rocks within the saturated zone are known to be greater than 11,000 feet in the western part of the caldera and greater than 6,000 feet in the eastern part. Data from hydraulic tests indicate that most ground water occurs within the upper 2,500 feet of the saturated zone, but many drill holes penetrated permeable zones at depths between 3,600 and 5,000 feet below the water table. However, many holes were not drilled to depths greater than 2,500 feet below the top of the saturated zone, so there is no control on depths to permeable intervals. Hence, a mean value of 3,500 feet is considered realistic for computation of area of underflow $(A)$.

Values for effective fracture and interstitial porosity are difficult to estimate accurately, because rocks with greatly different physical properties interfinger within the area carrying underflow. In much of the eastern part of the caldera, where rhyolitic lava flows comprise the greatest percentage of rocks in the saturated zone, the low ranges of porosity appear most valid. In this area, ground water may move almost exclusively along faults and joints; further, interconnected fractures probably total less than 10 percent of the vertical thickness of the saturated zone. Conversely, greater porosity may prevail in the rocks of much of the western part of the caldera where ash-fall and ash-flow tuffs and volcanic

TABLE 8. - Bottom-hole temperatures and thermal gradients in exploratory holes, Pahute Mesa

\begin{tabular}{|c|c|c|c|c|c|c|}
\hline \multirow[b]{2}{*}{$\begin{array}{c}\text { Exploratory } \\
\text { hole }\end{array}$} & \multirow[b]{2}{*}{$\begin{array}{l}\text { Total } \\
\text { depth } \\
(\mathrm{ft})\end{array}$} & \multicolumn{4}{|c|}{ Formation temperature } & \multirow[b]{2}{*}{$\begin{array}{c}\text { Maximum head difference } \\
\text { in exploratory hole } \\
\text { (ft) }\end{array}$} \\
\hline & & $\begin{array}{l}\text { Depth of } \\
\text { measure- } \\
\text { ment (ft) }\end{array}$ & $\begin{array}{c}\text { Date } \\
\text { logged }\end{array}$ & ${ }_{\text {(maximum) }}^{\circ}$ & $\begin{array}{l}\text { Gradient } \\
\left({ }^{\circ} \mathrm{C} \text { per }\right. \\
100 \mathrm{ft})\end{array}$ & \\
\hline$\overline{\mathrm{UE}-19 \mathrm{~b}-1 .}$ & 4,500 & 4,060 & $6-15-64$ & 34.4 & 0.53 & Stable. \\
\hline $\mathrm{UE}-19 \mathrm{c} . . .$. & 8,489 & 4,510 & $5-7-64$ & 46.6 & .75 & 41 ; decreasing with depth. \\
\hline UE-19d. & 7,689 & 6,560 & $6-25-64$ & 61.1 & .74 & 32 ; decreasing with depth. \\
\hline $\mathrm{UE}-19 e$. & 6,005 & 4,880 & $8-23-64$ & 46.6 & .69 & 21 ; decreasing with depth. \\
\hline UE-19fs.. & 6,950 & 4,400 & $8-20-65$ & 41.1 & .64 & 7 ; decreasing with depth. \\
\hline UE-19gs.. & 7,506 & 7,500 & $5-4-65$ & 61.6 & .65 & 7 ; decreasing with depth. \\
\hline UE-19h... & 3,705 & 3,456 & $7-31-65$ & 31.1 & .53 & Stable. \\
\hline UE-19i.... & 8,000 & 7,968 & $9-3-65$ & 73.8 & .77 & 40 ; increasing with depth. \\
\hline $\mathrm{PM}-1 \ldots \ldots \ldots$ & 7,858 & 7,808 & $5-1-64$ & 65.5 & .68 & Unknown. \\
\hline $\mathrm{PM}-2$. & 8,782 & 5,438 & $8-10-64$ & 83.8 & 1.31 & Increasing with depth. \\
\hline $\mathrm{U}-20 \mathrm{a}-2$. & 4,500 & 4,500 & $2-17-64$ & 41.1 & .63 & 33 ; increasing with depth. \\
\hline $\mathrm{UE}-20 \mathrm{~d} . .$. & 4,493 & 4,490 & $8-14-64$ & 46.1 & .74 & 65 ; increasing with depth. \\
\hline $\mathrm{UE}-20 \mathrm{e}-1$ & 6,395 & 6,200 & $5-27-64$ & 57.2 & .72 & 15 ; increasing with depth. \\
\hline $\mathrm{UE}-20 \mathrm{f} . . .$. & 13,686 & 12,270 & $6-25-64$ & 121.0 & .88 & 142 ; increasing with depth. \\
\hline UE-20h.... & 7,207 & 7,195 & $8-16-64$ & 50.0 & .52 & Relatively stable. \\
\hline 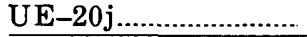 & 5,690 & 4,550 & $10-10-64$ & 46.1 & .73 & 9 ; increasing with depth. \\
\hline
\end{tabular}

${ }^{1}$ Heads decrease $28 \mathrm{ft}$ in upper $2,000 \mathrm{ft}$ of saturated zone and then increase $9 \mathrm{ft}$ to total depth.

sediments comprise the greatest percentage of the rock in the saturated zone. Total porosities of these rocks may be more than three times greater than those of rhyolitic lavas; and, in the western part, interstitial permeability may be more important in ground-water movement.

Fractures probably combine with pores to form an interconnecting system; thus, although most ground water moves through the underflow strip along fractures, two systems of permeability are involved. Hydraulic test data indicate that some ground-water movement, however small, is related to interstitial permeability. Low-permeability blocks between fractures probably result in velocities that vary as much as 2 or 3 orders of magnitude over short distances. Admittedly, any value of porosity used for computation of ground-water velocity beneath the mesa cannot be valid throughout the crosssectional area of the underflow strip. A median value of 10 percent porosity probably is the most acceptable value if credence is given to the assump- tion that most ground-water movement occurs along interconnected fractures and that some water moves through interstices.

\section{CHEMICAL QUALITY OF WATER}

Chemical analyses of water samples collected in tunnels and from springs and wells at and near the Nevada Test Site were reported by Clebsch and Barker (1960), Moore (1961), Eakin and others (1963), Schoff and Moore (1964), and in various other open-file publications of the Geological Survey. The discussion of water chemistry in this report is concerned principally with the analyses of samples collected from holes drilled at Pahute Mesa, the relation of water chemistry to the principal rocks in the volcanic sequence, and general comments on water movement inferred from water chemistry.

The principal chemical constituents in water samples from holes drilled at Pahute Mesa are listed in table 10, and selected analyses are plotted as modified pie diagrams in figure 11. Most samples repre- 
TABLE 9. - Estimated ground-water velocity in volcanic rocks beneath Pahute Mesa1

\begin{tabular}{ccccc}
\hline $\begin{array}{c}\text { Assumed effective } \\
\text { fracture and inter- } \\
\text { stitial porosity } \\
\text { (percent) }\end{array}$ & $\begin{array}{c}\text { Feet } \\
\text { per day }\end{array}$ & $\begin{array}{c}\text { Feet } \\
\text { per year }\end{array}$ & $\begin{array}{c}\text { Years } \\
\text { per mile }\end{array}$ & Remarks \\
\hline 0.5 & 0.7 & 250 & 20 & $\begin{array}{c}\text { Assumes movement only } \\
\text { through fractures. }\end{array}$ \\
10 & .04 & 15 & 350 & $\begin{array}{c}\text { Principal movement } \\
\text { through fractures } \\
\text { some interstitial } \\
\text { permeability. } \\
\text { Assumes significant } \\
\text { movement through } \\
\text { interstitial permeability. }\end{array}$ \\
\hline
\end{tabular}

${ }^{1}$ Assumes underflow of 8,000 acre-feet per year $\left(1 \times 10^{6} \mathrm{ft}^{3}\right.$ per day $)$ and underflow strip 15 miles wide and 3,500 feet thick, or $277 \times 10^{B} \mathrm{ft}^{2}$.

sent a composite of waters from various contributing zones in a single drill hole. They were collected during the final stages of pumping tests made shortly after termination of drilling operations. Pumping rates ranged from 56 to $215 \mathrm{gpm}$, and the duration of the pumping tests ranged from 12 to 48 hours. In some holes, lower contributing zones were untapped because of low pumping rates, and some samples probably contained drilling additives that could not be removed from the reservoirs during the shorter pumping periods. Despite the conditions at the time these samples were collected, the chemical data appear to represent the aquifer water. Analyses of water samples collected as above described were compared with those analyses of water samples collected from drill holes UE-19e, U-20a-2, and $\mathrm{UE}-20 \mathrm{~h}$ after these holes had been completed as supply wells and had been pumped for periods of 6 to 12 months. No major changes were found in the two sets of analyses of water samples.

In some drill holes, where differences in head potential with depth and data from radioactive-tracer surveys indicated natural crossflow, samples were collected at selected depths to determine possible variations in water quality of the major contributing zones. This survey was made approximately 2 years after the holes had been drilled to total depth and was only partially successful because caving of the walls in some boreholes prevented access of the wire-line sampling tool and because many drill holes were plugged with cement or mud or were in use as water-supply wells. Samples thus obtained are included in table 10.

Samples were collected at critical depths in drill holes UE-19d and UE-20e-1. The flow pattern in the UE-19d drill hole was essentially lateral from the top of the saturated zone to a depth of 3,400 feet below land surface; below this depth the head potential decreased, and there was downward crossflow. A radioactive-tracer survey indicated that permeable intervals below 3,400 feet were not tapped during a pumping test made in the hole. Samples were collected with the wire-line tool at depths of 3,380 and 4,200 feet. The chemical character of the samples was almost identical. The flow pattern in UE-20d was more complex. A highly permeable interval of densely welded tuff or rhyolite at a depth of approximately 3,000 feet below land surface (which had a lower head potential than those of the intervals above and below) accepted fluid from the shallower and deeper contributing zones. Samples collected at a depth of 2,920 feet in the area of downward flow and at 3,200 feet in the area of upward flow closely resemble each other chemically (table $10)$.

Testing of specific water-bearing intervals was restricted to one sample each in the UE-20e-1 and UE-19c drill holes because of impenetrable bridges in the holes. The analysis of the water sample from UE-20e-1 compared favorably with the analysis of a composite sample collected during a pumping test. There was considerable divergence, however, in the concentration of chemical constituents in the spot sample and the composite sample from the UE-19c drill hole.

Water samples of leakage or inflow from walls at the top of a chamber mined in the saturated zone in the U-19as emplacement hole were high in dissolved solids. The samples were collected under unfavorable conditions and were probably contaminated by cement and drilling additives. Chemical analyses of these samples are shown in table 10 . Because the concentration of chemical constituents is abnormally high compared with that for other samples, these data were not plotted in figure 11.

\section{RELATION OF WATER CHEMISTRY AND ROCK TYPE}

All holes drilled at the mesa were spudded and drilled to total depth in volcanic rocks. Water from the volcanic rocks at the Nevada Test Site has been classified as sodium potassium type. In this classification, sodium predominates (potassium generally is minor to negligible), and sodium and potassium together are 60 percent or more of the total cations. The water samples reported by Schoff and Moore (1964) were derived principally from contributing zones in volcanic tuff, and some water contained small amounts of calcium, magnesium, sulfate, and chloride. Water derived from drill holes at Pahute Mesa is a similar sodium potassium type. These chemical constituents comprised more than 90 percent of the total cations in more than half the water samples that were analyzed.

The chemical composition of the ground water beneath Pahute Mesa can be related to the pattern of head changes with depth (fig. 10). In the eastern part of the caldera, rhyolitic lava flows and densely welded tuffs constitute 40 to 100 percent of the vol- 


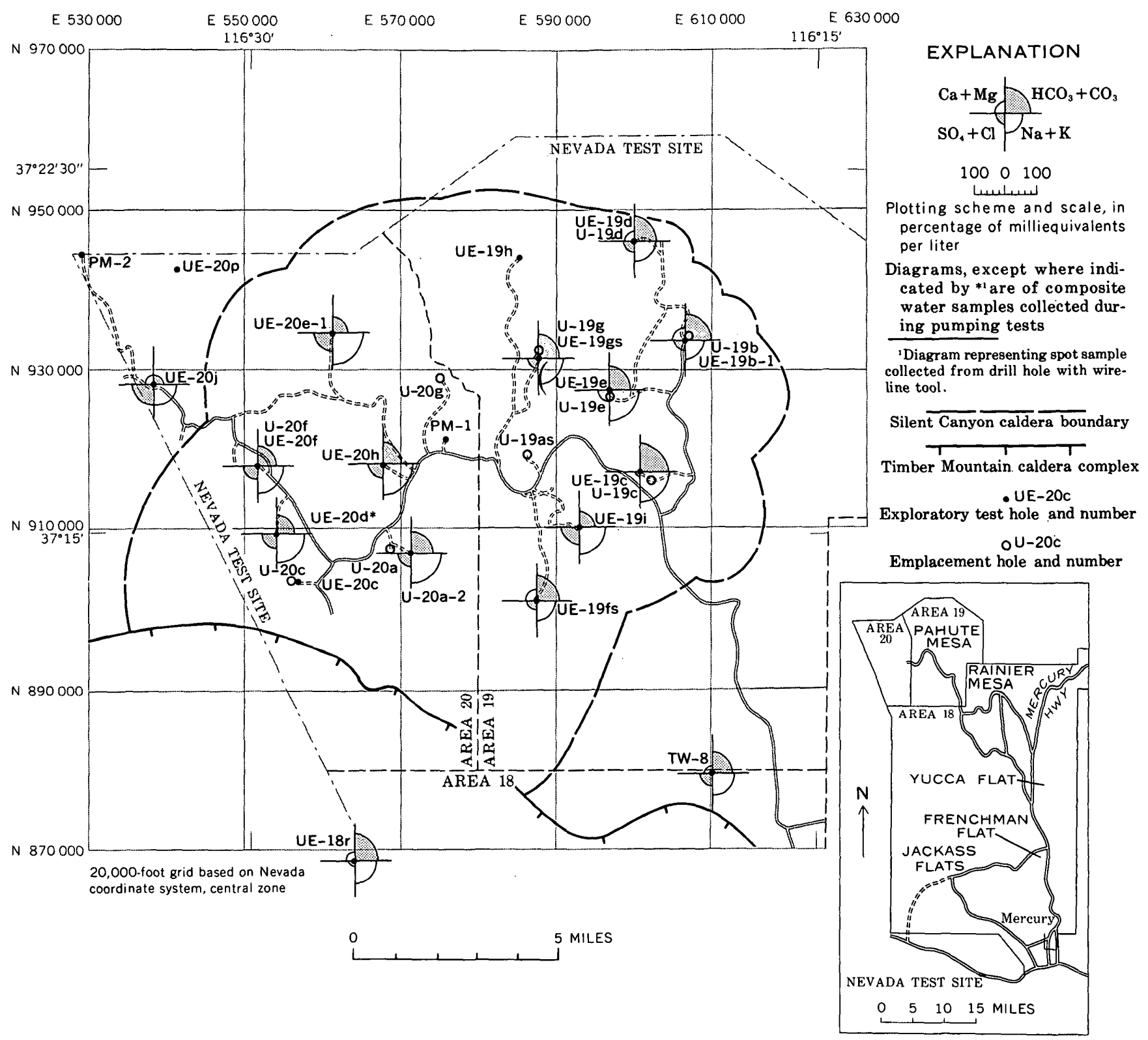

Figure 11. - Water-chemistry map.

canic rocks in the upper 2,000 feet of saturation, and head potentials decrease with depth. Water from drill holes where these conditions prevail is dominated by sodium and bicarbonate (table 11). Calcium and sulfate are abundant but accessory constituents of several of the waters.

In the western part of the caldera, zeolitized bedded ash-fall and ash-flow tuffs constitute the principal volcanic rock types in the saturated zone, and head potentials increase with depth. Water from holes drilled in these areas contains even greater relative amounts of sodium than much of the ground water in the eastern part of the caldera. (See table 11.) The diminished amounts of calcium may be due to increase in zeolitized tuffs. Among the anions, bicarbonate is the most abundant, but sulfate and chloride typically contribute greater relative amounts than in most caldera waters to the east. Bicarbonate is dominant in the southwestern part of the caldera, where rhyolitic lavas are the principal rock types in the saturated zone.

The concentrations of chemical constituents in ground water in the western part of the caldera are relatively uniform and somewhat greater than that in the eastern part; dissolved solids in water from the western part range from 206 to $336 \mathrm{mg} / \mathrm{l}$ (milligrams per liter) and average $280 \mathrm{mg} / \mathrm{l}$. In the eastern part of the caldera, dissolved solids range from 


\begin{tabular}{|c|c|c|c|c|c|c|c|c|c|c|c|c|}
\hline Hole & $\begin{array}{c}\text { Date } \\
\text { of } \\
\text { sample } \\
\text { collection }\end{array}$ & $\begin{array}{l}\text { Interval } \\
\text { sampled } \\
(\mathrm{ft})\end{array}$ & $\begin{array}{l}\text { Major } \\
\text { producing } \\
\text { zone }(\mathrm{s}) \\
(\mathrm{ft})\end{array}$ & 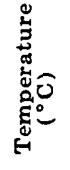 & 令 & 胥 & 㺼 & 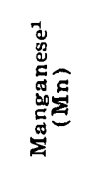 & 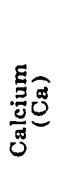 & 宽 & 吾 & हู่ \\
\hline 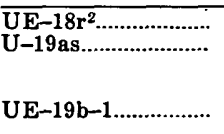 & $\begin{array}{l}1-29-68 \\
6-7-65 \\
6-7-65 \\
6-7-65 \\
6-21-64\end{array}$ & $\begin{array}{c}1,629-5,004 \\
3,195 \\
3,195 \\
3,195 \\
2,190-4,500\end{array}$ & 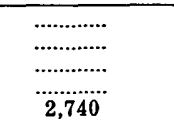 & $\begin{array}{c}32.2 \\
\ldots \ldots . \\
\ldots \ldots . \\
31.6\end{array}$ & $\begin{array}{l}45 \\
66 \\
66 \\
84 \\
47\end{array}$ & $\begin{array}{r}<0.1 \\
.04 \\
.09 \\
.08 \\
.03\end{array}$ & $\begin{array}{r}0.08 \\
.03 \\
.14 \\
.03 \\
.35\end{array}$ & $\begin{array}{l}<0.01 \\
<.02 \\
<.02 \\
<.02 \\
.05\end{array}$ & $\begin{array}{c}26 \\
2.0 \\
1.2 \\
1.6 \\
20\end{array}$ & $\begin{array}{r}1.0 \\
.1 \\
<.1 \\
<.1 \\
1.7\end{array}$ & $\begin{array}{l}0.18 \\
<.02 \\
<.02 \\
<.02 \\
\ldots \ldots .\end{array}$ & $\begin{array}{r}81 \\
200 \\
189 \\
263 \\
43\end{array}$ \\
\hline 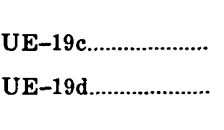 & $\begin{array}{r}10-13-64 \\
5-7-64 \\
3-9-66 \\
3-24-64 \\
6-27-64\end{array}$ & $\begin{array}{c}2,190-4,500 \\
2,421-4,520 \\
3,050 \\
724-4,500 \\
2,560-7,689\end{array}$ & $\begin{array}{c}2,740 \\
3,040-3,075 \\
3,040-3,075 \\
3,300-3,480 \\
3,300-3,480\end{array}$ & $\begin{array}{l}30.0 \\
38.3 \\
31.1 \\
32.2 \\
45.0\end{array}$ & $\begin{array}{l}41 \\
41 \\
30 \\
28 \\
58\end{array}$ & $\begin{array}{r}.04 \\
<.01 \\
<.01 \\
.03 \\
.02\end{array}$ & $\begin{array}{l}.41 \\
.04 \\
.04 \\
.59 \\
.06\end{array}$ & $\begin{array}{r}1.2 \\
.01 \\
.90 \\
.03 \\
<.01\end{array}$ & $\begin{array}{l}24 \\
1.0 \\
13 \\
29 \\
44\end{array}$ & $\begin{array}{r}2.4 \\
.1 \\
.1 \\
2.9 \\
5.0\end{array}$ & $\begin{array}{l}.05 \\
.09 \\
.29 \\
. . .\end{array}$ & $\begin{array}{r}42 \\
29 \\
141 \\
173 \\
150\end{array}$ \\
\hline UE-19e............................. & $\begin{array}{l}6-27-64 \\
3-9-66 \\
3-9-66 \\
4-22-65\end{array}$ & $\begin{array}{c}2,560-7,689 \\
3,380 \\
4,200 \\
2,475-6,005\end{array}$ & $\begin{array}{c}3,300-3,480 \\
3,300-3,480 \\
3,300-3,480 \\
2,650-2,690 ; \\
4,970-4,990 \\
2,650-2,690 ; \\
4,970-4,990\end{array}$ & $\begin{array}{r}45.0 \\
34.4 \\
34.4 \\
\cdots \cdots\end{array}$ & $\begin{array}{l}49 \\
55 \\
\mathbf{5 5} \\
\mathbf{5 0}\end{array}$ & $\begin{array}{r}.05 \\
<.01 \\
<.01 \\
.52\end{array}$ & $\begin{array}{r}.06 \\
<.01 \\
.02 \\
.09\end{array}$ & $\begin{array}{r}<.01 \\
.58 \\
.56 \\
.02\end{array}$ & $\begin{array}{l}29 \\
58 \\
57 \\
\quad .5\end{array}$ & $\begin{array}{l}1.4 \\
2.8 \\
2.8 \\
<.1\end{array}$ & $\begin{array}{l}. \ldots . . \\
.19 \\
.19 \\
\cdots \ldots . .\end{array}$ & $\begin{array}{r}148 \\
153 \\
153 \\
50\end{array}$ \\
\hline \multirow[t]{2}{*}{ 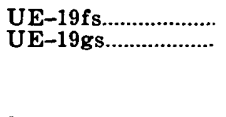 } & $\begin{array}{l}8-18-65 \\
3-27-65\end{array}$ & $\begin{array}{l}2,565-4,779 \\
2,650-4,508\end{array}$ & \multirow{3}{*}{$\begin{array}{c}2,940 ; 3,970 \\
4,270 \\
2,940 ; 3,970 \\
4,270 \\
3,460-3,618 \\
\ldots \ldots \ldots . .\end{array}$} & $\begin{array}{l}37.7 \\
41.6\end{array}$ & $\begin{array}{l}56 \\
46\end{array}$ & $\begin{array}{l}.02 \\
.04\end{array}$ & $\begin{array}{r}<.01 \\
.07\end{array}$ & $\begin{array}{l}.03 \\
.01\end{array}$ & $\begin{array}{l}11 \\
12\end{array}$ & $\begin{array}{l}1.6 \\
<.1\end{array}$ & $\begin{array}{l}.02 \\
. \cdots . .\end{array}$ & $\begin{array}{l}29 \\
68\end{array}$ \\
\hline & $8-2-66$ & $2,650-7,500$ & & 41.6 & 50 & .01 & $<.01$ & .01 & 2.8 & $<.1$ & .02 & 84 \\
\hline 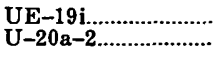 & $\begin{array}{r}9-2-65 \\
10-14-64\end{array}$ & $\begin{array}{l}2,896-8,000 \\
2,066-4,500\end{array}$ & & $\begin{array}{l}47.2 \\
26.6\end{array}$ & $\begin{array}{l}39 \\
41\end{array}$ & $\begin{array}{l}.08 \\
.05\end{array}$ & $\begin{array}{r}<.01 \\
.13\end{array}$ & $<.05$ & $\begin{array}{l}5.0 \\
5.9\end{array}$ & $<.1$ & $\begin{array}{c}.04 \\
\cdots \cdots\end{array}$ & $\begin{array}{l}75 \\
58\end{array}$ \\
\hline \multirow[t]{5}{*}{ 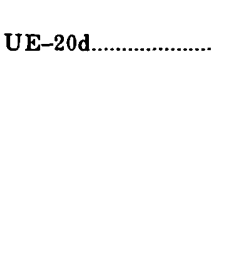 } & $\begin{array}{l}3-10-66 \\
3-8-66\end{array}$ & $\begin{array}{c}2,066-4,500 \\
2,920\end{array}$ & \multirow{4}{*}{$\begin{array}{r}2,570-2,720 ; \\
4,250-4,460 \\
2,570-2,720 ; \\
4,250-4,460 \\
2,570-2,720 ; \\
4,250-4,460 \\
2,570-2,720 ; \\
4,250-4,460\end{array}$} & ….. & $\begin{array}{l}48 \\
37\end{array}$ & $\begin{array}{l}<.01 \\
<.01\end{array}$ & $\begin{array}{l}.09 \\
.05\end{array}$ & $\begin{array}{l}.01 \\
.01\end{array}$ & $\begin{array}{l}6.1 \\
1.4\end{array}$ & $<.1$ & $\begin{array}{l}.03 \\
.03\end{array}$ & $\begin{array}{l}55 \\
81\end{array}$ \\
\hline & $3-8-66$ & 3,200 & & 41.6 & 46 & .04 & .07 & .01 & 1.4 & $<.1$ & .03 & 83 \\
\hline & $7-27-66$ & $2,446-4,500$ & & 40.0 & 47 & $<.01$ & $<.01$ & $<.01$ & 4.3 & .1 & .07 & 88 \\
\hline & $7-28-66$ & $2,446-4,500$ & & 40.0 & 52 & $<.01$ & $<.01$ & .02 & 21 & .1 & .13 & 68 \\
\hline & $8-12-66$ & $2,446-4,500$ & \multirow{2}{*}{$\begin{array}{c}2,570-2,720: \\
4,250-4,460 \\
3,550-3,660 \\
3,550-3,660 \\
4,570-4,680 \\
4,030\end{array}$} & \multirow[b]{2}{*}{$\begin{array}{l}47.2 \\
32.8 \\
48.8 \\
41.1\end{array}$} & 45 & .09 & $<.01$ & .39 & 8.5 & .1 & $<.01$ & 107 \\
\hline 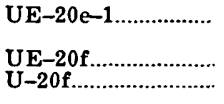 & $\begin{array}{l}6-5-64 \\
3-8-66 \\
8-11-64 \\
3-28-66\end{array}$ & $\begin{array}{c}1,825-6,395 \\
2,600 \\
4,456-13,686 \\
4,026\end{array}$ & & & $\begin{array}{l}44 \\
36 \\
47 \\
36\end{array}$ & $\begin{array}{l}.82 \\
.01 \\
.07 \\
.04\end{array}$ & $\begin{array}{r}.13 \\
.02 \\
.56 \\
<.01\end{array}$ & $\begin{array}{r}<.01 \\
<.01 \\
.14 \\
.01\end{array}$ & $\begin{array}{r}.4 \\
.2 \\
4.8 \\
.8\end{array}$ & $\begin{array}{l}<.1 \\
<.1 \\
.1\end{array}$ & $\begin{array}{r}.03 \\
<\ldots \ldots \\
<.01\end{array}$ & $\begin{array}{r}112 \\
83 \\
113 \\
69\end{array}$ \\
\hline TW-8 $8^{2} \ldots \ldots \ldots \ldots$ & $10-15-64$ & $1,068-1,860$ & $\begin{array}{c}4,025 \\
4,000-4,070 \\
2,050-2,250 \\
2,960-3,830 \\
1,300-1,780 \\
\end{array}$ & 26.1 & 45 & $<.01$ & $<.01$ & $\leq .01$ & 8.8 & .9 & $\ldots \ldots$. & 30 \\
\hline
\end{tabular}

${ }^{1}$ In solution at time of analysis or collection.

117 to $248 \mathrm{mg} / \mathrm{l}$ and average $200 \mathrm{mg} / \mathrm{l}$. Water from UE-19d contains $550 \mathrm{mg} / \mathrm{l}$ dissolved solids, very high for the area, and is not included in the ranges and averages just given. The generally smaller amounts of dissolved solids in water in the eastern part of the caldera may indicate a relatively short contact time with the rocks, or nearness to areas of recharge. Indeed, the mineralization in water from some of the drill holes is similar to that of the perched water collected during tunnel mining beneath Rainier Mesa (Clebsch and Barker, 1960). Recharge from precipitation is greatest in the east, where altitudes are greatest; however, most water probably enters the report area as underflow from valleys to the northeast and north.

Water from drill hole UE-20j, west of the caldera boundary, is rich in sodium and has nearly equal amounts of calcium plus magnesium, bicarbonate, sulfate, and chloride (table 11). The higher-thannormal sulfate content may be due to extensive hydrothermal alteration in older volcanic rocks penetrated in the drill hole. The drill hole is approximately 3.5 miles southeast of, and down gradient from, the PM-2 drill hole, in which a granitic intrusive body was penetrated at a depth of 8,380 feet. Altered dacite in the intrusive contact zone consists of microcrystalline aggregates of chlorite, sericite, quartz, calcite, and pyrite. Dacitic lava flows and flow breccias penetrated at depths from 2,870 to 8,270 feet in PM-2 are pyritized and calcitized.

Water collected from test well TW-8, south of the eastern part of the caldera, and water from the UE-18r drill hole, south of the western part of the caldera in the moat area of the Timber Mountain caldera, are of the sodium bicarbonate type but contain a significant quantity of calcium plus magne- 


\begin{tabular}{|c|c|c|c|c|c|c|c|c|c|c|c|c|c|c|}
\hline \multirow[b]{2}{*}{ 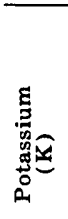 } & \multirow[b]{2}{*}{ 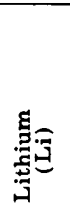 } & \multirow[b]{2}{*}{ 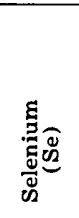 } & \multirow[b]{2}{*}{ 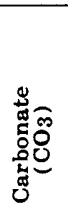 } & \multirow[b]{2}{*}{ 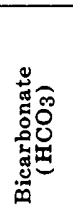 } & \multirow[b]{2}{*}{ 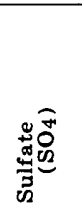 } & \multirow[b]{2}{*}{ 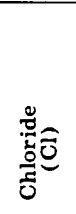 } & \multirow[b]{2}{*}{ 总国 } & \multirow[b]{2}{*}{ 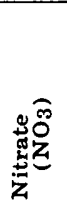 } & \multirow[b]{2}{*}{ 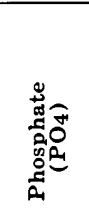 } & \multicolumn{3}{|c|}{ Hardness as CaCO } & \multirow[b]{2}{*}{ 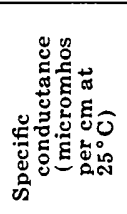 } & \multirow[b]{2}{*}{ 垔 } \\
\hline & & & & & & & & & & 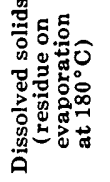 & 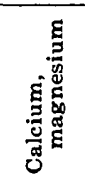 & 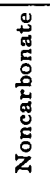 & & \\
\hline $\begin{array}{l}3.1 \\
5.5 \\
5.8 \\
7.1 \\
2.9\end{array}$ & $\begin{array}{r}0.10 \\
.61 \\
.62 \\
.85 \\
. \ldots . .\end{array}$ & $\begin{array}{r}0.11 \\
.06 \\
.07 \\
.04 \\
.03\end{array}$ & $\begin{array}{r}0 \\
39 \\
8 \\
82 \\
0\end{array}$ & $\begin{array}{l}252 \\
174 \\
205 \\
261 \\
130\end{array}$ & $\begin{array}{l}24 \\
26 \\
27 \\
51 \\
24\end{array}$ & $\begin{array}{l}7.8 \\
19 \\
11 \\
12 \\
13\end{array}$ & $\begin{array}{c}2.9 \\
80 \\
80 \\
70 \\
3.2\end{array}$ & $\begin{array}{r}0.6 \\
1.0 \\
2.5 \\
12.1 \\
.1\end{array}$ & $\begin{array}{l}<0.01 \\
<.01 \\
<.01 \\
<.01 \\
<.01\end{array}$ & $\begin{array}{l}313 \\
526 \\
491 \\
723 \\
242\end{array}$ & $\begin{array}{r}69 \\
6 \\
3 \\
4 \\
57\end{array}$ & $\begin{array}{l}0 \\
0 \\
0 \\
0 \\
0\end{array}$ & $\begin{array}{r}449 \\
889 \\
828 \\
1,150 \\
316\end{array}$ & $\begin{array}{l}8.0 \\
9.3 \\
8.4 \\
9.3 \\
6.7\end{array}$ \\
\hline $\begin{array}{r}3.0 \\
<.1 \\
.2 \\
3.6 \\
3.7\end{array}$ & $\begin{array}{r}.04 \\
.28 \\
.30 \\
. \ldots . .\end{array}$ & $\begin{array}{c}.03 \\
.05 \\
.04 \\
.04 \\
. \cdots . . .\end{array}$ & $\begin{array}{l}0 \\
0 \\
0 \\
0 \\
0\end{array}$ & $\begin{array}{r}150 \\
66 \\
400 \\
424 \\
380\end{array}$ & $\begin{array}{l}21 \\
4.6 \\
<.1 \\
63 \\
80\end{array}$ & $\begin{array}{c}6.8 \\
2.6 \\
7.7 \\
39 \\
33\end{array}$ & $\begin{array}{l}3.2 \\
1.2 \\
4.3 \\
4.4 \\
6.9\end{array}$ & $\begin{array}{r}.4 \\
1.8 \\
.2 \\
30.0 \\
.1\end{array}$ & $\begin{array}{l}<.01 \\
<.01 \\
<.01 \\
<.01 \\
<.01\end{array}$ & $\begin{array}{l}229 \\
117 \\
390 \\
560 \\
572\end{array}$ & $\begin{array}{r}70 \\
3 \\
33 \\
85 \\
131\end{array}$ & $\begin{array}{l}0 \\
0 \\
0 \\
0 \\
0\end{array}$ & $\begin{array}{l}314 \\
124 \\
644 \\
889 \\
851\end{array}$ & $\begin{array}{l}7.4 \\
7.6 \\
7.9 \\
7.5 \\
7.9\end{array}$ \\
\hline $\begin{array}{l}4.0 \\
3.7 \\
4.3 \\
1.2\end{array}$ & $\begin{array}{l}.38 \\
.38 \\
.15\end{array}$ & \begin{tabular}{c}
$\ldots . . .$. \\
$\cdots \cdots .$. \\
\hdashline$\cdots .$. \\
$\cdots \cdots .$.
\end{tabular} & $\begin{array}{l}0 \\
0 \\
0 \\
0\end{array}$ & $\begin{array}{r}320 \\
481 \\
489 \\
86\end{array}$ & $\begin{array}{l}66 \\
60 \\
57 \\
20\end{array}$ & $\begin{array}{l}30 \\
19 \\
20 \\
11\end{array}$ & $\begin{array}{l}7.5 \\
5.0 \\
4.9 \\
1.2\end{array}$ & $\begin{array}{r}<.1 \\
.5 \\
.6 \\
3.4\end{array}$ & $\begin{array}{l}<.01 \\
<.01 \\
.01\end{array}$ & $\begin{array}{l}525 \\
581 \\
578 \\
190\end{array}$ & $\begin{array}{r}79 \\
156 \\
154 \\
1\end{array}$ & $\begin{array}{l}0 \\
0 \\
0 \\
0\end{array}$ & $\begin{array}{l}777 \\
911 \\
906 \\
232\end{array}$ & $\begin{array}{l}7.6 \\
7.9 \\
7.9 \\
7.4\end{array}$ \\
\hline .8 & .06 & .01 & 0 & 80 & 16 & 3.7 & 5.3 & 1.7 & $<.01$ & 169 & 9 & 0 & 204 & 8.2 \\
\hline $\begin{array}{r}3.0 \\
.6\end{array}$ & $\begin{array}{l}.02 \\
. \ldots . . .\end{array}$ & $\ldots$ & $\begin{array}{l}0 \\
0\end{array}$ & $\begin{array}{r}86 \\
146\end{array}$ & 36.0 & $\begin{array}{l}6.3 \\
9.0\end{array}$ & $\begin{array}{l}3.6 \\
2.0\end{array}$ & $\begin{array}{l}2.2 \\
1.3\end{array}$ & $<.01$ & $\begin{array}{l}186 \\
248\end{array}$ & $\begin{array}{l}34 \\
30\end{array}$ & $\begin{array}{l}0 \\
0\end{array}$ & $\begin{array}{l}202 \\
345\end{array}$ & $\begin{array}{l}8.1 \\
8.2\end{array}$ \\
\hline 1.5 & .04 & .01 & 0 & 123 & 43 & 22 & 3.0 & .6 & $<.01$ & 270 & 7 & 0 & 388 & 8.2 \\
\hline $\begin{array}{r}.5 \\
1.9\end{array}$ & $\begin{array}{l}.05 \\
. \ldots . . .\end{array}$ & .01 & $\begin{array}{l}0 \\
0\end{array}$ & $\begin{array}{r}98 \\
108\end{array}$ & $\begin{array}{l}70 \\
28\end{array}$ & $1^{7.0}$ & $\begin{array}{l}5.5 \\
2.6\end{array}$ & $\begin{array}{r}.2 \\
1.2\end{array}$ & $<.01$ & $\begin{array}{l}230 \\
206\end{array}$ & $\begin{array}{l}13 \\
15\end{array}$ & $\begin{array}{l}0 \\
0\end{array}$ & $\begin{array}{l}228 \\
285\end{array}$ & $\begin{array}{l}7.7 \\
6.9\end{array}$ \\
\hline .2 & $\begin{array}{l}.06 \\
.08\end{array}$ & $\ldots$ & $\begin{array}{l}0 \\
0\end{array}$ & $\begin{array}{l}106 \\
122\end{array}$ & $\begin{array}{l}27 \\
40\end{array}$ & $\begin{array}{l}11 \\
23\end{array}$ & $\begin{array}{l}2.7 \\
3.1\end{array}$ & $\begin{array}{l}1.4 \\
1.3\end{array}$ & $<.01$ & $\begin{array}{l}201 \\
252\end{array}$ & $\begin{array}{r}16 \\
4\end{array}$ & $\begin{array}{l}0 \\
0\end{array}$ & $\begin{array}{l}286 \\
384\end{array}$ & $\begin{array}{l}7.7 \\
8.2\end{array}$ \\
\hline .1 & .08 & ....... & 0 & 120 & 42 & 24 & 3.1 & 1.7 & $<.01$ & 282 & 4 & 0 & 351 & 8.3 \\
\hline 1.7 & .00 & .01 & 0 & 137 & 44 & 23 & 2.8 & $<.1$ & $<.01$ & 286 & 11 & 0 & 405 & 7.8 \\
\hline .5 & .00 & .01 & 5 & 143 & 53 & 8.8 & 2.4 & .3 & $<.01$ & 281 & 53 & 0 & 394 & 8.4 \\
\hline 2.6 & .08 & .01 & 4 & 192 & 40 & 24 & 3.0 & $<.1$ & $<.01$ & 327 & 22 & 0 & 487 & 8.5 \\
\hline $\begin{array}{r}3.8 \\
2.0 \\
2.0 \\
.6\end{array}$ & $\begin{array}{c}7.07 \\
.07 \\
.02\end{array}$ & \begin{tabular}{c}
$\ldots . .$. \\
$\cdots \cdots .$. \\
\hdashline .01 \\
.01
\end{tabular} & $\begin{array}{r}0 \\
2 \\
0 \\
10\end{array}$ & $\begin{array}{l}130 \\
119 \\
164 \\
103\end{array}$ & $\begin{array}{l}43 \\
42 \\
48 \\
30\end{array}$ & $\begin{array}{c}57 \\
20 \\
40 \\
6.6\end{array}$ & $\begin{array}{l}4.6 \\
4.5 \\
5.0 \\
3.9\end{array}$ & $\begin{array}{r}1.0 \\
.5 \\
.1 \\
<.1\end{array}$ & $\begin{array}{r}<.01 \\
<.01 \\
.02 \\
.07\end{array}$ & $\begin{array}{l}336 \\
245 \\
368 \\
240\end{array}$ & $\begin{array}{r}1 \\
1 \\
12 \\
3\end{array}$ & $\begin{array}{l}0 \\
0 \\
0 \\
0\end{array}$ & $\begin{array}{l}515 \\
352 \\
519 \\
298\end{array}$ & $\begin{array}{l}7.7 \\
8.5 \\
7.2 \\
8.9\end{array}$ \\
\hline $\begin{array}{r}.8 \\
1.8 \\
6.4\end{array}$ & $\begin{array}{l}.00 \\
.08 \\
. \cdots . .\end{array}$ & 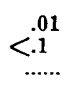 & $\begin{array}{r}14 \\
0 \\
0\end{array}$ & $\begin{array}{r}98 \\
107 \\
150\end{array}$ & $\begin{array}{r}23 \\
30 \\
135\end{array}$ & $\begin{array}{c}7.0 \\
15 \\
115\end{array}$ & $\begin{array}{l}3.7 \\
2.7 \\
2.2\end{array}$ & $\begin{array}{r}.7 \\
1.3 \\
.9\end{array}$ & $\begin{array}{l}.12 \\
<.01 \\
<.01\end{array}$ & $\begin{array}{l}194 \\
231 \\
583\end{array}$ & $\begin{array}{r}1 \\
2 \\
120\end{array}$ & $\begin{array}{l}0 \\
0 \\
0\end{array}$ & $\begin{array}{l}297 \\
301 \\
904\end{array}$ & $\begin{array}{l}9.1 \\
8.1 \\
7.0\end{array}$ \\
\hline 3.3 & $\ldots \ldots$. & $\ldots . .$. & 0 & 78 & 16 & 7.8 & .7 & 3.6 & .01 & 149 & 26 & 0 & 197 & 6.8 \\
\hline
\end{tabular}

TABLE 11. - Relative abundance of principal ions in selected ground-water samples from Pahute Mesa

[On the basis of milliequivalents per liter]

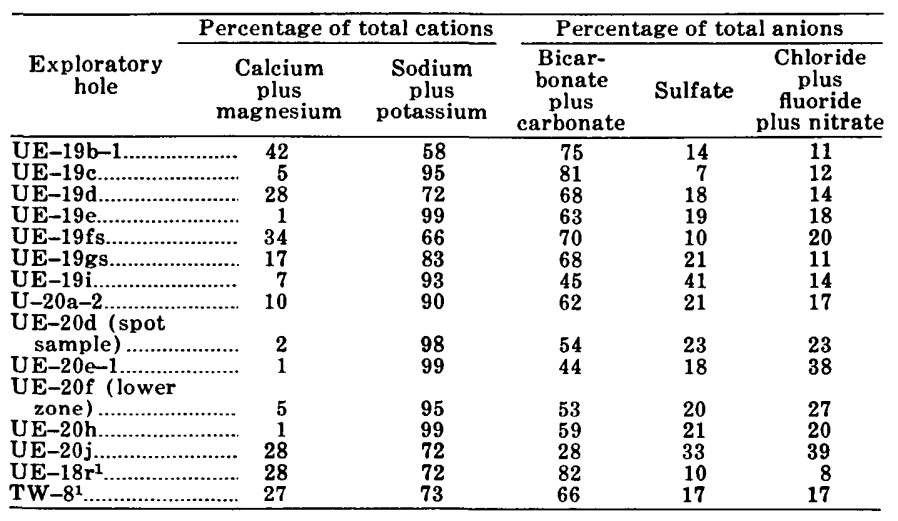

ISouth of Pahute Mesa.

sium, sulfate, and chloride ions. Mineralization is greater in UE-18r than in TW-8, but the chemical constituents of both waters are similar.

\section{WATER CHEMISTRY AND REGIONAL MOVEMENT OF GROUND WATER}

Chemical data for water samples collected from wells and springs at Oasis Valley, western Jackass Flats, and north-central Amargosa Desert corroborate the direction of ground-water movement. The water from springs and wells in Oasis Valley is of the sodium bicarbonate type, similar to the water beneath Pahute Mesa. Amounts of sulfate and chloride are similar to those in waters beneath the western part of the caldera and are similarly subordinate to bicarbonate. Dissolved-solids content of water from Oasis Valley is greater than that of water beneath Pahute Mesa.

\section{ENGINEERING HYDROLOGY}

Underground testing of nuclear devices at Pahute Mesa involves emplacement of devices far below the top of the saturated zone, commonly in mined chambers at the emplacement depth. During excavation 
of the chambers and preparations for detonation of the nuclear device, only a small influx of water can be tolerated. A variety of hydraulic tests has been made to determine the water-yielding potential of the strata penetrated by each exploratory hole and, in particular, of those strata with the lowest water yield or those most favorable for development of chambers.

Five chambers, of different dimensions, have been mined successfully at depths as much as 2,600 feet below the top of the saturated zone (table 12). At each site an emplacement hole, usually 72 inches in diameter, was drilled near the exploratory hole. Drilling of the emplacement hole was interrupted several hundred feet above the interval proposed for mining. Casing with an outer diameter of $103 / 4$ inches was tack-cemented, and a 97/8-inch hole was drilled and cored through the critical interval to permit geophysical logging and hydraulic testing. The exact intervals for mining were based on these geologic and hydraulic-testing data. Emplacement holes were drilled to desired depths, and 48-inch casings were cemented in place.

Pumpage from exploratory holes has been the principal water supply for construction and drilling at Pahute Mesa. The greatest water yields generally were obtained from holes drilled in areas where fractured rhyolitic lava flows and densely welded tuffs predominate in the saturated zone. A permanent water supply could be developed from wells in areas away from probable damage from nuclear events and in areas where these rocks predominate.

\section{ROCK MEDIA BEST SUITED FOR CHAMBER} CONSTRUCTION

Ash-fall and nonwelded ash-flow tuff which have been zeolitized or argillized are hydrologically the most desirable rocks for chamber construction. Although interstitial porosity and permeability of these rocks are greater than those of the rhyolitic lavas and densely welded tuffs, fractures reseal more readily in these relatively incompetent rocks. Hence, fracture permeability generally is much lower in ash-fall and nonwelded tuffs than that of the rhyolitic lavas and densely welded tuffs. The yield of water to wells from ash-fall and nonwelded ash-flow tuffs is low.

Intervals of 200 feet of ash-fall and nonwelded ash-flow tuff in exploratory holes having relative specific capacities less than $0.03 \mathrm{gpm}$ per foot of drawdown are considered most favorable for chamber construction. Those intervals having relative specific capacities ranging from 0.03 and $0.04 \mathrm{gpm}$ per foot of drawdown are considered marginal, and those having greater than 0.04 should be mined only where the head is small. Rhyolite and densely welded tuff are not considered favorable rock types for mining chambers. Although these indurated rocks may be impermeable immediately adjacent to the borehole, open water-bearing fractures a short distance from the borehole might be encountered during mining.

\section{WATER INFLOW TO CHAMBERS}

Early estimates of inflow to chambers were made to establish hydrologic safety limits for miners. One method was developed by W. E. Hale (written commun., 1964). For this method, permeability was derived, approximately, from values of relative specific capacity. Estimates of inflow were graphed for two sizes of chambers, $50 \times 10 \times 10$ feet and $20 \times 10 \times 10$ feet, and for heads of water from 0 to 3,000 feet. Inflow, plotted from these graphs, proved highly conservative, based on actual measurements during mining operations.

Presently, hydraulic-test data are used to compute the transmissivity and storage coefficient of the tested interval using a method of analyzing slug tests by type curves developed by Cooper, Bredehoeft, and Papadopulos (1967). Utilizing these data, Dudley (1970) developed a technique to compute the gradually declining discharge at constant drawdown to a large-diameter opening in the interior of an aquitard, which is bounded above and below by recharge boundaries. By treating the chamber as a large-diameter well pumped at constant drawdown, the nonsteady discharge can be computed by the method of Hantush (1961) for analyzing flowing wells under leaky artesian conditions. For this technique, the assumption is made of the instantaneous appearance of a full-sized chamber. Obviously, this assumption is not met. Hence, the calculated inflow during early stages will be higher than that actually found. Since the gradual construction of the chamber retards early inflow, the dissipation of hydraulic head is also retarded, and the inflow calculated for later times will be less than the actual inflow. For safety reasons, pumping systems should be designed to handle the maximum potential inflow.

Hydrologic and construction data for the chambers mined at Pahute Mesa are shown in table 12. Prior to each of the mining operations, a series of radiating small-diameter holes was drilled through ports in the 48-inch casing into the prospective chamber zones. These holes usually were 1.5 inches in diameter and about 25 feet long and were sloped about $35^{\circ}$ downward from horizontal. Measurements of water inflow from these holes into the casing showed a significant decrease with time. A 30 - to $40-$ percent decline of inflow occurred during the first 
TABLE 12. - Water-inflow, construction, and hydraulic-testing data for mined emplacement chambers within the saturated zone, Pahute Mesa

\begin{tabular}{|c|c|c|c|c|c|c|c|}
\hline \multirow{2}{*}{$\begin{array}{c}\text { Exploratory } \\
\text { hole }\end{array}$} & \multirow{2}{*}{$\begin{array}{l}\text { Depth to } \\
\text { chamber center } \\
(\mathrm{ft})^{1}\end{array}$} & \multirow{2}{*}{$\begin{array}{l}\text { Depth to } \\
\text { water } \\
\text { (ft) }\end{array}$} & \multicolumn{2}{|c|}{ Chamber size (ft) } & \multicolumn{2}{|c|}{$\begin{array}{l}\text { Hydraulic-testing data for } \\
\text { chamber zone }\end{array}$} & \multirow{2}{*}{$\begin{array}{l}\text { Inflow } \\
(\mathrm{gph})^{2}\end{array}$} \\
\hline & & & Diameter & Height & $\begin{array}{l}\text { Relative specific } \\
\text { capacity (gpm per } \\
\text { foot of drawdown) }\end{array}$ & $\begin{array}{l}\text { Thickness of } \\
\text { straddle packed } \\
\text { interval (ft) }\end{array}$ & \\
\hline U-19as........................ & 3,100 & 2,192 & 14 & 35 & 0.003 & 198 & 10 \\
\hline 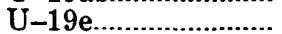 & 4,765 & 2,240 & 24 & 46 & .0005 & 68 & ${ }^{3} 110$ \\
\hline $\mathrm{U}-19 \mathrm{~g}$ & 3,010 & 2,058 & 26 & 42 & .03 & 118 & 224 \\
\hline $\mathrm{U}-20 \mathrm{c}$. & 4,600 & 2,097 & 24 & 31 & .002 & 58 & ${ }^{3} 214$ \\
\hline 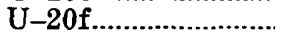 & 4,040 & 1,930 & 16 & 35 & .01 & 198 & 70 \\
\hline
\end{tabular}

1All depths are referred to land surface.

2Virtually stable values, in gallons per hour, after 1-3 months of continuous inflow. casing.

Inflow to these chambers was anomalously high because of some vertical leakage through annular cement around 48-in.

few days (fig. 12). The decline after 1 week was slight. These small-diameter holes were used for pressure grouting in attempts to seal any waterbearing fractures before mining. The benefits of the pressure-grouting operations were questionable. Nevertheless, water inflow during mining operations presented no serious problems.

Inflow rates to the chambers, 1 to 3 months after completion of mining operations and when inflow was virtually stable, were obtained from pumpage data (table 12). The greatest volume of inflow, 224 gph (gallons per hour) was measured in U-19g. Hydraulic-testing data indicated that the relative specific capacity of the interval mined in this hole was $0.03 \mathrm{gpm}$ per foot of drawdown. Intervals mined in the other emplacement holes had relative specific capacities no greater than 0.01 .

Zones 150 to 200 feet thick which were tested in vertical exploratory holes had relative specific capacities ranging from less than 0.001 to $0.78 \mathrm{gpm}$ per foot of drawdown. An interval having a relative specific capacity less than $0.03 \mathrm{gpm}$ per foot of drawdown is considered safe from a hydrologic standpoint for mining at depths as great as 3,000 feet below static water level. An interval having a relative specific capacity of 0.03 to $0.04 \mathrm{gpm}$ per foot of drawdown is considered of marginal safety for chamber construction under most hydraulic heads anticipated for Pahute Mesa chambers. And an interval having a relative specific capacity greater than $0.04 \mathrm{gpm}$ per foot of drawdown should be mined only where the head is small.

\section{WATER SUPPLY}

Exploratory drill holes at Pahute Mesa are used on a temporary basis to supply water for drilling and construction operations. These drill holes eventually are plugged with cement or instrumented for nuclear events scheduled in nearby emplacement holes. The few drill holes not directly related to nuclear testing are virtually water-tight and nonproductive or are located where they will probably be destroyed by future nuclear events. To assure a permanent supply of water from wells (those not likely to be disrupted by a nuclear detonation), the wells must be drilled at distances at least three times the total depths of the emplacement holes away from all emplacement holes. Within the areas that are available, selection of well sites should be based on rock types in the saturated zone, proximity to faults, and accessibility.

As an alternative to drilling supply wells on Pahute Mesa, construction water could be piped or hauled from test well $\mathrm{TW}-8$, an existing supply well off the mesa, or from UE-18r, drilled in the moat area of the Timber Mountain caldera complex. Whether piping or hauling water would be more feasible than drilling new supply wells on the mesa is principally a matter of comparative costs-an economic question is beyond the scope of this report.

\section{AREAS FAVORABLE FOR DRILLING WATER-SUPPLY WELLS}

Pumping tests were made in 14 exploratory holes at Pahute Mesa. The greatest water yields generally were obtained from holes drilled in areas where the more competent rocks, fractured rhyolitic lava flows and densely welded tuffs, predominate in the upper 2,000 feet of the saturated zone. Resistivity curves on electric logs made in holes drilled at the mesa are useful for defining the competency of rocks; apparent resistivities of densely welded tuff, vitrophyres, and rhyolitic lavas generally exceed $225 \mathrm{ohm}$-meters. Figure 3, a contour map based on the percentage of rocks with resistivities greater than $225 \mathrm{ohm}$-meters in the upper 2,000 feet of the saturated zone, can be used to locate favorable areas for wells. A well drilled 2,000 feet into the saturated zone within the contour intervals in which high-resistivity rocks comprise 40 to 100 percent of the rock section should penetrate an adequate thickness of favorable rocks and produce a satisfactory supply of water.

Holes drilled in areas of major faults-principally near boundary faults of the Silent Canyon caldera (pl. 1) - may have high water yields even though less favorable rocks occur in the saturated zone. In 


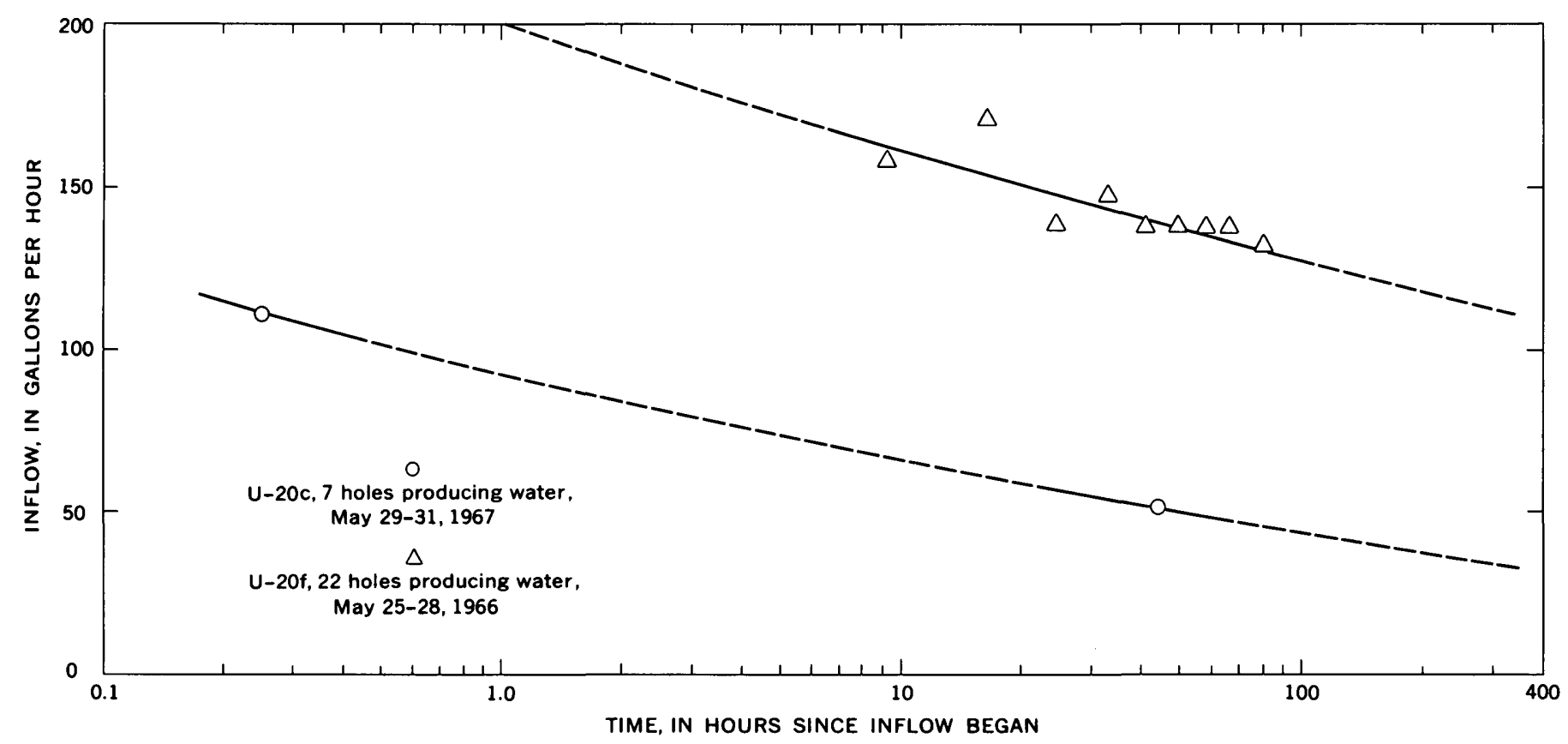

Figure 12. - Inflow through small-diameter holes drilled into prospective chamber zones U-20f and U-20c.

exploratory hole UE-20j, west of the caldera boundary fault, bedded and welded tuffs of the Belted Range Tuff are permeable. Cores from that hole show that the permeability is associated with faults. The Belted Range Tuff is relatively impermeable where it is not highly faulted.

\section{SUMMARY AND CONCLUSIONS}

The Silent Canyon caldera, beneath the eastern part of Pahute Mesa, is elliptical in plan, measuring approximately 11 by 14 miles. The greater axis trends in a north-northeast direction, roughly parallel to the strike of basin-and-range faults. It is asymmetrical in cross section; the amount of collapse in the ring-fracture zone ranges from about 7,000 feet on the west side to about 5,000 feet on the northeast side. A north-trending structural high separates two distinct intrabasin deeps within the caldera.

Pre-Tertiary rocks were not penetrated in exploratory holes drilled within the caldera or in the immediate vicinity outside the caldera. The rocks that afford positive stratigraphic control on the surface and in the subsurface at Pahute Mesa are the widespread ash-flow tuffs, which are probably contemporaneous with initial caldera collapse, and the major ash-flows, which are postcaldera in age. Heterogeneous intracaldera rocks occur between these widespread ash-flow sheets in the saturated zone under Pahute Mesa. These intracaldera rocks include ash-fall and ash-flow tuffs, and rhyolitic lava flows which emanated from fissures within the subsiding caldera and from nearby volcanic centers. The variable vertical and horizontal distribution of these rocks over short distances makes subsurface correlations between test holes extremely difficult.

Although interstitial permeability of the volcanic rocks is small, it does allow for some ground-water movement; most ground water moves along the hydraulic gradient in fractures. Rhyolitic lavas are relatively competent rocks; hence, compressibility of these rocks is moderate, and faults and joints may remain open even at great depths. Most of the cores of rhyolitic lava flows recovered from drill holes contain some fractures; however, not all the intervals that are fractured are permeable. In the intervals of low permeability, the fractures apparently are not interconnected or are poorly connected. Densely welded ash-flow tuffs have physical characteristics similar to those of rhyolitic lava flows, and, like the lava flows, they have a wide range in water-yield potential, with interconnecting fractures affording the principal avenues for ground-water movement. Interstitial porosity and permeability of ash-fall and nonwelded ash-flow tuffs are greater than those of the rhyolitic lavas and densely welded tuffs. However, fractures are healed more readily in these relatively incompetent rocks, and secondary fracture porosity and permeability are much lower than those of the rhyolitic lavas and densely welded tuffs. The yield of water to wells from intervals of ash-fall and nonwelded ash-flow tuffs is low, and for this reason, from the hydrologic standpoint, these rocks are considered ideal media for mining of chambers within the saturated zone.

The depth to water under the eastern part of 
Pahute Mesa, within the limits of the Silent Canyon caldera, ranges from about 1,952 feet (alt $4,164 \mathrm{ft}$ ) in the western part to 2,350 feet (alt $4,685 \mathrm{ft}$ ) in the eastern part. In the extreme northwestern part of the Nevada Test Site, outside the caldera, the depth to water is about 850 feet (alt $4,700 \mathrm{ft}$ ).

The regional hydraulic gradient is to the southwest and south. It ranges from a low of about 25 feet per mile in the northeastern part of the caldera to 100 feet per mile in the western and southwestern parts; the average gradient is 50 feet per mile. The steeper gradients in the western and southwestern parts of the caldera correspond to an increase in the percentage of poorly permeable ash-fall tuff in the saturated zone.

The total underflow beneath Pahute Mesa is about 8,000 acre-feet per year; ground-water velocity ranges from 0.7 to 0.02 foot per day, or 20 to 750 years per mile. From Pahute Mesa, ground water moves southwestward and southward toward the Amargosa Desert through Oasis Valley, Crater Flat, and western Jackass Flats.

The chemical composition of the ground water bəneath Pahute Mesa can be related to the pattern of head changes with depth. In the eastern part of the caldera, rhyolitic lava flows and densely welded tuffs constitute 40 to 100 percent of the volcanic rock types in the upper 2,000 feet of the saturated zone, and head potentials decrease with depth. Water from drill holes where these conditions prevail is dominated by sodium and bicarbonate but contains appreciable amounts of calcium and magnesium. In the western part of the caldera, zeolitized bedded ash-fall and nonwelded ash-flow tuffs constitute the principal volcanic rock types in the saturated zone, and head potentials increase with depth. In water from holes drilled in these areas, sodium and potassium together are 90 to 99 percent of the total cations. The diminished amounts of calcium may be due to ion exchange when water from the rhyolite areas moves into areas that consist predominantly of zeolitized tuffs. Among the anions, bicarbonate is the most abundant, but sulfate and chloride contribute greater relative amounts in most water from the western part of the caldera.

The systematic and detailed hydraulic testing in deep drill holes at Pahute Mesa probably has never been done on a similar scale elsewhere in the world. The techniques and tools applied in the testing should have broad applications wherever deep-well testing is done. A typical hydraulic-testing schedule usually begins with geophysical logging. After completion of the geophysical logging, a pumping test is made to measure the gross yield of all the rocks ex- posed in the well bore. During the pumping, radioactive-tracer and temperature surveys are made to locate the zones where water enters the hole. After the pump has been pulled out of the hole, intervals in the drill hole are selected for a series of injection or swabbing tests. Injection or swabbing tests are made by adding known volumes of water to, or withdrawing known volumes of water from, intervals isolated with straddle packers and then observing the rate of decline or rise in water level resulting from this injection or withdrawal of water. From the rate of change in water levels with time, the yield of the various intervals at maximum drawdown can be computed. The yield of the intervals tested is stated as "relative specific capacity," expressed in gallons per minute per foot of drawdown and defined as the volume of inflow during a 1-minute interval divided by the difference between static water level and the mean water level during the 1-minute interval. Data obtained during these tests can also be used to determine the transmissivity of the aquifer immediately adjacent to the interval of borehole being tested. In addition, static water levels (formation pressures) of selected intervals are obtained.

Successful water injection and swabbing tests have been made in intervals isolated with straddle packers at depths to 9,000 feet. Temperatures at these depths have exceeded $79.4^{\circ} \mathrm{C}$.

Underground testing of nuclear devices at Pahute Mesa involves emplacement of devices far below the top of the saturated zone, commonly in mined chambers at the emplacement depth. During excavation of the chambers and preparations for detonation of the nuclear device, only a small influx of water can be tolerated. The intervals to be mined are selected in the least permeable rocks, on the basis of data collected during hydraulic testing of exploratory holes. Ash-fall and nonwelded ash-flow tuff which have been zeolitized or argillized are hydrologically the best rock types in which to construct the chambers. Intervals of 200 feet in exploratory holes having relative specific capacities less than $0.03 \mathrm{gpm}$ per foot of drawdown are considered most favorable. Those intervals having relative specific capacities ranging between 0.03 to $0.04 \mathrm{gpm}$ per foot of drawdown are considered marginal, and those greater than 0.04 should be mined only where the head is small. Rhyolite flows and densely welded tuff are not considered favorable rock types for mining of chambers. Although these indurated rocks may be impermeable immediately adjacent to the borehole, open water-bearing fractures a short distance from the borehole may be encountered during mining. 
Five chambers, with diameters ranging from 14 to 26 feet and heights ranging from 31 to 46 feet, have been mined successfully at depths as much as 2,600 feet below the top of the saturated zone. At each site an emplacement hole, usually 72 inches in diameter, was drilled near the exploratory hole. Drilling of the emplacement hole was interrupted several hundred feet above the interval proposed for mining. Casing with an outer diameter of 103/4 inches was tack-cemented, and a 97/8-inch hole was drilled and cored through the critical interval to permit geophysical logging and hydraulic testing. The exact intervals for mining were based on these hydraulic testing and geological data.

Early estimates of inflow to chambers were made to establish hydrologic safety limits for miners. Permeability was derived, approximately, from values of relative specific capacity, and estimates of inflow were graphed for chambers of different dimensions. Actual measurements during mining operations showed these estimates to be highly conservative. Presently, hydraulic-test data are used to compute values of transmissivity and storage coefficient for the tested interval. These data are applied by a type-curve method developed by Hantush (1961) for the constant-drawdown, leaky artesian inflow to a well to determine inflow to a chamber.

Measurements of water inflow to chambers show a decline of 30 to 45 percent of inflow during the initial 3 to 4 days. The decrease is very gradual after 1 week. Inflow rates to the five chambers mined at Pahute Mesa ranged from 10 to $214 \mathrm{gph} 1$ to 3 months after completion of chamber excavations and when inflow was virtually stable.

On the basis of data from hydraulic testing, areas favorable for drilling water-supply wells were determined. The greatest water yields generally were obtained from holes drilled in areas where fractured rhyolitic lava flows and densely welded tuffs predominate in the upper 2,000 feet of the saturated zone. A satisfactory supply of water can be obtained where these rocks comprise about 40 percent or more of the rock section. Where less favorable rocks occur in the saturated zone, satisfactory water-supply wells can be developed in areas of major faults, especially near the caldera boundary. South of Pahute Mesa the moat area of the Timber Mountain caldera complex is an excellent potential source of water supply.

\section{REFERENCES}

Blankennagel, R. K., 1967, Hydraulic testing techniques of deep drill holes at Pahute Mesa, Nevada Test Site: U.S. Geol. Survey open-file rept., Interagency Report Special Studies I-1, $50 \mathrm{p}$.
1968, Geophysical logging and hydraulic testing, Pahute Mesa, Nevada Test Site: Ground Water, v. 6, no. 4, p. 24-31.

Byers, F. M., Jr., Orkild, P. P., Carr, W. J., and Quinlivan, W. D., 1968, Timber Mountain Tuff, southern Nevada, and its relation to cauldron subsidence: Geol. Soc. America Mem. 110, p. 87-98.

Carr, W. J., 1964, Structure of part of the Timber Mountain dome and caldera, Nye County, Nevada, in Geological Survey Research 1964: U.S. Geol. Survey Prof. Paper 501-B, p. B16-B19.

Christiansen, R. L., and Lipman, P. W., 1966, Emplacement and thermal history of a rhyolite lava flow near Fortymile Canyon, southern Nevada: Geol. Soc. America Bull., v. 77, p. 671-684.

Christiansen, R. L., and Noble, D. C., 1965, Black Mountain volcanism in southern Nevada [abs.]: Geol. Soc. America Spec. Paper 82, p. 246.

Clebsch, Alfred, Jr., and Barker, F. B., 1960, Analyses of ground water from Rainier Mesa, Nevada Test Site, Nye County, Nevada: U.S. Geol. Survey open-file rept., TEI-763, $22 \mathrm{p}$.

Cooper, H. H., Jr., Bredehoeft, J. D., and Papadopulos, I. S., 1967, Response of a finite diameter well to an instantaneous charge of water: Water Resources Research, v. 3, no. 1, p. 263-269.

Dudley, W. W., Jr., 1970, Nonsteady inflow to a chamber within a thick aquitard, in Geological Survey Research 1970: U.S. Geol. Survey Prof. Paper 700-C, p. C206C211.

Eakin, T. E., and others, 1951, Contributions to the hydrology of eastern Nevada: Nevada State Engineer, Water Resources Bull. 12, $171 \mathrm{p}$.

Eakin, T. E., Schoff, S. L., and Cohen, Philip, 1963, Regional hydrology of a part of southern Nevada - a reconnaissance: U.S. Geol. Survey open-file rept., TEI-833, $40 \mathrm{p}$.

Hantush, M. S., 1961, Drawdown around a partially penetrating well: Am. Soc. Civil Engineers Proc., Jour. Hydraulics Div., v. 87, (HY4), p. 83-98.

Levorsen, A. I., 1954, Geology of petroleum: W. H. Freeman and Co., p. 398-406.

Lipman, P. W., Christiansen, R. L., and O'Connor, J. T., 1966, A compositionally zoned ash-flow sheet in southern Nevada: U.S. Geol. Survey Prof. Paper 524-F, 47 p.

Malmberg, G. T., and Eakin, T. E., 1962, Ground-water appraisal of Sarcobatus Flat and Oasis Valley, Nye and Esmeralda Counties, Nevada: Nevada State Engineer, Ground Water Resources, Reconn. Ser. Rept. 10, 39 p.

Moore, J. E., 1961, Records of wells, test holes, and springs in the Nevada Test Site and surrounding area: U.S. Geol. Survey open-file rept., TEI-781, 22 p.

Noble, D. C., Anderson, R. E., Ekren, E. B., and O'Connor, J. T., 1964, Thirsty Canyon Tuff of Nye and Esmeralda Counties, Nevada, in Short papers on geology and hydrology: U.S. Geol. Survey Prof. Paper 475-D, p. D24-D27.

Noble, D. C., Sargent, K. A., Mehnert, H. H., Ekren, E. B., and Byers, F. M., Jr., 1968, Silent Canyon volcanic center, Nye County, Nevada: Geol. Soc. America Mem. 110 , p. 65-75.

Orkild, P. P., 1965, Paintbrush Tuff and Timber Mountain Tuff of Nye County, Nevada, in Changes in stratigraphic nomenclature by the U.S. Geological Survey, 1964: U.S. Geol. Survey Bull. 1224-A, p. A44-A51. 
Orkild, P. P., Byers, F. M., Hoover, D. L., and Sargent, K. A., 1968, Subsurface geology of Silent Canyon caldera, Nevada Test Site, Nevada: Geol. Soc. America Mem. 110, p. 77-86.

Orkild, P. P., Sargent, K. A., and Snyder, R. P., 1969, Geologic map of Pahute Mesa, Nevada Test Site and vicinity, Nye County, Nevada: U.S. Geol. Survey Misc. Geol. Inv. Map I-567, 5 p.

Ratté, J. C., and Steven, T. A., 1967, Ash flows and related volcanic rocks associated with the Creede caldera, San Juan Mountains, Colorado: U.S. Geol. Survey Prof. Paper 524-H, $58 \mathrm{p}$.

Ross, C. S., and Smith, R. L., 1961, Ash-flow tuffs - Their origin, geologic relations, and identification: U.S. Geol. Survey Prof. Paper 366, $81 \mathrm{p}$.
Schoff, S. L., and Moore, J. E., 1964, Chemistry and movement of ground water, Nevada Test Site: U.S. Geol. Survey open-file rept., TEI-838, $75 \mathrm{p}$.

Thordarson, William, 1965, Perched ground water in zeolitized-bedded tuff, Rainier Mesa and vicinity, Nevada Test Site: U.S. Geol. Survey open-file rept., TEI-862, $90 \mathrm{p}$.

Winograd, I. J., Thordarson, William, and Young, R. A., 1971, Hydrology of the Nevada Test Site and vicinity, southeastern Nevada: U.S. Geol. Survey open-file rept., $429 \mathrm{p}$.

Young, R. A., 1972, Water supply for the Nuclear Rocket Development Station at the U.S. Atomic Energy Commission's Nevada Test Site: U.S. Geol. Survey WaterSupply Paper 1938, 19 p.

* U.S. GOVERNMENT PRINTING OFFICE: 1973-515-659/22 
